\title{
JOHN SALMOND AND NATIVE TITLE IN NEW ZEALAND: DEVELOPING A CROWN THEORY ON THE TREATY OF WAITANGI, 1910-1920
}

\author{
Mark Hickford ${ }^{*}$
}

This extended essay argues for a new approach towards the writing of constitutional histories of the Crown within New Zealand. It looks specifically at the conceptions of the relationship between the Treaty of Waitangi, the common law and customary interests that the Crown and its legal advisors actually employed in internal deliberation and external positioning. In looking at the processes for articulating the Crown's preferred legal position during John Salmond's tenure as SolicitorGeneral, this article notes the overwhelming prevalence of statute and Treaty-based conceptions in law (as well as areas of historical change and discontinuity). Common law approaches emerged in the later twentieth century through newly minted theories or doctrines of aboriginal title but were never regarded as distinct options by the historical actors themselves. The concern of this article is with how those actors - most notably Salmond - conceived, acted upon and adapted their perception of the Crown's constitutional obligations to Màori. In mapping the course of a Crown legal "register" or way of speaking about native title and the Treaty of Waitangi, the essay aims to reveal the rich and contested nuances of the approaches assumed by the legal advisors to the Crown on the question of the Treaty from 1910 until 1920 and its relevance to a governmental outlook on customary property.

* Crown Counsel, Crown Law Office, PO Box 2858, Wellington, New Zealand, mark.hickford@crownlaw.govt.nz (Adjunct Lecturer, Victoria University of Wellington Law School; senior consultant to the Law Commission on secondment from the Crown Law Office, January 2007-April 2008). This essay is based on my reflections as chair of the Salmond and Native Land session of The Salmond Symposium at Victoria University of Wellington Law School on 19 August 2006. I thank the organisers of the conference, Geoffrey McLay and Shaunnagh Dorsett, for inviting me to participate. The views expressed in this paper are personal to the author and not necessarily those of the Crown Law Office. I am grateful for the comments of my colleague Dr Damen Ward, Associate Crown Counsel, Dr Ashley Gould, Consultant Historian, J Brent Parker, and Dr Paul G McHugh of Sidney Sussex College, University of Cambridge. 


\section{INTRODUCTION - AN APPROACH TOWARDS WRITING CONSTITUTIONAL HISTORIES OF THE CROWN AND THE TREATY OF WAITANGI}

I intend to demonstrate that John Salmond as Solicitor-General endeavoured to develop a particular form of Crown "register" on the Treaty of Waitangi and "native title" in New Zealand through the ordinary courts and internally within government itself. I use the term "register" not in the sense of a physical record or volume but that of a particular variety of language, idiom or vocabulary: a specific way of seeing and talking about something. It was communicable to others both within and outside of the executive government although only the tangible textual traces of it remain extant in the record. This article contends that the Crown approach during the tenure of Salmond as Solicitor-General from 2 February 1910 until his elevation to the judiciary in May 1920 was, in essence, a Treaty of Waitangi-centred account of the source of claims to customary property rights rather than a theoretical position premised upon or determined by the common law. In these circumstances, "native title" was not perceived to be a common law species of right or interest at all. It was treated as a class of rights emerging out of the Treaty of Waitangi (initially entered into at Waitangi on 6 February 1840). "Rights" expressed in the Treaty were not received as legal rights except insofar as they had been accorded discrete recognition in legislation. This was not merely an issue of "focus", as one commentator has suggested. ${ }^{1}$ The legal analysis of advisors to the Crown stressed the centrality of the statutory recognition of such potential claims as opposed to the possibility of an independently justiciable source in common law. Such a perspective was thought to enjoy reasonable sustenance from existing judicial authority, including the advice of the judicial committee of the Privy Council in Nireaha Tamakiv Baker. ${ }^{2}$

Frame's pioneering account has glimpsed the possibility of this interpretation faintly and en passant. ${ }^{3}$ But, for the Crown Law Office, this approach was sustained via an earnestly held legal and theoretical view of the Treaty of Waitangi as a source of political claims to "rights". These

1 The argument presented here is therefore at variance with Professor Alex Frame's assertion in Salmond: Southern Jurist (Victoria University Press, Wellington, 1995) 126 ("Rather like an Escher drawing, the question is one of focus - is one looking at customary rights as the structure on which statute superimposes, or is one looking at the statute as the structure whose interstices accommodate customary rights? Salmond's position is as modern as Mabo [referring to Mabo v Queensland (No 2) (1992) 175 CLR 1 (HCA)]...", a point with which I would respectfully beg to differ); and the implication in note 54 of that text, to the effect that the late twentieth century approach to the common law doctrine of aboriginal rights was broadly comparable to that employed on behalf of the Crown during John Salmond's tenure as Solicitor-General. The distinction is subtle but is, nevertheless, critical to appreciating, and historicising, in an accurate fashion, the possible legal strategies of the Crown at this time and the policy rationale of the executive, as well as the concrete consequences for its official conduct. In this sense, the argument agrees with Richard Boast's article in this volume.

$2 \quad$ Nireaha Tamaki v Baker [1901] AC 561 (PC), 70 LJPC 66.

3 Frame Salmond: Southern Jurist, above n 1, 126, 127-128 (and note 68). 
rights were to be expressed in the legal expression of policy preferences promoted by the Crown-inParliament - legislation. This article builds upon (and, in significant respects, occasionally disagrees with) Boast's important work, ${ }^{4}$ as well as that of White, ${ }^{5}$ but seeks to outline the legal-historical nuances of the approach of the Crown and to reveal the pressures placed upon it. In doing so, the critical object of this paper is to tease out the reasoning underlying a Crown legal "register" on the Treaty of Waitangi internal to government and communicable in litigation or in correspondence to those beyond the executive branch, to chart the process of its development together with its rationale, and to explore its strategic use. Salmond ought not to be faulted for the theoretical stance that he developed. It was a perspective that was at once understandable (albeit admittedly contestable) in light of a plausible interpretation of the state of judicial authority within New Zealand and informed by a sense of the preferred, if disputed, line of policy coursing through native land legislation. The following account reveals a rich vein of dispute and discussion on the Treaty of Waitangi in a critical part of New Zealand's legal and constitutional history. It was a complicated and occasionally fraught conversation with consequences in legislation and policy well into the twentieth century. If this is not appreciated, then much of that history will be misconstrued and the significance of the contribution of Paul McHugh and others in the 1980s misunderstood.

The focus on a "register" or particular form of language and idiomatic expression concerning an issue within public law ought not to be restricted to the judicial engagement with executive action in litigation or to other external features of governmental behaviour (such as the public statements of Ministers). Method in legal history must be subtler than simply analysing the officially reported versions of court decisions - the fossilised remnants of complicated and often lively contexts. Much of what the Crown does is not the subject of litigation. Much of what passes for public law occurs within government. In this vein, the analysis ought to be extended to observable forms of internal control, persuasion and behaviour within the executive branch of government, including minutes, correspondence and sometimes contestable legal opinion writing and the use of legal theory and strategy to co-ordinate (even if unsuccessfully) governmental approaches to certain subjects. ${ }^{6}$ Law

4 See Richard Boast "The Foreshore" Waitangi Tribunal, Rangahaua Whānui National Theme $Q$ (Waitangi Tribunal, Wellington, 1996) 35 et seq.

5 B White "Inland Waterways: Lakes" Waitangi Tribunal, Rangahaua Whānui National Theme $Q$ (Waitangi Tribunal, Wellington, 1998).

6 As Terence Daintith and Alan Page suggest in their sophisticated contemporary study The Executive in the Constitution: Structure, Autonomy, and Internal Control (Oxford University Press, Oxford, 1999). "It was [J G A] Pocock above all who taught my generation to think of the history of political theory [or of legal history I would add] not as a study of allegedly canonical texts, but rather as a more wide-ranging investigation of the changing political languages in which societies talk to themselves" (Q Skinner Liberty Before Liberalism (Cambridge University Press, Cambridge, 1998) 105)). Analysis of forms of language deployed in practice should be complemented by a "sense of the complex ways in which individuals respond to, assimilate and reshape the materials of their intellectual milieux": see J W Burrow A Liberal Descent: Victorian Historians and the English Past (Cambridge University Press, Cambridge, 1981), 5. Also, J G A Pocock Politics, Language and Time: Essays on Political Thought and History (Chicago 
was, of course, a resource that government actively deployed but, even if influential, it need not have been determinative in any given instance of policy-formulation.

\section{CLAIMING IN CUSTOM - "NATIVE TITLE IS NOT IN ITSELF ENTITLED TO LEGAL RECOGNITION"}

Under Salmond, the attempt to produce a persuasive Crown register or way of seeing and talking about the Treaty of Waitangi and what was referred to, variously, as "native title" or "rights of native ownership" proved somewhat chimerical at least in the courts if not within government. Internally the behaviour of departments might not necessarily accord with this preferred legal stance but it could supply the impression of legal unity to external audiences, such as the courts, through the consistent legal representation of the Crown Law Office. In this article, I suggest that the impression of legal unity and continuity, casually assumed as real, needs to be unpacked with care. The faultlines and discontinuities in, or changes to, the Crown's legal-policy approaches over time need to be explored. Within the Crown Law Office, Salmond principally enjoyed the assistance of two Assistant Law Officers (who might describe themselves as "Crown solicitors") namely Hubert Ostler and E Redward. ${ }^{7}$ Also invited to contribute on occasion were Crown solicitors based in various local or regional centres. Notably, Salmond's approach to seeking judicial recognition of an internally consistent and coherent Crown theory on these issues succeeded in the Supreme Court in Waipapakura $v$ Hempton $^{8}$ in regards to Māori fishing rights, but failed in Tamihana Korokai v Solicitor-General ${ }^{9}$ in respect of lakes. Both of these cases would represent waypoints for the Crown's preferred legal stance during the remainder of Salmond's period of service as SolicitorGeneral. In addition, as will be explored in the final section of this essay, that legal approach would persevere politically and ultimately, find statutory expression in 1922, as a result of a political outof-court settlement over fourteen of the so-called "Rotorua district" or "Arawa district" lakes in the central North Island of New Zealand.

Salmond's underlying conception of customary tenure was that it derived from the Treaty of Waitangi and had no independent source of recognition or existence in common law. Its legal recognition occurred via statute, as the Treaty obligations were political or moral claims upon the Crown. This was most cogently expressed as a general proposition in legal advice in 1917. Writing

University Press, Chicago, 1989) 23-30; J Tully (ed) Meaning and Context: Quentin Skinner and His Critics (Princeton University Press, Princeton, 1988); Q Skinner "Interpretation and the Understanding of Speech Acts" in Skinner Visions of Politics: Volume I, Regarding Method (Cambridge University Press, Cambridge, 2002) 103-127.

7 The title "Crown counsel" was not yet used.

8 Waipapakura v Hempton (1914) 33 NZLR 1065 (Full Court of the Supreme Court).

9 Tamihana Korokai v Solicitor-General (1912) 32 NZLR 321 (CA). 
to the Under-secretary of Lands, Thomas N Brodrick, ${ }^{10}$ on the question of Māori customary tenure in submerged land, Salmond explained that, "[n]ative customary title depends for its legal existence on the Treaty of Waitangi as recognized and validated as a ground of legal title by the successive Acts dealing with Native land." 11 While counsel in the Law Drafting Office in 1909 Salmond conceived the nature of property rights claims in custom as "merely a moral claim, dependent upon the good will of the Crown, and not recognizable or enforceable at law". ${ }^{12}$ In 1910 a substantially altered version of Salmond's explanatory memorandum initially prepared to accompany the Native Land Bill in 1909 was printed with a published version of the Native Land Act 1909. This later memorandum of 1910, issued by Salmond in his capacity as Solicitor-General, described customary land as follows: "As against the Crown it is not a legal title at all, but a mere moral claim under the Treaty of Waitangi to obtain a Crown grant". ${ }^{13}$ Thus, importantly, "native title" was not received as a common law species of right at all. Elsewhere within that particular explanatory note, Salmond would characterize "customary land" as "land in respect of which the ancient customary Native title, as recognized and guaranteed by the Treaty of Waitangi, has not yet been extinguished". ${ }^{14} \mathrm{He}$ elaborated that, "[s]uch land, since it has not been Crown-granted, remains vested in the Crown, subject, however, to the customary title of the Natives and to their right to have the customary title transformed into a freehold title by the Native Land Court". 15 "Native title is not in itself entitled to legal recognition", went the Crown Law Office argument prepared for the Native Land Court hearing in the Rotorua Lakes case. ${ }^{16}$

10 Thomas Noel Brodrick (1855-1931) became Under-secretary of Lands in 1915: see Ashley Gould, "Thomas Noel Brodrick" in The Dictionary of New Zealand Biography: Volume III - 1901-1920 (Auckland University Press and Department of Internal Affairs, Wellington, 1996) 68-69.

11 Salmond, Solicitor-General, to Under-secretary of Lands (11 June 1917) Crown Law [Office] ("CL") 174/2, Archives New Zealand, Wellington.

12 Salmond "Native Land Bill [1909]: Memorandum. Notes on the History of Native-land Legislation", Number 87-3, Bill Books, 1909, 1, Parliamentary Counsel Office, Wellington ["Native Land Bill (1909)"]. David V Williams of the University of Auckland located an unprinted typescript of this memorandum in the University of Auckland library (NZGC 333.099517), which has been published in appendix C of H Bassett, R Steel and David V Williams Māori Land Legislation Manual (Crown Forestry Rental Trust, Wellington, 1994).

13 "The Native Land Act, 1909 - Introduction (Memorandum by the Solicitor-General)" in The Native Land Act, 1909, with Explanatory Memorandum, Index to Act, Rules of Court, Regulations, Orders in Council defining Districts, etc (issued by the direction of the Hon James Carroll, Native Minister) (John MacKay, Government Printer, Wellington, 1910) xi.

14 Ibid, ix.

15 Ibid

16 Crown Law Office argument Rotorua Case undated, 1918(?) 6, CL174/2 Archives New Zealand, Wellington. 


\section{SALMOND AND THE ENFORCEABILITY OF NATIVE TITLE AGAINST THE CROWN - SALMOND'S OUTLOOK IN 1909}

This sort of analysis coincided with the plausible response of Salmond to the advice of the judicial committee of the Privy Council in 1901 in Nireaha Tamaki v Baker. ${ }^{17}$ In 1909 Salmond queried the effect of Nireaha Tamaki v Baker on the place of customary interests at law. "Whether by virtue of [the] legislative recognition [the right of Māori to their customary lands under the Treaty of Waitangi] has now become a legal right enforceable against the Crown has never been decided, and was left an open question by the Privy Council in Nireaha Tamaki v Baker". ${ }^{18}$ This observation of Salmond in the explanatory note was subtle, as the question of legal enforceability that he was ruminating on amounted to whether the customary title already acknowledged statutorily could be pursued in the courts against the Crown per se, as opposed to distinct or identifiable servants of the Crown acting in accordance with assumed statutory authority. In this particular sense, the perceived doubtfulness as to the enforceability of statutorily-recognised customary land against the Crown ("His Majesty the King") was resolved through a policy preference in the form of section 84 of the Native Land Act 1909. Section 84 said that, "Save so far as otherwise expressly provided in any other Act the Native customary title to land shall not be available or enforceable against His Majesty the King by any proceedings in any Court or in any other matter." This critical point concerning Salmond's view of the legal situation in 1909 ought not to be overlooked although certain scholars have sought to imagine a rather broad disjunction between the official stance of Salmond on native title and underlying custom and that of their Lordships in Nireaha Tamaki $v$ Baker. ${ }^{19}$ In that case on appeal, Lord Davey, in referring to section 2 of the Land Claims Ordinance of 1841 , observed that this instrument of the legislative council had not conferred title on the Crown but had declared the title of the Crown in "all unappropriated lands" within the colony of New Zealand, to be subject to the "right and necessary occupation and use thereof by the aboriginal inhabitants of the said Colony". ${ }^{20}$ Yet, crucially, such recognition in an ordinance "would not of

17 Nireaha Tamaki v Baker, above $\mathrm{n} 2$.

18 Salmond "Native Land Bill [1909]", above n 12. Incidentally, the version in the Bill Books referred to as 87-1 features a handwritten marginal note of unknown authorship against the passage cited here stating: "But see Te HeuHeu v Aotea 1941 NZLR" (referring to the important advice of the Judicial Committeee of the Privy Council in Hoani Te Heu Heu Tukino v Aotea District Land Board [1941] AC 308 (PC); [1941] NZLR 590 (PC)). See Alex Frame "Hoani Te Heuheu's Case in London 1940-1941: An Explosive Story" (2006) 22 NZULR 148.

19 On this count, for instance, the analysis here departs from David V Williams "Fame and Infamy - A Tale of Two Men of the Law in Colonial New Zealand" in H Foster and B Berger (eds) History's Living Legacy: Essays on Colonial Legal Culture in Canada, Australia and New Zealand (University of British Columbia Press, Vancouver, forthcoming) and David V Williams "Wi Parata is Dead, Long Live Wi Parata" in A Erueti and C Charters (eds) Maori Property Rights and the Foreshore and Seabed: The Last Frontier (Victoria University Press, Wellington, 2007) 37-39.

20 Nireaha Tamaki v Baker, above n 2, 567 Lord Davey. 
itself $\ldots$ be sufficient to create a right in the native occupiers cognizable in a Court of Law". ${ }^{21}$ The speech of Lord Davey then traversed the range of native land legislation, together with the five sections of the brief Native Rights Act 1865. ${ }^{22}$ These were important, in that a role for the courts on the issue of native title was directly engaged via statute. As his Lordship appreciated, section 5 of the Native Rights Act 1865 provided that:

In any action in which the title to or any interest in any such land is involved the Judge before whom the same shall be tried shall order that any issue or issues in such action in which such title or interest is involved whether they be issues of fact or of Maori Custom or Usage shall be tried in the Native Lands Court and the Judge of the Native Lands Court before whom the same shall be tried shall return the verdict or judgment as the case may be into the Supreme Court and such verdict or judgment shall be taken as conclusive both as to fact and as to the Maori Custom or Usage and shall be dealt with by the Supreme Court in the same manner and shall have the same effect as the verdict of a jury in the Supreme Court.

In disagreeing with the reasoning of the Chief Justice, James Prendergast, in the decision of the Supreme Court in Wi Parata v Bishop of Wellington, ${ }^{23}$ that there was no Māori customary law of which an ordinary court of law could take cognisance, the judicial committee carefully referred to section 5 of the Native Rights Act 1865. Lord Davey perceived that provision as plainly contemplating that cases might arise in which a court of inherent jurisdiction - the Supreme Court would have to consider the relevant title or interest in native land. In such a situation, as Lord Davey acknowledged, the Supreme Court judge was obliged to remit any such issue to the Native Land Court. ${ }^{24}$ The Native Land Court's "verdict or judgment" would be "taken as conclusive both as to fact and as to the Maori Custom or Usage". Thus, Lord Davey advised that, "[i]f necessary for the ascertainment of the appellant's alleged rights, the Supreme Court must seek the assistance of the Native Land Court; but that circumstance does not appear to their Lordships an objection to the Supreme Court entertaining the appellant's action". ${ }^{25}$ It was admitted, then, that the Native Land Court, a creature of statute in itself, had been accorded the exclusive legislative authority to investigate customary interests in land.

21 Ibid (emphasis added).

22 Native Rights Act 1865, 29 Vict, c 11 (26 September 1865) (NZ). Its long title reads: "An Act to declare that the Māoris shall be deemed to be natural-born subjects of Her Majesty and to declare that the jurisdiction of the Queen's Courts of Law extends over the persons and properties of all Her Majesty's subjects within the Colony".

23 Wi Parata v Bishop of Wellington (1877) 3 NZ Jur (NS) SC 72.

24 Nireaha Tamaki v Baker, above n 2, 577 Lord Davey.

25 Ibid, 578 
The Privy Council saw no basis for doubting the correctness of the decision in Wi Parata $v$ Bishop of Wellington (Wi Parata) on the fine but significant legal point that the Supreme Court had no jurisdiction by a writ of scire facias or any other proceeding to annul a Crown grant for any matter not appearing on the face of the grant. It also agreed that the issue of a Crown grant implied a declaration on the part of the Crown that the customary native title had been extinguished at law. ${ }^{26}$ That said, such a legal conclusion suggested that, "it [was] all the more important that natives should be able to protect their rights (whatever they are) before the land is sold and granted to a purchaser" pursuant to statutory authorisation under the Land Act 1892. ${ }^{27}$ Section 136 of the Land Act 1892 outlined a process for offering up so-called "rural lands" for sale. ${ }^{28}$ The information before the Judicial Committee indicated that the Native Land Court had already investigated and ascertained the title of the appellant amongst others to the Mangatainoka block, and issued an order dated 13 September 1871 pursuant to the Native Lands Act of $1865 .{ }^{29}$ On 13 July 1893 the respondent by public notice offered a parcel of land named Kaiparoro, comprising some 20,000 acres, containing parts of two blocks referred to as Kaihinu No 1 and Kaihinu No 2, as well as a disputed area of 5,184 acres, the title to which was subject to contest in the action under appeal to the judicial committee of the Privy Council. There was a contest as to whether the 5,184 acres at issue formed part of the Mangatainoka block or were included within the otherwise adjacent Kaihinu No 2 block. The Law Lords expressed "no opinion on the question which was mooted in the course of argument, whether the native title could be extinguished by the exercise of the prerogative, which does not arise in the present case". ${ }^{30}$

The judicial committee was, nevertheless, cautious as to whether the appellant could not sue upon his asserted native title against the "Crown itself" 31 as opposed to the respondent, the Commissioner of Crown Lands in the Wellington district (Mr Baker). It was this non-committal

26 Ibid, 579. In that passage, while acknowledging that the obiter dicta in Wi Parata proceeded beyond what was necessary to that specific decision, Lord Davey continued that, "their Lordships have already commented on the limited construction and effect attributed to the $3^{\text {rd }}$ section of the Native Rights Act, 1865, by the Chief Justice in [Wi Parata]. As applied to the case then before the Court, however, their Lordships see no reason to doubt the correctness of the conclusion arrived at by the learned judges" (emphasis added).

27 Ibid.

28 Section 136 of the Land Act 1892 stated that, "The Governor may from time to time, by notification in the Gazette, declare that any rural land within the colony, including land now open for selection, but not being lands now or hereafter to be open under Parts V or VI of this Act, shall be open for sale or selection in the manner and upon the conditions mentioned in this Part of this Act. Before gazetting any such notification the Governor shall require the Surveyor-General to report upon the nature, class, and value of such land."

30 Ibid, 580.

31 Ibid, 578. 
caution that explains Salmond's interpretation of Nireaha Tamaki v Baker. "[T]here may be difficulties in [the] way [of the appellant relying on native title] (whether insurmountable or not it [was] unnecessary to say); but for the reasons already given that question, in the opinion of their Lordships, does not arise in the present case". ${ }^{32}$ In short, Lord Davey had already concluded that a suit could be brought against the respondent party, the Commissioner of Crown Lands in the Wellington district, as the "respondent's authority to sell on behalf of the Crown was derived solely from the statutes [including the Land Act 1892], and is confined within the four corners of the statutes". ${ }^{33}$ A servant of the Crown (not the Crown per se) had performed the act complained of. In these circumstances, the "fallacy of the judges of the Court of Appeal in New Zealand", indicated Lord Davey, was "to treat the respondent as if he were the Crown, or acting under the authority of the Crown for the purpose of this action". ${ }^{34}$ In this sense, the judicial committee was pronouncing on a principle that had acquired acceptance within the United Kingdom. Thus, while the orthodox viewpoint that the Crown in the person of the monarch could do no wrong still held sway, it was increasingly accepted that a servant of the Crown could be legally liable for an act. ${ }^{35}$ A leading text on proceedings by and against the Crown published in 1908 would refer to the advice of the Judicial Committee in Nireaha Tamaki $v$ Baker as an additional, illustrative authority for this developing legal principle. ${ }^{36}$ The reported submissions on behalf of the appellant in Tamaki emphasized that the question on appeal was whether the Supreme Court had jurisdiction to determine the legality of the acts of the respondent, specifically whether they were duly authorised by section 136 and 137 of

32 Ibid.

33 Ibid, 595 (emphasis added). For an interesting albeit brief overview of the judiciary and the Crown in the United Kingdom at this time, see R Stevens "Government and the Judiciary" in Vernon Bogdanor (ed) The British Constitution in the Twentieth Century (Oxford University Press for the British Academy, Oxford, 2003) 335-338; and J Jowell "Administrative Law" ibid, 374-376.

34 Nireaha Tamaki v Baker, above n 2, 575 Lord Davey.

35 The Judicial Committee cited Musgrave v Pulido (1879) 5 App Cas 102 and Tobin v Regina (1864) 16 CB (NS) 310. For current discussions of Crown immunity and Ministerial or official non-immunity, see Sir William Wade "The Crown, Ministers and Officials: Legal Status and Liability", and other contributions in Maurice Sunkin and Sebastian Payne (eds) The Nature of the Crown: A Legal and Political Analysis (Oxford University Press, Oxford, 1999).

36 See George Stuart Robertson The Law and Practice of Civil Proceedings By and Against the Crown and Departments of the Government with Numerous Forms and Precedents (Stevens and Sons Limited, London, 1908) 10, 639. "'The authority of the Crown' as used in this proposition, includes also the authority of any Government Department or official to whom the Crown has deputed its powers in that behalf ... See also Rogers v Rajendro Dutt (1860) 13 Moo PC 209; and Nireaha Tamaki v Baker, [1901] AC 561, 575; 70 LJPC 66" (Robertson, 639). Also, "It must be remembered that 'it is for the officers of the Crown to make out clearly the prerogative, in any case where they claim to be on a different footing from the subject as regards procedure in any litigation' (Attorney-General to the Prince of Wales $v$ Crossman, (1866) LR $1 \mathrm{Ex}$ 381, 386; 4 H \& C 568, 575; 35 LJ Ex 215. See also Nireaha Tamaki v Baker [1901] AC 561, 575; 70 LJPC 66" (Robertson, 10). 
the Land Act $1892 .{ }^{37}$ The judicial committee answered that submission in the affirmative. Accordingly, when the matter of Tamihana Korokai v Solicitor-General materialised in 1910 in the wake of the enactment of the Native Land Act 1909, Salmond was alive to the possibility of the action raising "the question left undecided by the Privy Council in Nireaha [sic Tamaki] v Baker, whether the Native title is available or enforceable against the Crown". ${ }^{38} \mathrm{He}$ was also acutely aware that statutes did not bind the Crown unless they expressly said so. As will be seen in the next section, he would be disappointed. Nevertheless, the legislative source for legal recognition was tightly woven into a view that the Native Land Court, a creature of statute itself, was the proper repository for the hearing of native title claims.

\section{PRESENTING A CROWN APPROACH ON THE TREATY OF WAITANGI AND NATIVE TITLE IN THE COURT OF APPEAL (1912) AND SUPREME COURT (1914)}

In Tamihana Korokai in 1912 the Court of Appeal in Wellington merely held in a case-stated proceeding, that it was the duty of the Native Land Court to hear and adjudicate a claim to Māori customary proprietorship to the bed of Lake Rotorua. Conversely, Māori had the correlative right to make an application to the Native Land Court for the investigation and ascertainment of title to customary land pursuant to section 90 of the Native Land Act 1909. The term "customary land" in section 2 of the Native Land Act 1909 denoted "land which, being vested in the Crown, is held by Natives or the descendants of Natives under the customs and usages of the Māori people". ${ }^{39}$ The solicitors for the plaintiff were the legal firm of Earl and Kent in Auckland. The agent for these solicitors was the firm of Chapman, Skerrett, Wylie and Tripp in Wellington. Salmond and Ostler represented the Crown. Judgment on the case stated was delivered in the Court of Appeal on 7 October 1912. "I am of [the] opinion", said the Chief Justice, Sir Robert Stout, "that the Native Land Act recognizes that Natives have a right to their customary titles." ${ }^{40}$ In December 1909 the litigation was initially brought by way of ordinary statement of claim in the Supreme Court (Northern District). Eventually it proceeded under rule 245 of the Code of Civil Procedure on a special case stated basis with a view to inviting the court to pronounce on questions of law agreed amongst the parties that might, in effect, render the need for subsequent legal and evidential findings

37 Nireaha Tamaki v Baker, ibid, 564 Lord Davey.

38 Salmond, Solicitor-General, to J A Tole, Crown Solicitor, Auckland (5 February 1910) Crown Law Office Case 84 .

39 John William Tate has closely explored the text of the judicial opinions in Tamihana Korokai $v$ Solicitor-General in his survey "Tamihana Korokai and Native Title: Healing the Imperial Breach" (2005) 13 Waikato LR 103 ["Tamihana Korokai and Native Title"]. Yet I explore the context of this decision in detail by reference to the Crown Law Office proceedings and correspondence file, as well as the subsequent litigation in Waipapakura v Hempton and in the Native Land Court, and consider the Crown stance on the Treaty of Waitangi and native title.

40 Tamihana Korokai v Solicitor-General, above n 9, 345. 
irrelevant. In other words, it might obviate the need for the litigation to proceed to the judicial phase at first instance in the wake of a ruling on certain generic legal questions. ${ }^{41}$ Thus, a number of discrete questions were posed by way of consent between the parties. The case stated also included a number of agreed positions of fact. For instance, it was agreed that Lake Rotorua was approximately seven and a half miles in length and six miles in breadth. In addition, it was agreed that Lake Rotorua was "navigable throughout the greater part of its extent, the larger part being between forty feet and eighty feet in depth".

Delving into the papers for the case stated reveals the shape of Salmond's outlook in 1912. A key query was presented as paragraph 26 (b) of the special case stated. It asked "whether the bed of the Lake [was] Native customary land in respect of which a freehold order can be made by the Native Land Court". The succinct handwritten comment of Salmond appearing in the margin of the Crown Law Office's copy of the document simply stated "no jurisdiction to determine". ${ }^{42}$ On this score, Salmond's argument as to the lack of jurisdiction of the Native Land Court failed in the Court of Appeal.

Several questions in the special case directly raised the possibility that the Supreme Court had jurisdiction itself to entertain claims of "Native customary land" against the Crown. Salmond's response revealed disagreement with the possibility of action in the ordinary courts on native title interests in land. He recorded a "no" against paragraph 26(e): "Is Native customary title a ground on which any action can be instituted in this Court, whether for a declaration of title or for any other relief?" This rather assured and straightforward negative response in 1912 was apparently at variance with the implication (it is little more than that) from correspondence of 23 December 1909 that Salmond had forwarded to Charles Skerrett KC, a partner in the legal firm Chapman, Skerrett,

41 This resort to a case stated procedure would be an approach that the Crown would agree, in conjunction with other litigant parties, in Attorney-General v Ngāti Apa [2002] 2 NZLR 661 (HC); Attorney-General v Ngāti Apa [2003] 3 NZLR 643 (CA), the proceedings in which the first two questions of law posed were as follows: "What is the extent of the Māori Land Court's jurisdiction under Te Ture Whenua Māori Act [1993 (the Māori land legislation)] to determine the status of foreshore and seabed and the waters related thereto?" and "Does the law of New Zealand recognise any Māori customary title to all or any part of the foreshore?" It was also deployed In re an Application for Investigation of Title to the Ninety Mile Beach (Wharo Oneroa a Tohe) [1960] NZLR 673 (SC), dealt with on appeal in In re the Ninety-Mile Beach [1963] NZLR 461 (CA). The first question in the case stated in Re an Application for Investigation of Title to the Ninety Mile Beach (Wharo Oneroa a Tohe) was: "Does the jurisdiction of the Maori Land Court conferred by Section 161 of the Maori Affairs Act 1953 to investigate the title to customary land and to issue freehold orders in respect thereof extend to the investigation of title to and the issue of freehold orders in respect of land lying between mean high water mark and mean low water mark, which was at the time of the cession of New Zealand to Her Majesty the Queen under the Treaty of Waitangi owned and occupied by Maoris according to their customs and usages?"

42 Tamihana Korokai v Solicitor-General "Special case stated pursuant to Rule 245" 13, Crown Law Office Case 84, Wellington. 
Wylie and Tripp in Wellington. ${ }^{43}$ There was, however, some subtlety to the legal stance of the Crown. Salmond's letter conveyed the undertaking of James Carroll, the Native Minister in the Liberal Ministry of Joseph Ward, James Carroll, on behalf of that government that the Crown would not use what ultimately became section 84 of the Native Land Act 1909 to "raise any objection to the determination by the Supreme Court of the questions to which you refer, so long as you ask for nothing more than a declaration as to the legal position of the lands in question". ${ }^{4}$ This was clearly premised on the view that the sought-after "declaration" would accord no substantive immediate relief enforceable at law against the Crown or other parties. That enforceability (as opposed to the cognisability of native title) would arise once the Native Land Court investigated the title and issued orders, if any. Skerrett's letter of 22 December 1909, anticipating the imminent passage of the Native Land Bill 1909, had foreshadowed this sort of response as a result of meeting Salmond. ${ }^{45}$ Although Skerrett entertained some personal doubt whether clause 84 would have the desired effect, he recognised Salmond's advice that it was too late in the legislative track of the Bill to secure any amendments. Salmond, still counsel to the Law Drafting Office at this stage, also advised Skerrett that in the event of the Supreme Court deciding that "Native customary title exists in respect of those lands, it will then be for the Government to decide in its discretion whether it will allow proceedings for the issue of freehold orders to be instituted in the Native Land Act". ${ }^{46} \mathrm{He}$ added that, "if such proceedings are prohibited under Clause 100, the matter will become one for legislation instead of for the law Courts". ${ }^{47}$ The solicitors for the plaintiff were certainly on notice that resort to legislation was within the contemplation of the Government, were the Supreme Court to decide that "the Native customary title exists in respect of those lands". ${ }^{48}$ The Crown would then consider whether to prevent the Native Land Court from entertaining proceedings for the issue of freehold orders. The member of the House of Representatives for the Eastern Maori electorate,

43 Once appointed, King's Counsel were permitted to continue practice as solicitors at this time. Refer to the biographical note for Charles Skerrett by Barton in The Dictionary of New Zealand Biography, above n 10, 476.

44 Salmond, Law Drafting Office, to Charles Skerrett (23 December 1909) Crown Law Office Case 84A, Wellington.

45 Skerrett to Salmond (22 December 1909) AAMK 869, box 84b 5/13/242, pt 4, Arawa Lakes 1904-1925, Archives New Zealand, Wellington: "I quite recognise the position and desire to place on record what was intended to be effected by ... clause [84] so that the Counsel for the Crown may be instructed not to take up the position, in the cases in which I am interested, that there is any objection to the Supreme Court declaring the existence of a customary right if it is not sought to actively enforce that right against the Crown."

47 Ibid. 
Āpirana Ngata, received a comparable assurance. ${ }^{49}$ Frame has commented on this communication in some detail. ${ }^{50}$

In answer to paragraph 26(f) of the special case stated - "What remedy have the Natives in respect of their rights preserved by the Treaty of Waitangi [?]" - Salmond's handwritten note in the margin read "in the Native Land Court - freehold order". On the position he had taken on paragraph 26(f) of the special case stated, Salmond implicitly received a favourable response from the Court of Appeal in Tamihana Korokai. The Court of Appeal held that the Native Land Court was the proper forum for the consideration of native title in land. Yet, critically from his overall strategic and case management perspective, he failed to obtain a declaration from the ordinary courts to the effect that the beds of non-tidal inland navigable waters were beyond the jurisdiction of the Native Land Court. He did not manage to convey the fine subtlety of that position in his oral submissions, faltering on a bald argument as to the ability of the Crown to assert conclusively that the relevant land was Crown land not subject to customary title. On this basis, any such argument would have to occur in the Native Land Court should the litigation continue. After all, section 90 of the Native Land Act 1909 read that, "The Native Land Court shall have exclusive jurisdiction to investigate the title to customary land, and to determine the relative interests of the owners thereof." This was the practical significance of Salmond's loss. The Crown legal approach was confronted with the prospect of not readily containable litigation in a specialist court on "native land".

The special case stated proceeding was removed form the Supreme Court into the Court of Appeal by an order of Justice Edwards dated 10 July 1912. Salmond's predecessor as SolicitorGeneral, Frederick Fitchett, suggested resorting to one of the proceedings as a "test case" in January 1910 in the wake of having been served on 22 December 1909 with the identical writs of summons and statements of claim in both Tamihana Korokai (as it was initially framed) ${ }^{51}$ and Tieri te Tikao $v$ Attorney-General (regarding Lake Rotoiti). ${ }^{52}$ In the subsequent month, Salmond considered that the appropriate course would be to proceed by a special case stated process in one of the actions, whilst

49 See Salmond to Ngata (22 December 1909) AAMK 869, box 84b, 5/13/242, pt 4, Arawa Lakes 1904-1925, Archives New Zealand, Wellington.

50 Frame Southern Jurist, above n 1, 115.

51 The full intituling in the documents on the Crown Law Office litigation file (Case 84) described the parties as follows: "Tamahana [sic] Korokai of Rotorua, New Zealand Aboriginal Native on behalf of himself and other Natives who are the owners according to Native custom and otherwise of the land covered by the water known as 'Lake Rotorua' (plaintiffs) and The Honourable the Attorney-General (defendant)". But for the change in the identity of the defendant party, the description of the parties was identical in the Court of Appeal.

52 Fitchett, Solicitor-General, to Joseph Augustus Tole, Crown Solicitor, Auckland (11 January 1910) Crown Law Office Case 84A, Wellington. 
deferring the other. ${ }^{53}$ In that correspondence with the Crown Solicitor in Auckland, Salmond proposed a number of possible issues of law, such as whether the "Native title extends to the bed of lakes such as Rotorua and Rotoiti" and whether the "grant of freehold titles to the adjoining land carries with it a grant of the bed or any part thereof". ${ }^{54}$ In addition, Salmond recommended a specific question addressing rights of fishing: "whether the Native owners of the adjoining land have any exclusive rights of fishing or other user". ${ }^{55}$ Joseph Tole, the Crown Solicitor, reported on 8 March 1910 that Frederick Earl of the legal firm Earl and Kent in Auckland, the solicitor for the two plaintiffs, Tamihana Korokai and Tieri Te Tikao respectively, had consented to the proposal of stating a special case for consideration in the Court of Appeal. ${ }^{56}$ On account of the office of Attorney-General falling vacant at or near the critical time of the anticipated fixture in the courts, the description of the defendant party was eventually amended to read Solicitor-General by order of the Supreme Court (27 June 1912). By consent of the parties, the Tieri Te Tikao v Attorney-General case did not proceed, as its statement of claim in respect of Lake Rotoiti was essentially identical to that in Tamihana Korokai.

Certain elite members of particular Te Arawa hapū were certainly aware of the testing of the issue of the proprietorship of the two lakes in judicial proceedings. Henry Taiporutu ("Tai") Te Mapu-o-te-rangi Mitchell, of Ngāti Pikiao, for one, was cautious in adding his support to those advocating the repeal of the Thermal Springs District Act $1881^{57}$ at a meeting at Ohinemutu on 25 May 1910. He commented that while "most of the Arawa hapus favour the repeal of the [Thermal Springs] Act - [the] only reason for keeping it was the doubt whether the testing of the Lake Question would be prejudiced". ${ }^{58}$ The litigation had been in the planning for some time with the parliamentarian, Āpirana Ngata, advising Gilbert Mair in April 1909 that the "question of the ownership of the lakes is being brought to a head, for I learn that the matter has been placed in the good hands of Mr Earl and Mr Skerrett, and that the various tribes interested are getting together a

53 Salmond, Solicitor-General, to J A Tole, Crown Solicitor, Auckland (5 February 1910) Crown Law Office Case 84, Wellington.

54 Ibid.

55 Ibid.

56 J A Tole, Crown Solicitor, Auckland, to Salmond, Solicitor-General (8 March 1910) Crown Law Office Case 84 .

57 The Thermal Springs Act 1881, 45 Vict, number 20, 24 September 1881, was an "Act to provide for the settlement of the Thermal-Springs Districts of the Colony". Section 2 authorized the Governor to issue "Proclamations from time to time defining districts of the colony to be subject to this Act, being localities in which there are considerable numbers of ngawha, waiariki, or hot or mineral springs, lakes, rivers, or waters, and [to] from time to time ... vary the boundaries or abolish any of such districts".

58 Minutes of meeting, Tamatekapua, Ohinemutu (25 May 1910) AAMK, 869/84b, 5/13/242-1, Archives New Zealand, Wellington. 
fund for legal expenses". ${ }^{59}$ Subsequently in June, Mair recorded that he presided over a meeting of "delegates of Te Arawa hapu" with the purpose of raising funds "to test their rights to the lakes". ${ }^{60}$ In 1909 Ngata, a member of the Executive Council of Joseph Ward's government, was himself under some pressure from Mitchell, especially with the Native Land Bill before the House of Representatives. Mitchell, an official in the Auckland district office of the Department of Lands, considered Part IV of the Native Land Bill, which contained clauses 84 and 100, to be objectionable. In November 1909 he noted that, as the Native Land Bill would affect "Taupo Lake which is outside the Thermal Springs Act", he could not "see how we are to accept with honour Ngati Tuwharetoas [sic] contribution of $£ 100$ [to the litigation fund]". ${ }^{61}$ Writing to Ngata he said that the "feeling is abroad that as a member of [ $\mathrm{t}]$ he Executive Part IV has your approval \& any attempt to delete these clauses is futile seeing the attitude you have taken up as evidenced by the proposed new legislation". ${ }^{62}$ Mitchell said, "[p]ersonally I have very little confidence in petition [to the House of Representatives] when apparently both you \& [the Native Minister, James] Caroll [sic] in conjunction with other members of the Executive are for the Bill". ${ }^{63}$ Stating that the "Lake question" was a "vital one to the Arawa people", Mitchell said, "[y]ou have actually supported the movement of bringing the matter before the proper authorities for investigation $\&$ now this whole thing is to be squashed $a$ la back door fashion \& our rights over customy [sic] lands guaranteed by a solemn Treaty are to be con[fisc]ated without compensation." 64 These approaches hastened the seeking of undertakings from Government not to use clause 84 of the Native Land Bill once it was passed. Subsequently, the Native Minister in the Reform Party government of William Ferguson Massey, William Herries, had signalled in the House of Representatives in response to a parliamentary question from Ngata, that "any undertaking given by the previous Native Ministers on this question [the Rotorua Lake case] will be duly observed". ${ }^{65}$ There was an evident political

59 Ngata to Gilbert Mair (7 April 1909) Ms-Papers-0148-074, Alexander Turnbull Library ("ATL") Wellington.

60 Gilbert Mair, diary (4 June 1909) Gilbert Mair papers - Ms-papers-0092, folder 61, ATL, Wellington.

61 Mitchell to Ngata, telegram, 19 November 1909, AAMK 869, box 84b, 5/13/242, pt 4, Archives New Zealand, Wellington.

62 Mitchell to Ngata (22 November 1909) AAMK 869, box 84b, 5/13/242, pt 4, Archives New Zealand, Wellington. The correspondence was written on the letterhead paper of the Department of Lands and Survey. In the House of Representatives in 1914, Ngata quoted from the correspondence of Te Heuheu Tukino of Tūwhareota, which said: "When the Arawas set up their claims to ownership of Lake Rotorua I asked my people to contribute to the expenses of the case, which proceeded under the Treaty of Waitangi". (3 November 1914) 173 NZPD 783.

63 Ibid.

64 Ibid.

65 The parliamentary question and answer appears in the Department of Native Affairs file as a typescript document, "Extract from Parliamentary Debates, vol 158, page 845 of 1912", MA1 W2459, box 49, 5/13/242, pt 4 (1911-1925), Lake Rotorua, Archives New Zealand, Wellington. 
context to the litigation. The executive branch - a complex aspect of government in itself voluntarily constrained its range of legal options as a matter of policy.

On hearing the submissions from 23 July 1912 until 25 July 1912, the appellate court held in its reserved judgment of 7 October 1912 that the Native Land Court could "only be prevented from performing its statutory duty, first, under the Native Land Act; or, second, on proof in that court that the lands are Crown lands freed of the customary title of the Natives; or, third, that there is a Crown title to the bed of the lake". ${ }^{66}$ In writing this passage, Stout had not explained how "Crown title" might emerge. Yet, the third option indicated that such a title might exist ab initio from the assertion of the Crown's sovereignty and in contradistinction to those lands of the Crown obtained legally and beneficially through the extinguishment of pre-existing "customary land". Thus, the second and third options suggested two distinctive routes or possibilities for the existence of a Crown title. The second option implied some form of extinguishment, for instance, of pre-existing customary land status before an unqualified Crown title could materialise. The third option could be interpreted as connoting pre-existing Crown title not subject to customary title since the accession of sovereignty in 1840. On the possible range of options, the amended statement of defence initially filed on behalf of the Solicitor-General in the Tamihana Korokai proceedings before the Supreme Court was unequivocal. Paragraph 16 of that amended statement of defence stated that the "bed of Lake Rotorua is Crown Land which is and always has been free from Native Customary title". The alternative possibility of extinguishment or abandonment of the customary title, if any, having occurred was also pleaded in the amended statement of defence. ${ }^{67}$ The latter pleading averred that, "For many years the lake has been openly and continuously used as a right by the Crown and the public as a highway subject to a public right of navigation, and as a public fishery and place of public recreation, without any claim of exclusive use or ownership being made by the Natives, and the Native customary title, if any such title ever existed, has been therefore lost by implied cession surrender or abandonment." 68 It is partly for the existence of the second and third options above that the Crown Law Office was not prepared to concede that Lake Rotorua was, as a matter of either fact or of law, Māori "customary land" within the meaning of the Native Land Act 1909. ${ }^{69}$

66 Tamihana Korokai v Solicitor-General, above n 9, 345-346 Sir Robert Stout, CJ. Chief Justice Stout would repeat this passage as the finding of the Court of Appeal when presenting the decision of the Full Court of the Supreme Court in Waipapakura v Hempton, above n 8, 1070. Sir Robert Stout's diary entries are terse on the case. For instance, the entry for Tuesday, 23 July 1912 simply reads: "In appeal Court re Rotorua Lake case" (Ms-20262-2064, ATL).

67 Paras 20-21.

68 Amended statement of defence, in the "Special Case Stated Pursuant to Rule 245", 8, Crown Law Office Case 84 .

69 In terms of the historical context, therefore, I disagree with the implications regarding the stance of the Crown presented in R Boast Foreshore and Seabed (LexisNexis, Wellington, 2005), 23: "However, the Crown Law Office, led at that time by Sir John Salmond, despite Tamihana Korokai, remained very 
A close survey of the judgment yields additional reasons for the Crown's legal stance. The answers to two of the questions posed in the case stated proceeding were read by the Chief Justice on behalf of the Court of Appeal and reproduced towards the end of the official report of the judgment. ${ }^{70}$ First, the Court held that the Native Land Court had jurisdiction "to entertain and determine a claim by Natives to be owners of land claimed by the Crown, and to determine such a claim by an order binding the Crown". ${ }^{71}$ Second, Stout confirmed that it was a first instance question for the Native Land Court to: ${ }^{72}$

[D] etermine upon proper evidence whether any particular piece of land is Native customary land or not, and in ascertaining this it may determine whether or not the area described in the application as "Lake

Rotorua", or any part of it, is or is not a navigable lake; and, if so, whether according to Native custom the Maoris were and are the owners of the bed of such lake, or whether they had and have merely a right to fish in the waters thereof.

This sort of language undoubtedly encouraged the Crown's legal advisors to regard the claims to the bed of Lake Rotorua as contestable at law and in evidence. Stray dicta in the judgments of the Court of Appeal casually intimated that the historical official view was that "for every part of land there was a Native owner." Even that, however, was subject to subtle qualifications in the Tamihana Korokai judgment, such as references to "habitable" land, as opposed to areas that could not be inhabited. ${ }^{73}$ Earlier asides from Court of Appeal judges had indicated changing judicial views on

reluctant to concede that lakebeds merely had the status of ordinary Māori customary land". The Office considered that the Court of Appeal in Tamihana Korokai had contemplated a range of possible legal conclusions under the Native Land Act 1909.

70 Refer to Tamihana Korokai v Solicitor-General, above n 9, 358-359 Sir Robert Stout, CJ.

71 Ibid, 358.

72 Ibid, 359 (emphasis added).

73 Refer to Stout's judgment in ibid, above n 9, 340 citing comments by George Augustus Selwyn, Bishop of New Zealand, in 1860 as an authority for the proposition ("that there was originally a distinct owner for every habitable spot in the Northern Island") along with observations of the former Chief Justice, William Martin in 1847: "the whole surface of the Islands, or as much of it as is of any value to man, has been appropriated by the Natives, and, with the exception of the part which they have sold, is held by them as property." The source for the quoted passages from Selwyn and Martin was the collection of "opinions of various authorities on native tenure", collated by Alexander Mackay, Native Commissioner, and presented to both Houses of the General Assembly of New Zealand in 1890: Mackay to Native Minister (17 March 1890) "Opinions of Various Authorities on Native Tenure", AJHR [1890] G-1, 3 (Bishop Selwyn, extracted from "Memorandum to the Governor, May 1860") and at 3 (Martin, cited as being from a "pamphlet of 1846" [sic], but actually lifted from his anonymously prepared pamphlet of 1847 entitled England and the New Zealanders; Part 1 - Remarks upon a Despatch from the Right Hon Earl Grey to Governor Grey dated Dec 23 1846, (Bishops' Auckland, Auckland, 1847) 47). See also Appendix A, "Opinion on Native Tenure", "Appendix to the Governor's dispatch of $4^{\text {th }}$ December 1860", in AJHR [1861] E-1. 
the Treaty of Waitangi. ${ }^{74}$ Again though, the opinions of the judges gave succour to the view that it was for the Native Land Court to determine whether the type of Māori interaction with a given space was of sufficient quality in "custom" to accord with "ownership" rather than a fishing right not tied to the underlying proprietorship of the land. In an oft-neglected passage, the Chief Justice was also clear that legal recognition was purely dependent upon the incorporation of a customary interest in land into a system of freehold tenure. Thus, Stout $\mathbf{J}$ stated in a fashion reminiscent of Salmond's view that, "[t]he position all along assumed has been that the lands are vested in the Crown, and until the Crown issues a freehold title the customary titles cannot be recognized, but that the Crown will give to all who prove that the land was theirs, a freehold title."75 His Honour considered that, historically, "numerous Ordinances and Acts of Parliament have been passed to enable the Maoris to transmute their customary title into freehold". The exception to this position, noted Stout J, would be where the Crown demonstrated that it had title to the land in question or had terminated the power of the Native Land Court to issue orders by way of a proclamation under section 85 of the Native Land Act $1909 .{ }^{76}$ Section 85 of that legislation provided that a "proclamation by the Governor that any land vested in His Majesty the King is free from the Native customary title shall in all Courts and in all proceedings be accepted as conclusive proof of the fact so proclaimed". Salmond was certainly not inimical to the concept of pre-existing "customary land" status mantling land that was not submerged or land that was inundated by non-navigable internal or inland waters. In an opinion of 22 November 1916 to the Assistant Under-Secretary of Lands on Punaruku Island in Lake Rotokakahi in the district of Rotorua Salmond observed that "[t]here is no doubt that an island in a lake is just as much subject to Native customary title as the mainland until and unless that customary title has been destroyed by purchase or otherwise". ${ }^{77}$ The legal status of the adjoining mainland was considered to be irrelevant. Thus, the "mere fact" that such parcels had been acquired by the Crown was "not in itself sufficient evidence that the Island is included in the title to the adjoining mainland". As a consequence of the outcome in Tamihana Korokai, however, the way was paved for the Native Land Court to hear the claims to the various lakes in the Rotorua district:

74 For example, Justice Richmond was recorded as saying to counsel in Cook County Council v Rawiri Hinaka (1893) 11 NZLR 778, 780-781 (CA) that "The author and draughtsman of the Treaty did not consider that it had that meaning. He considered that it was limited to the actual possession of the Natives or to their actual occupation. But the modern interpretation has been that it recognised their right to every corner of the country, where a Native had never set foot".

75 Tamihana Korokai v Solicitor-General, above n 9, 341 per Sir Robert Stout CJ (emphasis added).

76 Ibid, 358.

77 Salmond, Solicitor-General, to Assistant Under-secretary of Lands (22 November 1916) ABWN 8089 W5272 Item 130, 433-435. 


\section{A "This Court has not Taken Cognisance of the Quality of Native Rights, but the Fact of Such Rights is a Question for this Court" - Whither the Common Law and Native Title?}

The success of plaintiff was incomplete. The statement of claim initially filed on behalf of Tamihana Korokai had sought, amongst other things, a "declaration" from the Supreme Court that "the land aforesaid covered by the water known as Lake Rotorua is Native Land within the meaning of The Native Land Act 1894". It is salutary to note that the submissions of counsel for Tamihana Korokai supported this line of approach whilst the Crown was in opposition. C B Morison, junior counsel to Skerrett, submitted on 24 July 1912 that section 11 of the Declaratory Judgments Act 1908 empowered the ordinary courts to make declarations. That provision stated:

The jurisdiction hereby conferred upon the Supreme Court to give or make any declaratory judgment or order shall not be excluded by the fact that the said Court has no power to give relief in the matter to which the judgment or order relates, or that such matter would, independently of this Act, be within the exclusive jurisdiction of any other Court (emphasis added).

Thus, he continued, "This Court has not taken cognisance of the quality of native rights, but the fact of such rights is a question for this Court". ${ }^{78}$ Three cases were cited in support of this proposition namely the Court of Appeal decision in Re the Lundon and Whitaker Claims Act 1871 (Lundon), ${ }^{79}$ Wallis $v$ Solicitor-General, ${ }^{80}$ and Nireaha Tamaki $v$ Baker. ${ }^{81}$ He alleged that section 72 of the imperial New Zealand Constitution Act $1852^{82}$ "recognises the Treaty of Waitangi [because] it provides the native customary title can only be taken away by cession to the Crown". ${ }^{83}$ Section 87 of the Native Land Act was then referred to as presuming that a period of ten years "possession by [the] Crown [was sufficient] to extinguish native title [and] any less period would not". ${ }^{84}$ The plaintiff failed to obtain a declaration as to the "fact" of such rights with the Court of Appeal determining it to be a matter for investigation in the Native Land Court, the specialist court

78 Hubert Ostler, Assistant Law Officer, handwritten summary of "Skerrett and Morison's Arguments", Crown Law Office Case 84, Wellington, 7 (emphasis added).

79 In re the Lundon and Whitaker Claims Act 1871 (1872) 2 NZCA 41.

80 Wallis $v$ Solicitor-General [1903] AC $173(\mathrm{PC})$

81 Nireaha Tamaki v Baker, above n 2.

8215 \& 16 Vict, c 72 (Imp), 30 June 1852. Section 72 provided amongst other things, "subject to the Provisions herein contained, it shall be lawful for the said General Assembly to make Laws for regulating the Sale, Letting, Disposal, and Occupation of the Waste Lands of the Crown in New Zealand; and all lands wherein the Title of Natives shall be extinguished as herein-after mentioned, ... shall be deemed and taken to be Waste Lands of the Crown within the meaning of this Act ...".

83 Ostler, above n 78, 7. See also to the summary of their oral submissions in the report of Tamihana Korokai v Solicitor-General, above n 9, 331.

84 Ibid. 
on questions of the ascertainment and determination of native land established via statute. That is, Skerrett and Morison achieved that aspect of their client's claim, but not a "declaration of title" as to the "existence of customary land in Lake Rotorua" from the ordinary courts. In this respect, the decision of the Court of Appeal in Lundon in 1872 was of contextual interest, as the reported oral submissions of Skerrett and Morison clearly record the use of the case as support for the statement that the "Crown is bound both by the common law and its own engagements to a recognition of Native rights". ${ }^{85}$ In 1872 the Court of Appeal itself had indeed said that, "The Crown is bound, both by the common law of England and its own solemn engagements, to a full recognition of Native proprietary right". 86

Yet, none of the judges in Tamihana Korokai responded to this particular reference nor was it cited in any of the opinions. Salmond's recorded submissions in Tamihana Korokai reveal disagreement with the obiter dicta of the Court of Appeal in its 1872 ruling. Subsequently, in 1918, as he prepared case notes for the "Rotorua Lake" proceeding in the Native Land Court, Salmond accounted for the passing reference to the "common law of England" in Lundon in the following fashion: "obiter dicta ... What does this ["the common law of England"] know about native customary title". ${ }^{87}$ Arney CJ delivered the decision of the Court of Appeal in 1872. He clarified, in a manner consistent with Chapman $\mathrm{J}$ in the 1847 decision of Regina $v$ Symonds, that, "Whatever the extent of that right by established Native custom appears to be, the Crown is bound to respect it." 88 He continued with the important following comment: ${ }^{89}$

But the fullest measure of respect is consistent with the assertion of the technical doctrine, that all title to land by English tenure must be derived from the Crown; this of necessity importing that the fee-simple of the whole territory of New Zealand is vested and resides in the Crown, until it be parted with by grant from the Crown.

The analysis of the Chief Justice proceeded to observe that: ${ }^{90}$

The argument so much insisted upon [that the lands in question were "native lands" and not "Crown lands"] involves the absurdity of supposing that the Crown is granting what does not belong to the Crown.

85 See Tamihana Korokai v Solicitor-General, above n 9, 331.

86 In re the Lundon and Whitaker Claims Act 1871, above n 79, 49. The litigation file does not reveal anything further regarding the context for this particular quote.

87 Salmond "Lundon v Whitaker Claims [sic] 2 CA 41 (1872)", undated (1918?) CL174/2, Archives New Zealand, Wellington.

89 Ibid (emphasis added).

90 Ibid, 50. 
He explored this assertion further with the comment: "If nothing passed by grants from the Crown to Natives of lands already owned by themselves under Native custom, it would be an idle ceremony to issue such instruments." 91 Yet, he added, "something does pass - the whole legal fee passes; and in respect of this legal fee remaining vested in the Crown down to the time when the grant passes the seal of the Colony and receives the Governor's signature, every such instrument may, with absolute propriety, be termed a grant of Crown lands." 92 From the vantage point of 1912, it would have been understood that the Lundon case was specifically about the interaction between the Crown Grants Act 1866, the Native Lands Act 1865 and the leasing of native lands, rather than any alleged common law obligations of the Crown. That is, it would have been appreciated what was at issue legally for the purposes of a particular judgment. The concept of the Crown's underlying title as a fee simple differed from succeeding late twentieth and early twenty-first century views as to "radical title" although I do not explore this question in detail in this essay.

The distinct reference to the "common law of England" binding the Crown, expressed in obiter dicta, did not suggest to legal counsel or to the Court of Appeal in the early twentieth century a discrete source for the legal acknowledgement or recognition of enforceable customary rights at common law, as opposed to a Treaty-centred stance on statute-based law. ${ }^{93}$ It did not form part of

91 Ibid.

92 Ibid.

93 This obiter dicta would, however, be gathered up by commentators in the late twentieth century (McHugh was the pathfinder) and early twenty-first century to suggest a golden thread of reasoning about native title independently actionable at common law in the courts. See, most notably, J Evans "Reflections on Nireaha Tamaki v Baker" (2007) 2 Te Tai Haruru: Journal of Māori Legal Writing, 103-132; F M Brookfield Waitangi \& Indigenous Rights: Revolution, Law \& Legitimation, (rev ed, Auckland University Press, Auckland, 2006) 128-129; John William Tate "Hohepa Wi Neera: Native Title and the Privy Council Challenge" (2004) 35 VUWLR 73, 103, n 107. McHugh in 1984 ("Aboriginal Title in New Zealand Courts" (1984) 2 Canterbury LR, 235, 245-251) was of this disposition but has since altered his viewpoint in relation to New Zealand legal history, principally due to the methodological influence of J G A Pocock (for this turn in McHugh's stance, see, for instance, M Walters "Histories of Colonialism, Legality, and Aboriginality" (2007) 57 UTLJ 819, 822-823). J Evans alleges that the "common law" comment in Lundon was part of the ratio of the decision "because to reach its decision the Court had to determine whether the lands in question were 'crown lands', in the sense of the 1866 Act, notwithstanding the existence of the native title" (Evans, ibid, 103-132, 116, n 47). I disagree. The Court of Appeal was confronted with a situation where Native Land Court orders ascertaining title had been made under the Native Lands Act 1865 and certificates of title had already been issued or were about to issue in respect of the ascertained customary proprietors under the Native Lands Act 1865. All of the relevant legal events flowed from interpreting that statutory situation. The certificates of title are on the Crown's litigation file. The Court held that, had section 75 of the Native Lands Act 1865 continued to apply, "uncorrected by subsequent legislation", then the leases made after the Native Land Court orders but before the issuing of certificates would have been void at law. The Crown Grants Acts of 1866 and 1867, however, altered the decision. The Court of Appeal said that "the effect [of section 7(1) of the Crown Grants Amendment Act 1867] has been virtually to authorize sales and leases made by individual Natives at any time after an order in their favour under section 23 of 'The Native Lands Act 1865"' ((1872) 2 NZCA 41 at 51). It is also important to realise that the decision of the Commissioner, Alexander Johnston, and dated 15 April 1872 relies on the Treaty of Waitangi as the "basis of the policy and 
the instinctive mental architecture of the counsel or of the presiding judges. It is not sufficient to ascribe this silence to an alleged neglect, misunderstanding or forgetfulness in respect of the jurisprudence of the United States Supreme Court under Marshall CJ (from 1801 until 1835) on Native American title, or to the ruling of the Supreme Court in New Zealand in Regina v Symonds (1847) (Symonds). ${ }^{94}$ These sources were certainly cited before the Court of Appeal in Tamihana Korokai. The understanding of their meaning in 1912 (let alone 1847) ${ }^{95}$ does, however, differ from subsequent treatments of this case law in some of the legal historical literature of the late twentieth century and early twenty-first century. Unless this starting point is appreciated with its own historical subtleties and without the condescension of posterity, much of New Zealand's legal history will seem somewhat obscure and marginalised against the now conventional view that the true and correct common law (other views being simply construed as ill-advised or "wrong") was always waiting to be heroically uplifted and brought into the legal light once more. ${ }^{96}$

In this context, it is also salutary to recall that the legal system was still gradually developing a concept and the means of proceeding against the Crown beyond petitions of right or writs of scire facias and comparable to the processes involving ordinary litigant parties in private law situations. ${ }^{97}$

legislation" of both the Imperial Parliament and the colonial legislature (see report of Alexander Johnston at paragraph 13) as opposed to any "common law".

94 The use of which I have dealt with elsewhere in the context of British imperial policy formation in Mark Hickford "Decidedly the Most Interesting Savages on the Globe: An Approach to the Intellectual History of Māori Property Rights, 1837-1853" (2006) 27(1) History of Political Thought 122-167 ["Intellectual History of Māori Property Rights"]; and Mark Hickford Making "Territorial Rights of the Natives": Britain and New Zealand, 1830-1847 (D Phil Thesis, University of Oxford, 1999). Also note the recent adjustments in Paul McHugh's own view as noted in Making "Territorial Rights of the Natives": Britain and New Zealand, 1830-1847 14-19; P G McHugh Aboriginal Societies and the Common Law: A History of Sovereignty, Status, and Self-determination, (Oxford University Press, Oxford, 2004) 125 ["Aboriginal Societies"]; P G McHugh "The Common-law Status of Colonies and Aboriginal 'Rights': How Lawyers and Historians Treat the Past" (1998) 61 Sask L Rev 428-429; McHugh "A Tribal Encounter: the Presence and Properties of Common-law Language in the Discourse of Colonization in the Early Modern Period" Voyages and Beaches: Pacific Encounters 1769-1840 (Hawaii University Press, Honolulu, 1999) 114-131, 127-128. Also, Walters, above n 93, 823: "Indeed, in [Aboriginal Societies] McHugh challenges some key assumptions about Aboriginal legal history that his earlier legal scholarship helped to make respectable (perhaps even orthodox) for a generation of judges and lawyers - including the very idea that a general common law doctrine of Aboriginal rights existed historically."

95 Hickford "Intellectual History of Māori Property Rights, ibid, 145-155.

96 I believe that the historical method in this article on Salmond's approach and that of the Crown addresses some of the outstanding queries and alleged obscurities that Emeritus Professor J Evans of the University of Auckland has raised in his valuable contribution, which Professor David Williams brought to my attention in February 2007 after having read a draft of my article: Evans, above n 93, 103-132.

97 See the Crown Suits Act 1881, the Crown Suits Act 1908 and Rodney Brazier "The Monarchy" in Bogdanor (ed), above n 33, 89-45, 87. Compare W S Holdsworth "The History of Remedies Against the Crown" [1922] 38 LQR, 280-256 (I owe the Holdsworth reference to Dr Paul McHugh). In this vein, the procedural and legal situation was somewhat more complex than implied in John William Tate's otherwise detailed 
This point ought not to be lost sight of, as it informed the framework for those legal counsel operating on contested questions involving Crown grants of land. Hence, in the 1840s the public seal of the colony affixed to a Crown grant was thought to constitute conclusive evidence of the Crown's prior proprietorship, its entitlement to grant to others and the validity of the transfer. The lawfulness of a Crown grant under the public seal was assumed and could not be challenged or vitiated unless, for instance, the grantee had deceived the Crown or there was some misdescription on the face of the record that could be construed as resulting in "uncertainty". The proper process to address a Crown grant that was either void ${ }^{98}$ or voidable was to seek cancellation via the prerogative writ of scire facias, a process accompanied by its own rather complicated and specialised case law. In 1848 Chapman J had noted that the Crown's conveyance of property to third parties could only occur with grants under the public seal. ${ }^{99}$ In Regina $v$ Taylor and Regina $v$ Clarke Martin CJ had pronounced on legal principles applicable to the scire facias procedure. ${ }^{100}$ Subsequently, in 1872, a Court of Appeal bench containing three of the judges that presided in Lundon (including Arney CJ), would apply the law regarding scire facias in Regina v Fitzherbert to refuse the repeal of a Crown grant in circumstances where it was alleged that the grant "was made in prejudice of the rights of certain aboriginal natives, the former owners of lands in the grant

account of Wi Parata and Tamaki $v$ Baker in "The Privy Council and Native Title: A Requiem for Wi Parata?" (2004) 12 Waikato LR, 101; and "Tamihana Korokai", above n 39, 108. Also consider $R v$ Puketapu Sawmilling Co Ltd (1907) 29 NZLR 654 and Mudgway v Davy and Buick (1886) NZLR 4 CA 192.

98 But see $R v$ M'Intosh (No 1) vol 1 (1851) Legge 680

99 See Scott $v$ Grace (13 May 1848) reprinted in Hickford "Settling Some Very Important Principles of Colonial Law: Three 'Forgotten' Cases of the 1840s" (2004) 35 VUWLR 1-71, 71: "... it has already been decided by this Court after much consideration, in the case of the Queen v Symonds, that the Crown can convey nothing to the subject, except under the public seal of the colony" ["Three 'Forgotten' Cases"].

100 See, for example, "Report of the proceedings of a trial in the Supreme Court at Auckland, on a writ of scire facias - The Queen v George Clarke" in Colonial Office ("CO") 209/63, fos 146 and following (1-20), National Archives, Kew, London: "...where the King is not deceived in his consideration nor otherwise to his prejudice by any suggestions on the part of the grantee, but the intent was to pass the interest expressed in the Grant, only the King has been mistaken in the law; there he shall not be said to be deceived, to the avoidance of the Grant ..." (ibid, 15). The Judicial Committeee of the Privy Council upheld an appeal against the Supreme Court ruling in Clarke on another basis: $R v$ Clarke (1849-1851) 7 Moo PC 77, 84; 13 ER 808, 811 Rt Hon T Pemberton Leigh: "this is not a grant professing or intended to be made, as a matter of bounty or grace from the Crown, but it is only intended as a confirmation of that report, which was made under the authority of the ordinance". For Taylor see Hickford "Three 'Forgotten' Cases", 43 (Martin CJ) and 45 (Chapman J). Subsequently, the Judicial Committeee of the Privy Council would advise in $R v$ Hughes (1865) LR 1 PC 1 (on appeal from the Supreme Court of South Australia) that a Crown grant was not a matter of record (even when issued under the public seal) unless it had been enrolled in a court of record. The importance of this point is that writs of scire facias seeking the cancellation of a Crown grant could only secure a cancellation where the grant was a matter of record. The Judicial Committeee suggested, however (without determining the matter conclusively), that this principle might not apply in New Zealand (ibid, 92-93). 
described, and their descendants". ${ }^{101}$ Ultimately, a political resolution of the case was legislated (Native Reserves Act 1873). The Māori claimants raised two allegations in the pleadings for a writ of scire facias. First, they claimed that the Crown, at the date of the grant of 1851, held the lands comprised in that grant subject to a trust for the benefit of the aboriginal native owners. Second, it was alleged that the Crown by that instrument assumed to dispose of lands which had never been ceded to the Crown, and over which the native title had never been extinguished. In relation to the allegation that the lands in question had "never been ceded to the Crown, and that the Native title thereto has never been extinguished", Arney CJ stated that that plea could be "shortly disposed of". ${ }^{102}$ His Honour noted that: ${ }^{103}$

No formal act of cession to the Crown was necessary. From and after the purchase of these lands by the

[New Zealand Land] Company from the Natives, they became, by virtue of the alienation itself, part of the demesne lands of the Crown; insomuch that even if the purchase by the Company had been investigated by Commissioners under the Land Claims Ordinance No 1, and the same had been approved, and the Commissioners had recommended grants or a grant to the Company accordingly, it would have remained at the discretion of the Crown to make or refuse such grant. This title the Crown has always asserted. ...

It is also important to remember that the decision of Regina $v$ Symonds in 1847, which expressly admitted the relevance of the jurisprudence on common law and ius gentium (the law of nations) of the United States Supreme Court during John Marshall's period of chief justiceship and now received as a New Zealand common law source, had not yet been printed in an official law report series. Its accessibility as a printed text in 1912 was still relatively limited ${ }^{104}$ (although it was possible to obtain copies from the Great Britain Parliamentary Papers, which certain major

101 See Regina v Fitzherbert (1872) 2 NZCA 143 (CA) 165.

102 Ibid, 172.

103 Ibid, 172-173.

104 The decision of the Supreme Court of New Zealand in $R v$ Symonds (1847) NZPCC 387 was originally printed officially in The New Zealand Gazette in 1847 and forwarded to the Colonial Office in London - see CO209/53, fos 45-47a, National Archives, Kew, London. The version of Regina $v$ Symonds cited in Wi Parata $v$ Bishop of Wellington, above n 23, 72, Nireaha Tamaki v Baker, above n 2 and Tamihana Korokai $v$ Solicitor-General, above n 9, 321 was that printed in the Great Britain Parliamentary Papers 1847-1848, vol. xliii, [892], 64-71, enclosed with George Grey to Earl Grey (5 July 1847) 64. It was not reported until the publication, in 1938, of the so-called "New Zealand Privy Council Cases" or "NZPCC" volume, a collection of cases that was, according to its publishers, intended to address a request of "[m]any members of the legal profession in New Zealand for the reports of appeals from the New Zealand courts to the Judicial Committee to be contained in an accessible format" (see "Introduction" New Zealand Privy Council Cases, 1840-1932, (Wellington, 1938) ix). Also, "The inclusion of one Supreme Court judgment, delivered in 1847, The Queen $v$ Symonds ... is justified by its importance in New Zealand constitutional law, by the reference made to it in several judgments in the Reports and in the present volume, and by its previous difficulty of location." 
libraries held). ${ }^{105}$ As I have discussed elsewhere, the jurisprudence underlying Symonds was, in itself, very much contested in terms of its relevance to British imperial policy on the "territorial rights of the natives". 106 One of the presiding judges in Symonds, William Martin himself, in surveying the state of the legal treatment of native title within New Zealand, said sixteen years later in 1863 that "The case stands thus: no native can in any way enforce any right of ownership or occupation of land, held by the native tenure, in the courts of the Colony". ${ }^{107}$ The engagement of Lord Davey with Symonds is revealing for the almost casual emphasis on the relevance of statute law as distinct from a justiciable common law source. Chapman $\mathrm{J}$ was noted to have held that native title could not be "extinguished otherwise then in strict compliance with the provisions of the statutes". 108 This particular reception of Symonds persevered. In Tamihana Korokai, the Chief Justice stated that the decision in Wi Parata only "emphasized the decision in Reg[ina] $v$ Symonds that the Supreme Court could take no cognisance of treaty rights not embodied in a statute, and that Native customary title was a kind of tenure that the Court could not deal with". ${ }^{109}$ Stout J considered the advice of the Privy Council in Nireaha Tamaki v Baker as "having recognized, however, that the Natives had rights under our statute law to their customary lands". ${ }^{110}$ This was not a dramatic volte face on the part of the Chief Justice but consistent with the tenor and detail of Lord Davey's speech.

The decision of the Supreme Court in Symonds was directly placed before the Court of Appeal in Tamihana Korokai, as it was included as "Appendix C" in the documentary collection for the special case stated removed to the Court of Appeal within the Crown Law Office proceedings file. Salmond's handwritten marginalia on that reprinted version of Symonds remain of interest in relation to Chapman J's opinion that:

105 Certainly, the Grey Collection in the Free Public Library in Auckland had an extensive set of these papers according to its catalogue for 1888. The Hocken Library in Dunedin also appears to have had a set (referred to in its 1912 catalogue)

106 See Hickford "Intellectual History of Māori Property Rights", above n 94, 122-167; Hickford Making "Territorial Rights of the Natives", above n 94, as recently noted in McHugh Aboriginal Societies, above n 94, 125; Bain Attwood "The Law of the Land or the Law of the Land? History, Law and Narrative in a Settler Society" (2004) 2 History Compass 1-30, and Michael Belgrave Historical Frictions: Māori Claims $\&$ Reinvented Histories (Auckland University Press, Auckland, 2005) 29. Also, in the introductory essay, see Hickford "Three 'Forgotten' Cases", above n 99, 1-71.

107 Martin "Observations on the Proposal to take Native Lands under an Act of the Assembly", enclosed with Martin to William Fox, 16 November 1863, CO209/178, fo 163 (35), National Archives, Kew, London.

108 Nireaha Tamaki v Baker, above n 2, 579.

109 Tamihana Korokai v Solicitor-General, above n 9, 344 (CA) Stout CJ (emphasis added).

110 Ibid. 
[I]t is now part of the law of the land, and although the Courts of the United States in suits between their own subjects will not allow a grant to be impeached under [the] pretext that the native title has not been extinguished, yet they would certainly not hesitate to do so in a suit by one of the native Indians.

Salmond had underlined the section of that passage commencing with the words "not hesitate to do so...", beside which appeared the following handwritten comment in the margin: "Questioned in Wi Parata v Bishop of Wellington". ${ }^{11}$ As at 1912, Salmond was correct to point this out. In presenting Wi Parata Prendergast CJ doubted the analysis of Chapman J and referred to the passage of the text (lecture 51 in James Kent's Commentaries on American Law), which Chapman had cited in support of his proposition that the courts in the United States would "not hesitate" to entertain a suit on the part of Native Americans to impeach a grant on the ground of the native title having not been extinguished. Prendergast CJ concluded that Chapman J's statement was not a "legitimate inference" to draw from Kent's text. ${ }^{112}$ The passage in question that Prendergast CJ quoted from Commentaries on American Law stated that: 113

Even with respect to the Indian reservation lands, of which they still retain the occupancy, the validity of a patent has not hitherto been permitted to be drawn in question in a suit between citizens of the State, under the pretext that the Indian right and title, as original lords of the soil, had not been extinguished.

Likewise, the decision of the Supreme Court of the United States, Cherokee Nation v State of Georgia, ${ }^{114}$ which Chapman $\mathrm{J}$ had also relied upon, had not sustained the bald proposition that

111 Tamihana Korokai v Solicitor-General "Special case stated pursuant to Rule 245" Appendix C, 21, Crown Law Office Case 84A, Wellington.

112 Wi Parata $v$ Bishop of Wellington (1877) 3 NZ Jur (NS) SC 72, 80 Prendergast CJ.

113 Cited as "3 Kent's Com, 378" in ibid, 80. Given the passage quoted and the page reference that Prendergast provided, it could appear that His Honour was citing from the 1873 edition (James Kent Commentaries on American Law (Oliver Wendell Holmes (ed), 12 ed, vol 3, Little Brown and Company, Boston, 1873) 378), or from the 1844 edition (James Kent Commentaries on American Law (5 ed, vol 3, New York, 1844) 378). Due to the relative stability in the pagination from one edition to the next, it is not evident which particular edition of Kent's Commentaries on American Law the Chief Justice used.

114 Cherokee Nation v State of Georgia 5 Peters 1 (1831) (USSC). 
Chapman J had crafted. ${ }^{115}$ The Cherokee Nation case essentially determined that "an Indian tribe or nation within the United States" could not "maintain an action in the courts of the United States". 116

In response to the submissions of counsel in Tamihana Korokai, Edwards $\mathrm{J}$ said that the Supreme Court had "no jurisdiction to inquire into purely Native titles", nor could it "investigate questions arising out of the procedure and practice of the Native Land Court so long as that Court" acted within jurisdiction. ${ }^{117}$ In spite of that, he confirmed that the Supreme Court had jurisdiction: ${ }^{118}$

$[T] \mathrm{o}$ interpret the statutes to which the Native Land Court owes its existence and its jurisdiction; to confine that Court within the limits of that jurisdiction if it is being exceeded; and to compel that Court to exercise its jurisdiction if, for some fancied reason not arising out of Native customs and usages, it refuses or fails to do so.

Chapman J admitted that: "it is quite true that the Courts administering the ordinary laws have never had the means of conveniently investigating such [Native] titles". ${ }^{119}$ It was for that reason, His Honour suggested, that a "special tribunal" in the form of the Native Land Court was required. Nevertheless, Chapman acknowledged that various pieces of legislation, such as the Native Land Act 1873, recognised the existence of Maori claims to land. "The various statutory recognitions of the Treaty of Waitangi; mean no more, but they certainly mean no less, than those recognitions of Native rights". ${ }^{120}$ Perhaps addressing the obiter dicta of Arney CJ in Lundon, Stout CJ in Tamihana Korokai in 1912 did say that it was "not necessary to point out that if the Crown in New Zealand had not conserved the Native rights and carried out the treaty a gross wrong would have been

115 For brief synopses of the opinion of the Supreme Court of the United States in Cherokee Nation v State of Georgia, see Lindsay G Robertson Conquest by Law: How the Discovery of America Dispossessed Indigenous Peoples of their Lands (Oxford University Press, New York, 2005) 131-132; Howard Berman "The Concept of Aboriginal Rights in the Early Legal History of the United States" (1978) 27 Buff L Rev 637, 656-660; Burke "The Cherokee Cases: A Study in Law, Politics, and Morality" (1969) 21 Stan L Rev 500, 503-516; Lisa Ford "Settler Sovereignty: Jurisdiction and Indigenous People in Georgia and New South Wales, 1788-1836" (PhD Thesis, Columbia University, 2007) 385-387.

116 Cherokee Nation v State of Georgia, above n 114, 20 Marshall CJ. Importantly, the language of Marshall CJ was guarded and non-committal regarding the possibility of entertaining suits concerning land: "That part of the bill which respects the land occupied by the Indians and prays the aid of the court to protect their possession, may be more doubtful. The mere question of right might perhaps be decided by this court in a proper case with proper parties. But the court is asked to do more than decide on the title. The bill requires us to control the Legislature of Georgia, and to restrain the exertion of its physical force. It savors too much of the exercise of political power to be within the proper province of the judicial department. " (Ibid).

117 Tamihana Korokai v Solicitor-General, above n 9, 349.

118 Ibid.

119 Ibid, 358.

120 Ibid. 
perpetrated", ${ }^{121}$ although the obligation was certainly perceived to be political in nature rather than one sourced and legally enforceable in common law.

Nor is it proper to simply attribute the different understanding to a predilection towards a socalled Austinian or "positivistic" conception of law, as certain commentators have been inclined to do. ${ }^{122}$ In New Zealand at this time, the Treaty of Waitangi and not the common law was viewed as the source of political or "moral" claims to legal rights on the part of Māori. Skerrett was manoeuvered to say that, "[o]ur rights are statutory, [and] therefore can only be interfered with under statutory powers". ${ }^{123}$ The thread of Skerrett's presentation was expressed in a sequence of steps founded upon the Treaty entered into in 1840. First, he stated that: "Before settlement Maoris were permanent occupiers of all land in [the] North Island and whether occupied in fact or not [they were] treated as occupiers." ${ }^{124}$ Skerrett admitted that, "If rights [had] not been founded on treaty [then the] question might have arisen but [the] treaty [and] legislation recognised [the] right to occupancy of all land in [the] North Island". ${ }^{125} \mathrm{He}$ argued that, hitherto, the prevailing stance of the ordinary courts within New Zealand concerning the Treaty of Waitangi had been "erroneous" because "no Court has [the] right to question [the] status of natives as a state fixed by the treaty". ${ }^{126}$ At this juncture, the decision of Gillies $\mathrm{J}$ in Mangakahia \& Anor v New Zealand Timber Co Ltd in 1882 was cited in Skerrett's submission as evidence of judicial criticism of the Wi Parata approach on the status of the Treaty of Waitangi at law. ${ }^{127}$ In that case, Gillies J had posed the legal question:

121 Ibid, 343.

122 See, for example, Frederika Hackshaw, "Nineteenth Century Notions of Aboriginal Title and Their Influence on the Interpretation of the Treaty of Waitangi" in I H Kawharu (ed) Waitangi: Māori and Pākehā Perspectives of the Treaty of Waitangi (Oxford University Press, Auckland, 1989) 92-120, 92-93, 99-103 and Paul McHugh in 1991: The Mãori Magna Carta: New Zealand Law and the Treaty of Waitangi (Oxford University Press, Auckland, 1991) 116 [The Mãori Magna Carta]. Evidently, the intellectual genealogy of any policy or legal decision ought to be approached with methodological care. See the caution in Stefan Collini Public Moralists: Political Thought and Intellectual Life in Britain 1850-1930 (Oxford University Press, Oxford, 1991) 2-5 (method), 256-268 (reception of Austinian analysis in legal scholarship and teaching). See also, Stefan Collini, Donald Winch and John Burrow "The Governing Science: Things Political and the Intellectual Historian" in That Noble Science of Politics: A Study in Nineteenth-century Intellectual History (Cambridge University Press, Cambridge, 1983) 3-21.

123 Ostler "Skerrett and Morison's Arguments", above n 78, 10.

124 Ibid, 2.

125 Ibid.

126 Ibid, 2-3 (Skerrett referred to Wi Parata $v$ Bishop of Wellington, above n 112 as an exemplar of the approach: "Prevailing view of Courts in [New Zealand] erroneous. Have always treated Treaty of Waitangi as a nullity [and] relied on previous discovery and settlement".

127 Mangakahia \& Anor v New Zealand Timber Co Ltd (1884) 2 NZLR 345 (SC) 350: "Theoretically the fee of all lands in the colony is in the Crown, subject nevertheless to the "full, exclusive and undisturbed possession of their lands," guaranteed to the natives by the Treaty of Waitangi which is no such "simple 
"[w]hat title does legally recognised ownership [under the Native Lands Act 1873] according to native custom confer?" and responded with the comment: "I answer that no title known to English law is thereby conferred." 128 Once ascertained by the Native Land Court, Gillies J accepted that $\mathrm{a}:{ }^{129}$

$[\mathrm{P}]$ re-existing right according to native custom is thereby recognised and declared - an exclusive right of occupation - a right to sell or otherwise dispose of that right of occupation - a right to inherit not according to the rules of English law but according to Maori custom - all these are recognised and declared, but though in many respects they are analogous to, they are not equivalent to, a title in fee simple.

The Supreme Court explained that, "If a recognised and declared native owner sell to a European the purchaser does not derive his title from the vendor, he merely extinguishes the vendor's right of occupation, but derives his title from the Crown". ${ }^{130}$ It was not treated as a legal estate upon which one could found an action in trespass. ${ }^{131}$

In accordance with his line of reasoning regarding the Crown's political acceptance of the status of the Treaty of Waitangi, Skerrett insisted that, "If the Crown treats the Maoris as an independent state that is binding on this Court", as the "[s]tatus of natives is determined by the Crown [and the] Court is bound by that determination". ${ }^{132}$ Skerrett concluded that the "rights of Treaty where Natives have become subjects are cognisable by [the] Courts". ${ }^{133}$ Yet he confessed that this "point [was] only of academic interest, because [the] treaty recognised [was] recognised by our Statute law and thus given [the] effect of law". ${ }^{134}$ In addition, he submitted that "the Native land legislation is

nullity," as it is termed in Wi Parata $v$ The Bishop of Wellington, quoted in argument in this case" [footnote omitted].

128 Ibid.

129 Ibid.

130 Ibid.

131 Unless the party taking trespass action was in the possession of the land subject to a "memorial of ownership" under the Native Lands Act 1873. Justice Gillies held that, "The argument used, that according to this doctrine the native would have no remedy against trespass on his lands, is fallacious. So long as he is in possession he has his remedy. If out of possession he must perfect his occupationary title by exchanging it for a title under the Crown, where he can claim all the rights and remedies incident to such a title" (ibid, $351)$.

132 Ostler "Skerrett and Morison's Arguments", above n 78, 2.

133 Ibid, 3. In the official report's summary of his submissions it was also noted that: "The rights of Natives rest upon the treaty and not upon their bare rights jure gentium: see article 2 of the treaty": Tamihana Korokai $v$ Solicitor-General, above n 9, 329.

134 Ibid. 
only explained by reference to [the] Treaty". ${ }^{135}$ Salmond was certainly at pains to distinguish the relevant United States judicial sources on the grounds that "American Natives are looked upon as separate political communities", and "by the American Constitution a treaty is part of the supreme law of the land, to be taken notice of and enforced by the law-courts, and prevailing over a statute". ${ }^{136}$ In contrast to the United States, he used a number of cases to illustrate the English and imperial position, including Cook $v$ Sprigg. ${ }^{137}$ In that case, the Privy Council dealt with a claim that grantees of mineral and other concessions from a paramount chief of Pondoland prior to the acquisition of British sovereignty via cession were enforceable against the incoming Crown. In dismissing the claim of the grantees, the Lords advised that: ${ }^{138}$

All that can be properly meant by [the] proposition [that private property is respected by the sovereign accepting a cession] is that according to well-understood rules of international law a change of sovereignty by cession ought not to affect private property, but no municipal tribunal has authority to enforce such an obligation.

\section{B Detailing the Crown Legal Theory Further - Territorial and Non-territorial Customary Rights in 1914}

In 1914 Salmond secured a favoured Treaty of Waitangi-based or centred account of Māori customary fishing rights at law in the judgment of the Full Court of the Supreme Court in Waipapakura $v$ Hempton (Waipapakura). A common law source for customary proprietary rights did not feature in the relevant conception of the Crown's legal stance at all. It was not merely a statute-based argument but a Treaty-centred theory also. ${ }^{139}$ If this is properly appreciated, then the analytical subtleties of the developing Crown "register", which Salmond and his colleagues were exploring in internal legal advisory work, become considerably clearer (not to mention the areas of convergence and divergence with the varied perspectives of legal commentators as at, say, 2007). Section 8 of the Fish Protection Act 1877 had referred to fisheries rights arising out of the Treaty of Waitangi of $1840 .{ }^{140}$ It stated that: "[n]othing in this Act contained shall be deemed to repeal, alter, or affect any of the provisions of the Treaty of Waitangi, or to take away, annul, or abridge any of

135 Ibid.

136 Ibid, 333.

137 Cook v Sprigg [1899] AC 572 (PC).

138 Ibid, 578.

139 Compare McHugh The Maori Magna Carta, above n 122, 118-119 and 121-122; John William Tate "Tamihana Korokai and Native Title", above n 39, 108.

140 Fish Protection Act 41 Vict, number 45 (8 December 1877) "An Act for the Protection of Fish and Fisheries in New Zealand". 
the rights of the aboriginal natives to any fishery secured to them thereunder". ${ }^{141}$ In argument before the court in Waipapakura v Hempton, Salmond averred that section 8 of the Fish Protection Act 1877 corresponded with section 77(2) of the Fisheries Act 1908, which provided that, "Nothing in this Part of this Act shall affect any existing Maori fishing-rights". That is, he submitted that it was "merely a saving clause and [did] not create rights". ${ }^{142}$ The case emerged out of the seizure on 22 August 1913 of a set of fishing nets from one Waipapakura by fisheries officers on the grounds of an alleged breach of clause 3 of regulations made under the Fisheries Act 1908 dated 19 September $1911 .{ }^{143}$ The nets in question had been used for fishing in the tidal waters of the Waitara River on the mid-western coast of the North Island in Taranaki. Waipapakura had been using more than one set-net in conjunction with groynes in order to capture whitebait. The case was initially heard before Alfred Crooke, the stipendiary magistrate at Waitara. The plaintiff, Waipapakura, claimed $£ 10$ in damages from the defendant, John Hempton, the Collector of Customs at New Plymouth, on the basis that his agents "acting under his orders and directions, converted to his own use and wrongfully deprived the plaintiff of the use and possession" of three whitebaitfishing nets. ${ }^{144}$

The reserved decision of the stipendiary magistrate, presented in the case on appeal document for the Supreme Court, recorded that the plaintiff had been using a groyne, involving a series of heaped stones running from the bank of the Waitara River to its centre line, with sets of nets fixed between the stones. ${ }^{145}$ In delivering his reserved judgment on 26 November 1913, Alfred Crooke nonsuited the plaintiff's claim for damages upon the ground that the existence or otherwise of Māori fishing rights could only be ascertained and proved via the Native Land Court process, but he gave leave to Waipapakura to appeal his decision. The magistrate referred to a particular finding of the Court of Appeal in Tamihana Korokai as authority for the proposition that the Native Land Court had "jurisdiction to inquire into a claim by the Maoris of a customary right of fishing". ${ }^{146}$ Indeed,

141 By way of comparison, section 11 of the Wanganui River Trust Act 1891 stated that, "Nothing in this Act contained shall affect any rights conferred upon the Natives by the Treaty of Waitangi, or shall be deemed to confer upon the Trust any jurisdiction over private lands, or over any Native lands the title to which has not been investigated by the Native Land Court ...".

142 Waipapakura $v$ Hempton, above n 8, 1068.

143 See The New Zealand Gazette (vol 2, 21 September 1911) 2816.

144 "Case on appeal from the decision of Alfred Crooke, Esq, Stipendiary Magistrate at Waitara", Supreme Court of New Zealand (Taranaki District), paragraph 1, Crown Law Office Case 267, Wellington 5.

145 Ibid, 2. The relevant passage continued with the following observation: "As the water rises with the inflow of the tide the nets are shifted from the openings in deep water to those which are nearer to the bank, and consequently in shallow water. The nets are of the same description as those which were used by the Maoris in the olden days, except that wire gauze is now substituted for rushes for the belly of the net".

146 Ibid, 4-5. 
Crooke referred to Stout CJ's statement of the conclusion of the Court of Appeal in Tamihana Korokai $^{147}$ to the effect that:

[I]t was a question for the Native Land Court to determine whether according to Native custom the Maoris (the plaintiffs in that case) were and are the owners of the bed of Lake Rotorua, and whether they had and have merely a right to fish in the waters thereof.

If he was incorrect on that point, he noted that by section 25 of the Native Land Act 1909 the Governor had power by Order-in-Council to confer jurisdiction upon the Native Land Court "in any matter or question affecting the rights of Natives in any real or personal property". ${ }^{148}$

On the appeal, Stout CJ noted in presenting the judgment of Full Court on 30 July 1914 that there was, "no allegation in this case that the land over which the tide flows belongs to the Maoris". ${ }^{149}$ His Honour remarked that "the Maoris have land adjoining, but if so the Crown grant would be to high-water mark and would not include the land under the sea or tidal waters". ${ }^{150}$ This view was undoubtedly bolstered by section 35 of the Crown Grants Act 1908, ${ }^{151}$ even though that statute was not expressly referred to either in the record of oral submissions or in the judgment itself. Legal recognition would be limited to the landward side of the high-water mark margin of the foreshore. ${ }^{152}$

So far as sea-fisheries are concerned - and the question of fishing-rights on inland rivers adjoining Maori land is not before the Court - there must, in our opinion, be some legislative provision made before the Court can recognize the private rights, if any, of Maoris to fish in the sea or in tidal waters.

In that sense, the reference to "existing Maori fishing-rights" was interpreted as connoting rights that could only yield legal consequences to the extent that they were accorded distinct statutory recognition elsewhere. Stout CJ did not share what such a discrete form of provision might have looked like in the context of fisheries within the tidal waters of New Zealand.

Yet the key explanation for Stout CJ's position on "legislative provision" in the judgment is not to be found in the text of his decision. That official report is merely a remnant - tanquam tabula

147 See Tamihana Korokai v Solicitor-General, above n 9, 359 (CA).

148 "Case on appeal from the decision of Alfred Crooke, Esq, Stipendiary Magistrate at Waitara", above n 144, 5.

149 Waipapakura v Hempton, above n 8, 1072.

150 Ibid.

151 Section 35 of the Crown Grants Act 1908 provided: "Where in any grant the ocean, sea, or any sound, bay, or creek, or any part thereof affected by the ebb or flow of the tide, is described as forming the whole or part of the boundary of the land granted, such boundary or part thereof shall be deemed and taken to be the line of high-water mark at ordinary tides."

152 Waipapakura $v$ Hempton, above n 8, 1072. 
naufragii (like a plank from a shipwreck). Rather, the relevant context is to be located in Salmond's legal submissions in the Crown Law Office litigation file, as those submissions were merely summarised in the official report of Waipapakura $v$ Hempton, with much of the explanatory subtlety concealed. Salmond proposed that the two principal questions posed for the Supreme Court were, first whether Maori fishing rights could be recognised by any court other than the Native Land Court and, second whether any such rights existed and, if so, what were those rights. The status of the Treaty of Waitangi in New Zealand law and constitutional history formed the centrepiece of Salmond's argument. "This treaty", said Salmond, "has not itself the force of law and is not in itself the source of legal rights". ${ }^{153} \mathrm{He}$ added that, "It so operates only if and so far as the rights so referred to have been transformed by statute into legal rights. Tamihana case." ${ }^{154}$ The line of reasoning then turned to the native land legislation: "So far as customary ownership [of land] is concerned this has long since been done". Earlier in the typescript document, Salmond considered that, "[t]erritorial fisheries of the Maoris are of two kinds: (1) On Native freehold lands (2) On Native customary lands". ${ }^{155}$ He stated that nothing in the Fisheries Act 1908 was intended to affect those rights. Thus, "Maoris have undoubtedly fishing rights in all Native freehold lands", whilst it could not be doubted that territorial fisheries rights existed in respect of "customary land", as "they [were] incidental to and included in the right of Native customary ownership recognised by [the] Native Land Act". ${ }^{156}$

Such rights were, therefore, "legal statutory rights" although Salmond added that it may be "sufficient for the present case to point out that the locus in quo is not claimed or proved to be Native customary land: what is claimed is apparently a non-territorial fishery". ${ }^{157}$ Hutchen, for the appellant, disavowed any claim to the bed of the tidal waters of the Waitara River. ${ }^{158}$ So-called "non-territorial" fisheries were the "customary rights of Maoris to fish in waters which do not belong to them", although it was evident, Salmond argued, that "no such rights [subsisted] in land for which Native title [had been] extinguished". ${ }^{159}$ Non-territorial rights could only exist over Crown lands, which had "never been the subject of Native ownership at all". ${ }^{160}$ There were only two classes of land that could be supposed to be in that position according to the argument of the Solicitor-General, specifically tidal waters and inland navigable waters. Tidal waters were the locus

153 Salmond "Waipapakura v Hempton", argument, Crown Law Office Case 267, Wellington, 7.

154 Ibid.

155 Ibid, 2.

156 Ibid.

157 Ibid, 2-3.

158 See Waipapakura v Hempton, above n 8, 1066.

159 Salmond "Waipapakura v Hempton", argument, above n 153, 6.

160 Ibid. 
in quo in the Waipapakura litigation. The "boundary of Maori customary rights of ownership" was the high-water mark: "All land below high-water mark vested in the Crown by prerogative free from [the] Native title". ${ }^{161}$ Salmond perceived this legal point to be significant, as a contrary answer would imply that enclosed waters, such as harbours and bays, the foreshore and tidal waters would "belong to the Maoris except, [in] so far as the Crown [could] establish by purchase or otherwise that Native rights have been extinguished". ${ }^{162}$

There were three entwined points that sustained the particular stance of the Crown. First, at common law the land inundated by tidal waters was within the proprietorship of the Crown. In support of this statement, Salmond used the third edition of the established English common law text by H Coulson of the Inner Temple and Urquhart Forbes of Lincoln's Inn, released in 1910. ${ }^{163}$ Second, the presumed seaward limit of Crown grants to its subjects (including Māori), and "[t]herefore of that statutory grant constituted by the Treaty of Waitangi" was the high-water mark (a line of same imprecision in itself). ${ }^{164}$ It was, said Salmond, "Absurd to suppose that the whole country is fringed with a strip of land still belonging to Maoris by custom, because [it had] not [been] included in other Crown grants". ${ }^{165}$ Third, the public rights of fishing and navigation in tidal waters were rights that it had "not since Magna Carta [been] within the prerogative of the Crown to take away" (although this position was not as well-grounded as the extant case law suggested). ${ }^{166}$ This implied limitation upon the prerogative power residing with the Crown was submitted to have legal consequences for the practical reach of the Treaty of Waitangi. As such, "[t]he Treaty and subsequent statutes should not be so construed as to take away this right by conferring on the Maoris

161 Ibid.

162 Ibid, 6-7.

163 Salmond was relying upon H Coulson and Urquhart Forbes The Law Relating to Waters, Sea, Tidal and Inland (3 ed, Henry Sweet, London, 1910) 23, 26. This particular edition is no longer held within the Crown Law Office library.

164 Salmond "Waipapakura v Hempton", argument, above n 153, 7.

165 Ibid.

166 Ibid. The reference to Magna Carta had become almost de rigueur in the context of exclusive fisheries at this time. However, Hubert S Moore, in his 1910 chapter on "Fisheries" in Halsbury's Laws of England, had cautioned that the interpretation of Magna Carta as preventing the exercise of the Crown's prerogative power to derogate from the public right of fishing through granting exclusive fisheries could be doubted on historical grounds: "There is considerable weight of evidence to show that Magna Charta had no bearing on the right of the Crown to create several fisheries; see Moore, History and Law of Fisheries, ch 2": Hubert S Moore, "Fisheries" The Laws of England, Being a Complete Statement of the Whole Law of England, by Right Honourable the Earl of Halsbury, Lord High Chancellor of Great Britain (1885-86, 1886-92, and 1895-1905) \& other lawyers, (Vol 14, Butterworth \& Co, London, 1910) para 1270, note t. See also, Geoffrey Marston The Marginal Seabed: United Kingdom Legal Practice (Oxford University Press, Oxford, 1981) 61-68. 
exclusive rights of ownership, possession or use". ${ }^{167}$ The principal citation for the first part of this proposition was the barrister Hubert Stuart Moore's contribution of the chapter concerning "fisheries" in the fourteenth volume of Halsbury's Laws of England published in 1910. ${ }^{168}$ In the margin, Salmond had written in his own hand a reference to the recent advice in December 1913 of the Privy Council in Attorney-General of British Columbia v Attorney-General for Canada. ${ }^{169}$ A certain construction of the sixteenth chapter of the Magna Carta of Henry III vis-à-vis the exclusivity of a several fishery (together with its relevance to the dominion of New Zealand within the British Empire) underlay the Crown submission in Waipapakura. That chapter stated that, "No rivers shall be defended from henceforth, but such as were in defence in the time of king Henry our grandfather, by the same places, and the same bounds as they were wont to be in his time." ${ }^{170}$ The Lord Chancellor, Viscount Haldane recognised in Attorney-General of British Columbia $v$ AttorneyGeneral for Canada that the "legal character" of the right of subjects of the Crown to navigate and fish the "high seas and tidal waters alike" was difficult to define. ${ }^{171}$ In seeking a rationale, Haldane surmised that: ${ }^{172}$

Finding its subjects exercising this right as from immemorial antiquity the Crown as parens patriæ no doubt regarded itself bound to protect the subject in exercising it, and the origin and extent of the right as legally cognizable are probably attributable to that protection, a protection which gradually came to be recognized as establishing a legal right enforceable in the Courts.

The Privy Council was aware that, historically, there were exceptions to the maintenance of the jus or ius publicum with regard to fishing, specifically the existence of exclusive rights of fishery.

167 Salmond "Waipapakura v Hempton", argument, above n 153, 7

168 Salmond was referring to Hubert S Moore "Fisheries", above n 166.

169 Attorney-General of British Columbia v Attorney-General for Canada [1914] AC 153 at, to use Salmond's handwritten references in the margin, "p 168, p 1701/2, 1711/3". The decision of the Judicial Committeee was dated 2 December 1913 and Salmond evidently had a copy of the official reported "Appeal Cases" version of the case in advance of the argument of Waipapakura $v$ Hempton on 9 July 1914.

170 Magna Carta, 9 Hen III, c 13-17, 1224-1225, "Nulla riparia de cetero defendatur [Nulle riparie defendantur de cetero] nisi ille que suerunt in defenso tempore Regis Henrici avi nostri per eadem loca et [per] eosdem terminus sicut esse consueverunt tempore suo." It is noted that only (1297) 25 Edw I (Magna Carta) c 29 applies in New Zealand under the Imperial Laws Application Act 1988. Chapter 29 states: "No freeman shall be taken or imprisoned, or be disseised of his freehold, or liberties, or free customs, or be outlawed, or exiled, or any other wise destroyed; nor will we not pass upon him, nor [condemn him] but by lawful judgment of his peers, or by the law of the land. We will sell to no man, we will not deny or defer to any man either justice or right." Compare M Walters "Aboriginal Rights, Magna Carta and Exclusive Rights to Fisheries in the Waters of Upper Canada" (1998) 23 Queen's LJ 301; David Clark "The Icon of Liberty: The Status and Role of Magna Carta in Australian and New Zealand Law" (2000) 24 MULR 34.

171 Attorney-General of British Columbia v Attorney-General for Canada, above n 169, 169.

172 Ibid. 
Haldane noted that the sixteenth chapter of the Magna Carta of Henry III was of a general nature and was clearly not restricted to tidal waters.

Importantly, the Lord Chancellor stated that: ${ }^{173}$

If [the words] had remained unconstrued by the Courts doubt might well have been entertained, as pointed out by Lord Blackburn in Neill $v$ Duke of Devonshire, whether the $16^{\text {th }}$ chapter, ..., did more than restrain the writ de defensiore ripariæ, by which, when the King was about to come into a county, all persons might be forbidden from approaching the banks of the river, whether tidal or not, in order that the King might have his pleasure in fowling and fishing.

But then, in a passage that revealed the instrinsically ahistorical nature of common law reasoning, Haldane advised that since the 1862 decision of the House of Lords in Malcolmson $v$ O'Dea: ${ }^{174}$

[I]t has been unquestioned law that since Magna Charta no new exclusive fishery could be created by Royal grant in tidal waters, and that no public right of fishing in such waters, then existing can be taken away without competent legislation. ${ }^{175}$

Salmond would have observed the statement of the privy council that, "This is now part of the law of England, and their Lordships entertain no doubt that it is part of the law of British Columbia". The reception of English common law on the question of Magna Carta, the possibility of exclusive fisheries existing in tidal waters and for the received English common law to exercise a constraint on the interpretive possibilities of the Treaty of Waitangi and statutes such as the Fisheries Act 1908. Salmond did not pause to consider what, if any, relevance the comments of Chief Justice Stout in Baldick v Jackson in 1910 on the reception of English common law and statute on the right of the monarch to whales by virtue of the royal prerogative might have had on his argument. ${ }^{176}$

173 Ibid, 170. In Neill v Duke of Devonshire (1882) 8 App Cas 135, Lord Blackburn had, in citing Matthew Hale's De Jure Maris, queried the interpretation of Magna Carta, but nevertheless accepted that the House of Lords had settled the matter in 1862: Malcolmson v O'Dea (1862) 10 HLC 591, 618 Hayes J.

174 Malcolmson $v O^{\prime} \mathrm{Dea}$, ibid.

175 Attorney-General of British Columbia v Attorney-General for Canada, above n 169, 170. See also Coulson and Forbes The Law Relating to Waters, Sea, Tidal and Inland (Henry Sweet, London, 1880) 37: "Prior to Magna Charta the Crown had power to exclude the public from this right and to grant, a several and exclusive right, of fishing to individual subjects. This right cannot be granted by the Crown, and a several fishery in the sea can now only be claimed by prescription, or ancient usage presupposing a grant, or by express grant from the Crown prior to Magna Charta."

176 Baldick v Jackson (1910) 30 NZLR 343, 344-345: "I am of opinion that this statute has no applicability to New Zealand, and that though the right to whales is expressly claimed in the statute of $17 \mathrm{Ed}$ II, c.2, as part of the Royal prerogative, it is one not only that has never been claimed, but one that it would have been impossible to claim without claiming it against the Māoris, for they were accustomed to engage in whaling; 
As tidal waters were vested in the Crown, the question for Salmond was whether the Supreme Court could take away such notice of customary non-territorial rights of fishing. In response he commented that, "Even if such rights exist by custom, they had never been given statutory recognition or legal validity". ${ }^{177}$ It was also his view that, "In the present case... the locus in quo is not Native freehold land; if it was, the question would arise whether the provisions of the Act can be said to affect such rights". ${ }^{178}$ The Fisheries Act 1908 was "designed to protect those [proprietary] rights, [and] not to take them away"; examples included "close[d] season[s] and restrictions on the methods of fishing". ${ }^{179} \mathrm{He}$ stated that, "it is in the interests of the Maoris themselves that these restrictions should be imposed". ${ }^{180}$ The submissions stressed that the rights referred to in section 77(2) of the Fisheries Act 1908 were "the private and propriet[a]ry rights of the Maoris not their liberty to fish [possessed in common with the public] the tidal waters". ${ }^{181}$ Accordingly, the submissions averred that, "[s]o far... as the fisheries mentioned in [Article II of] the Treaty are territorial fisheries [linked to Māori ownership of land], they have become and still remain legal rights". ${ }^{182}$

Contrary to this position, however, Salmond submitted in a subsequent part of his argument "that non-territorial fisheries have never received any statutory establishment or recognition". ${ }^{183}$ Regarding "non-territorial fisheries", Salmond claimed that it was, "[b]y no means clear that the word "fisheries" in the Treaty", meant anything other than "territorial fisheries, but whether this is so or not, statutory legal recognition [was] so limited". ${ }^{184}$ A marginal comment in the SolicitorGeneral's handwriting recorded the view that there was "no reference to fisheries in the original treaty", presumably adverting to the Māori language text of the Treaty of Waitangi, which was silent on the specific question of fisheries. For Salmond, it was evident that non-territorial fishing rights were not recognised in the Native Land Act 1909 - the "[o]nly customary rights recognised by this Act are rights of ownership" and only the Native Land Court had the "power to transmute customary

and the Treaty of Waitangi assumed that their fishing was not to be interfered with ...". Paul McHugh made this observation in 1984 in "The Legal Status of Māori Fishing Rights in Tidal Waters" (1984) 14 VUWLR $247-273,256$

177 Salmond "Waipapakura v Hempton", argument, above n 153, 7.

178 Ibid (emphasis in original).

179 Ibid.

180 Ibid.

181 Ibid, 1.

182 Ibid, 7-8.

183 Ibid, 8.

184 Ibid. 
ownership into freehold". ${ }^{185}$ Indeed, he observed that a, "freehold order cannot be made in respect of incorporeal hereditaments". ${ }^{186}$ The typescript submission proceeded to conclude that, "[s]ince therefore non-territorial fishing rights [were] not recognised by [the] Native Land Act they [were] not brought by that Act within the exclusive jurisdiction of [the] Native Land Act". ${ }^{187}$ Were such rights to exist at all, in Salmond's view, then they could be taken notice of in other Courts. Given that observation, however, the "transformation of customary fishing rights into legal rights must be found in some other statute", although Salmond claimed that there were "no such statutes". ${ }^{188}$ "If there [were] any such statutes," Salmond argued, "they must be special Acts dealing with particular lands". The submissions then noted that it was "impossible to say" that there were no pieces of legislation but that it was "for the appellant [Waipapakura] to prove their existence". 189 The Horowhenua Lake Act 1905 was mentioned as an illustration of an Act of Parliament that recognised "territorial fisheries only". ${ }^{190}$ It was in this fashion that the true sense of Salmond's submission that section 77(2) of the Fisheries Act 1908 was merely a savings clause is conveyed. As with section 8 of the Fish Protection Act 1877, it could not, on the argument presented by Salmond, "transform into legal rights the rights referred to in the Treaty". ${ }^{191}$ From the perspective of the Solicitor-General the "recognition by statute of non-territorial rights would have necessitated an elaborate body of minute legislative provisions similar to the Native land legislation dealing with territorial rights". ${ }^{192}$ Nevertheless, "there [was] not a word of such legislation to be found in the statute book". 193

\section{LITIGATION IN THE NATIVE LAND COURT AND PROBLEMS OF LAW AND EVIDENCE - RIGHTS OF "EXCLUSIVE POSSESSION" AND RIGHTS LESS THAN OWNERSHIP}

Salmond's perspective on the Treaty of Waitangi and native title could not contain litigation in the Native Land Court or insulate government from the consequences of that litigation. It could, nevertheless, provide a basis for contesting claims that were considered unattractive from a political

185 Ibid.

186 Ibid.

187 Ibid.

188 Ibid.

189 Ibid.

190 Ibid. Section 2(a) of the Horowhenua Lake Act stated that, "The Native owners shall at all times have the free and unrestricted use of the lake and their fishing rights over the lake, but so as not to interfere with the full and free use of the lake for aquatic sports and pleasures."

191 Ibid, 9

192 Ibid.

193 Ibid. 
perspective. In a constitutional setting that was predominantly political (not juridical), legislative assistance could, on occasion, be enlisted to sustain or to interpose a particular form of, or preference for, executive control over potentially contentious subjects. The aspiration that Salmond had expressed for the Tamihana Korokai appeal was that an ordinary court would resolve the overarching legal status of navigable inland waters. As will be seen, the foiling of that aspiration brought the role of the Native Land Court and political negotiation to the fore.

The political context surrounding the proceedings in Tamihana Korokai continued to operate following the decision of the Court of Appeal. Between 1912 and the general election in December 1914, Massey's government enjoyed a slight majority in the House of Representatives. A contest for electoral seats and political advantage was evidently at play with Ngata sensitive to any Reform Party charges that he was in government when the Native Land Act 1909 was enacted and seeking out points of political distinction. In a pre-election circular of 1914, Āpirana Ngata interpreted the Tamihana Korokai judgment in the following fashion: "Those Courts [sic] gave their decisions against the Government and the rights of the Maori people to these lakes were conserved", adding that the "Arawa people thus secured this right to the Maori people and this aspect of the Treaty of Waitangi was thus made clear." 194 The piece went on to cajole Massey's administration for designing a "confiscatory measure" in the form of clauses in the proposed Native Land Amendment Bill of 1914 that would have permitted the Governor to proclaim any rivers or lakes "in respect of which the Native rights have not been extinguished", as reserved for "general public purposes ... whether [the rivers or lakes were] navigable or not". A court of compensation would be constituted with all of the powers and jurisdiction of the Native Appellate Court. In any claim of deprivation of customary rights, the claimant could "apply to the Native Land Court to have all such rights defined and the persons entitled to compensation therefore ascertained". Herries was aware that certain Te Arawa had queried at a meeting at Tametekapua in Ohinemutu on 13 January 1913 whether parts of the Rotorua lakes might be sold or leased to the Crown. A "large Native deputation" asked the Minister's "opinion in regard to the money collected by the Tourist Department as revenue from the Rotorua lakes in view of the Court of Appeal decision recently given". ${ }^{195}$ Rogers of Te Arawa reportedly said that the "Natives interested desired [that] some scheme re this matter should be evolved, and that the question was being asked whether these lakes should be leased or sold to the Government". ${ }^{196}$ Ngata's circular, however, said that, "this Government did not trust the sense of

194 "Summary of Hon AT Ngata's pre-election circular attached" 1, AAMK 869 Box 84b, 5/13/242, pt 4, Archives New Zealand, Wellington.

195 Herries, Native Minister, to Under-secretary of Native Department, 7 February 1913, MA31, Box 26, Archives New Zealand, Wellington. Rogers handed the Minister a memorandum "Matters to be brought before Hon Native Minister". The first item was headed "The Lakes" and said "Lease or sell to Government".

196 Ibid. Herries reported that, "In replying, I said that so far as the Lake question was concerned I would fight the Natives in the Native Land Court when the question of the ownership of the Lakes is before that 
justice of the Arawa people; it was afraid that the Natives, when possessed of these lands, would deal harshly with the Dominion and European tourists". Ngata claimed that: ${ }^{197}$

[I]f it were during the term of office of the Government of Timi Kara and Ward, Timi Kara would have stood in the courtyards of the Arawa or the other peoples who own lakes and appealed to their sense of generosity as chiefs.

Herries withdrew the proposed clauses but with statements pointing to his underlying public policy concern: the preservation of public space. In the critical debate with Ngata in the House of Representatives on 3 November 1914, Herries disagreed that the clauses were confiscatory. ${ }^{198}$

I think the honourable member for the Eastern Maori District, and all the Natives, will admit that it would never do for some of the Natives to sell to a syndicate the rights of fishing or the right of navigation in Lake Rotorua or Lake Taupo.

In letting the clauses go, the Minister's view was that the "public must purchase the rights of the Natives and that is what this clause was intended for". 199

Addressing Tamihana Korokai in a note to the Under-Secretary of Lands dated 11 June 1917, Salmond observed that, "an attempt was made to get the Supreme Court to determine the legal position of the navigable inland waters of this country in relation to Native owners". ${ }^{200}$ "Unfortunately", he added, "it was not found possible to obtain any definite decision from that Court [sic] in the matter". ${ }^{201}$ As noted, the term "customary land" was defined in section 2 of the Native Land Act 1909 as, "land which, being vested in the Crown, is held by Natives or the descendants of Natives under the customs and usages of the Maori people". Salmond supposed that the Court of Appeal had held that the Native Land Court "had to determine in each particular case whether the land covered with water was Native customary land in respect of which a freehold order could be

tribunal, but it would be an honourable fight and in the open, not a treacherous one, and that there would not be any stabbing from behind in the dark. The Native Land Court had yet to decide the ownership of these lakes. The decision of the Court of Appeal was to the effect that the Natives had the right to go to the Native Land Court and to decide the ownership. That Court may say that the bed only belonged to the Natives and not the water; or that the Natives owned up to a certain distance from the shore of the lake and no farther. That question had yet to be decided by the Court before the Natives could lease or sell."

197 "Summary of Hon AT Ngata's pre-election circular attached" 2, above n 194.

198 (3 November 1914) 171 NZPD 786.

199 Ibid. "However, things can be managed in another way, and I am quite prepared to drop these clauses, as I admit they may cause some alarm to the Natives, though I think that alarm is unfounded [ibid]."

200 Salmond to Under-secretary of Lands, 11 June 1917, CL174/2, 1 Archives New Zealand, Wellington.

201 Ibid. Salmond's note to the Under-secretary of Lands was erroneous in suggesting that the Supreme Court, as opposed to the Court of Appeal in Tamihana Korokai v Solicitor-General, above n 9, effectively determined the case stated proceeding. 
obtained or whether on the other hand the Natives possessed merely customary fishing rights, in respect of which no order could be made, as opposed to rights of native ownership which were capable of being transformed into freehold". ${ }^{202}$ Section 92 of the Native Land Act 1909 stipulated that on the investigation of title to customary land and the determination of the relative interests of the owners, "the [Native Land] Court shall make an order (in this Act called a freehold order) defining the area so dealt with, naming the persons found entitled thereto, and specifying their relative interests in the land". His rendition of the meaning of the Court of Appeal's ruling in the special case stated proceeding on appeal in Tamihana Korokai was revealing. It demonstrated an assumption that the Native Land Court ought to embark upon a fine evidential assessment as to whether Māori applicants for an investigation would have had non-territorial customary rights (such as certain fishing rights not tied to the underlying proprietorship of the submerged land $)^{203}$ or "rights of native ownership" deserving a finding of "customary land" (subsequently transmuted into freehold status via an order of the court). ${ }^{204}$ On this premise there was a possibility that Māori would not satisfy the probative threshold on the evidence for a finding of "customary land status" in the Native Land Court. This would be viewed as a necessary implication of the concept of "customary land" even though the statutory language was conspicuously silent. In addition, it did not necessarily coincide with the ramifications of the ruling in Waipapakura in 1914 where it was argued that the jurisdiction of the Native Land Court extended to the investigation of title to land and not to the investigation of fishing rights.

An application for the investigation of whether the bed of Lake Rotorua might be customary land was lodged in the Native Land Court in early 1913. As Frame has observed, Salmond was not especially optimistic about the possibility of success for the preferred Crown perspective in the wake of Tamihana Korokai. ${ }^{205}$ His concern, however, predated the filing in the Native Land Court in 1913 of any application for the investigation and ascertainment of title in Lake Rotorua. His awareness of the possibilities of failure was apparent in the immediate aftermath of the decision in the Court of Appeal. On 4 November 1912, less than one month following the release of the judgment of the Court of Appeal in Tamihana Korokai, Salmond clearly thought it essential to act in order to forestall the possibility of freehold orders being effected in respect of "lakes or rivers" pursuant to section 92 of the Native Land Act $1909 .{ }^{206}$ Section 100 of that statute allowed the

202 Ibid.

203 For fishing rights tied to land proprietorship see Attorney-General v Emerson [1891] AC 649 (HL).

204 Salmond to Under-secretary of Lands, 11 June 1917, CL174/2, 1 Archives New Zealand, Wellington.

205 Frame Salmond: Southern Jurist, above n 7, 119-120. The major secondary source to date narrativising the overall historical question of lakes and Māori interests in such inland waters in New Zealand is White, above $n 5$.

206 Salmond to Attorney-General, 4 November 1912, MA1 W2459, box 49, 5/13/242, pt 4 (1911-1925), Lake Rotorua, Archives New Zealand, Wellington. 
Crown by Order-in-Council to "prohibit the Native Land Court or the Appellate Court from proceeding to ascertain the title to that [customary] land or to make a freehold order in respect thereof". He advised that an Order-in-Council be obtained under section 100 of the Native Land Act 1909 "prohibiting the Native Land Court from investigating the title and making freehold orders." 207 This was legal advice for the Attorney-General carefully adapted to the perceived risk profile for the Crown.

Salmond cautioned, nevertheless, that any move to deploy the provisions of section 100 should only occur upon the determining by the Native Land Court of the "preliminary question whether such waters are by Māori custom the subject of exclusive proprietary right at all or whether on the other hand they are merely the subject of rights of fishing and navigation". 208 This reflected the findings of the Court of Appeal in Tamihana Korokai, as Stout CJ had held that an investigation of relevant Māori "custom" ought reveal whether the applicants, and the interests they purported to represent, "were and are the owners of the bed of such lake, or [alternatively] had and have merely a right to fish in the waters thereof". ${ }^{209}$ Salmond was encouraged in particular by the dicta of Edwards $\mathrm{J}$ in Tamihana Korokai. Justice Edwards had considered that one potential contention for the Crown would be that there was "no absolute right of ownership in extensive bodies of inland navigable waters but merely rights of fishery which would not serve as a basis for a freehold order." 210 The Judge accepted that "it is quite possible - indeed, not improbable - that there never was any Maori custom or usage which recognised any greater right in land covered by navigable non-tidal waters than [a right to fish]". ${ }^{211}$ Each claim would have to be tested on its merits however. "Therefore, as Salmond correctly observed, in the Rotorua case the Court of Appeal refused to express any opinion leaving it to be decided on the facts by the Native Land Court". ${ }^{212}$ In expressing this view, it is not evident that the Crown Law Office cited or was even aware of the Kauwaeranga decision in 1870 of a former chief judge of the Native Land Court, Fenton. ${ }^{213}$

At this stage, then, there was clearly an assumption that the Native Land Court might draw the distinctions that Salmond wished to convey in legal opinion work when dealing with applications

207 Ibid.

208 Ibid.

209 Tamihana Korokai v Solicitor-General, above n 9, 359.

210 Salmond to Under-secretary of Lands, 11 June 1917 5, CL174/2, Archives New Zealand, Wellington.

211 Tamihana Korokai v Solicitor-General, above n 9, 351 Justice Edwards.

212 Salmond to Under-secretary of Lands, 11 June 1917, 5, CL174/2, Archives New Zealand, Wellington.

213 Kauwaeranga (1870) 4 Hauraki MB 236, reprinted and annotated by Alex Frame (1984) 14 VUWLR 227; Parumoana (1883) 1 Wellington MB. RP Boast, "In re the Ninety Mile Beach Revisited: The Native Land Court and the Foreshore in New Zealand Legal History" (1993) 23 VUWLR 145; F Sinclair "Kauwaeranga in Context" (1999) 29 VUWLR 139. 
for the investigation of title in land. Indeed, he considered that Tamihana Korokai had fortified his position. In writing to the Crown Solicitor in the Lake Rotorua litigation before the Native Land Court on 24 October 1918, Salmond said that it was "not disputed by the Crown that the Natives have and always have had rights of fishing and navigation in Rotorua and other inland lakes and waters". ${ }^{214}$ He added that: ${ }^{215}$

What is contended by the Crown is that these rights are rights of user only and not rights of exclusive ownership such as exist in respect of dry land and that therefore they cannot be made the foundation of a freehold order.

Elsewhere, Salmond stated that, "No freehold order can be made in respect of mere rights of fishery, navigation, or other incorporeal rights." 216 Salmond's written submissions prepared for the Native Land Court hearing in the Rotorua litigation were certainly sensitive to possible weaknesses in the Crown's case. He confessed that: ${ }^{217}$

It may be suggested, however, that the Judge [Justice Edwards] means to say that if such a custom [of ownership of navigable waters] is proved it has necessarily been given legal validity. That the legislation is in all respects as wide as the Native custom and therefore that this Court could only give effect to that native custom by making a freehold order. The Judge, however, does not say so. This would be directly contrary to the subsequent decision of the Court of Appeal [sic] in Waipapakura $v$ Hempton to which Edwards J was himself a party. There it was held that whatever the extent of Native custom may be it had not been granted legal effect with respect to tidal waters. If there was such a custom or usage the Treaty so far as it is effective is sufficient to preserve it. How far is it effective? Only so far as it has been given effect to by statute.

The historical practice of the Native Land Court was understood as primarily responsive to an assumption that "land" (a potentially contestable term in itself) ${ }^{218}$ had identifiable Māori

214 Salmond to Prendeville, Crown Solicitor, 24 October 1918, at 2, CL174/2, Archives New Zealand, Wellington.

215 Ibid.

216 Salmond "Rotorua Case" 3, CL174/2, Archives New Zealand, Wellington.

217 Ibid, 10 (emphasis added).

218 In the argument on the "Rotorua Lakes case" in 1918 this contest as to the meaning of "land" in the phrase "customary land" was apparent. Frederick Earl KC, arguing for the applicants for the investigation of Lake Rotorua and Lake Rotoiti, said, "It might be suggested that this land is not land by law, but a Lake is land covered by water. I presume we are not concerned as to whether Lakes Rotorua and Rotoiti were or were not formed by Gaseation. These Lakes are according to law merely land covered with water, they would pass under the word 'land' [in the English language version of the Treaty of Waitangi] and certainly under the words properties and estates": Crown Law Office, "Lake Rotorua Case 1918, Evidence", CLI74/1, at fo.22 (B.16), Archives New Zealand, Wellington. The legal argument of the Crown on this question was proposed as follows: "The question is therefore whether the term 'land' in the Native Land Act includes inland navigable waters of such a description as Taupo, Rotorua or Wakatipu. This must be determined by 
proprietors. The transaction costs in that jurisdiction were considered to lie principally with the identification or ascertainment of relevant proprietors rather than a first order inquiry into the overall evidential and legal quality and degree of connection to the land. That is, the identification of "who" held the relative interests in a certain area or parcel of land as opposed to whether the interests per se were of a type equivalent to a certain conception of "ownership" that would lead to freehold legal status. The Crown, however, in contesting an application, however, would generate an evidential approach that was directed as much to the weighting of the customary interest in a specific judicial forum; in essence, whether the relative relationship to a resource amounted to "rights of native ownership" or, alternatively, a class of non-territorial rights. The active engagement of the Crown altered the dynamic of the proceeding in requiring the question as to the legal status of the ongoing connection of applicants to a lake was equivalent to "ownership" to be tested through the presentation of evidence and argument.

Salmond had expressly introduced the parlance of "territorial rights" to New Zealand litigation on fisheries in the context of Waipapakura $v$ Hempton in argument on 9 July 1914. This conceptual divide, deployed in Salmond's legal submissions in that case, was premised upon a corresponding distinction that had materialized in the third edition of the English treatise by the London-based barristers, Coulson and Forbes, which addressed The Law relating to Waters, Sea, Tidal and Inland and was published in 1910. The first edition, issued in 1880, had also used the sundering between territorial rights of fishing and, implicitly, those that were not of that class. "We shall make use of the words territorial fishery to define that kind of several and exclusive fishery arising from and connected with the ownership of the soil in non-tidal waters". ${ }^{219}$ Another prominent text, resorted to in New Zealand at this time, Halsbury's Laws of England, preferred the phrase "corporeal fishery" in opposition to one that was "incorporeal", although Salmond's use of the respected work of Coulson and Forbes admitted the alternative vocabulary, based on "territoriality", to New Zealand jurisprudence. In the barrister Hubert Stuart Moore's chapter on "Fisheries" in Halsbury's Laws of England a fishery that was characterised as "corporeal" denoted one that was united with the proprietorship of the underlying land so that the right to fish would ordinarily be regarded as an inheritance with the submerged land - "the right of fishing being a profit of the soil like the grass of the land". ${ }^{220}$ This divide between a "territorial" and "non-territorial" class of rights proved to be very serviceable in the New Zealand context, albeit at a rather generic, broad analytical level. ${ }^{221}$

reference to the purpose and subject matter of the Native land legislation": Crown Law Office, "Rotorua Case", undated, 1918(?), CL174/2, 10, Archives New Zealand, Wellington.

219 Coulson and Forbes, above n 175, 337 (emphasis in original).

220 Moore "Fisheries" The Laws of England, Being a Complete Statement of the Whole Law of England by Right Honourable the Earl of Halsbury, Lord High Chancellor of Great Britain, 1885-86, 1886-92, and 1895-1905, \& other lawyers (vol 14, Butterworth \& Co, London, 1910) 572. 
That is, the particular forms of fishery and fishing right described in Coulson and Forbes' text found, in general, no corresponding echo in the legal regime regarding fisheries in New Zealand. It was, moreover, a conceptual classification that had a genealogical thread running back to the 1830 volume of the Law of Waters by Woolrych. ${ }^{222}$ According to the 1880 edition of The Law relating to Waters, Sea, Tidal and Inland, the English common law contemplated the possibility of four principal types or categories of fishery, specifically a "common fishery", a "several fishery", a "free fishery" and a "common of fishery". Much complexity attended each classification. A "several fishery" was described as a "right of fishing in a particular place exclusive of all others" and existed prima facie in the proprietor of the soil of non-tidal waters, in which case it could be called a "territorial fishery. ${ }^{223}$ The owner of a several fishery, whether owner of the soil or not, [could] maintain trespass for breaking his several fishery and taking his fish, and has a privileged property in the fish before they are caught."224 The authors commented on the ambiguous use of the term "free fishery". Confusion had arisen over its use to "express a several fishery in a public river" whereas the key distinction between a "several fishery" and a "free fishery" was said to be that the latter was a "fishery in a certain place, not exclusive, but co-extensive with the rights of others". ${ }^{225}$

221 It would consciously re-appear in McHugh "The Legal Status of Maori Fishing Rights in Tidal Waters", above n 176, 257, in 1984 (directly calling upon Salmond's use of the phraseology in Waiapapakura $v$ Hempton) and in Te Weehi v Regional Fisheries Officer in 1986 (reported in [1986] 1 NZLR 680 (HC)). By that decade, the analysis had altered considerably. Justice Williamson in the High Court said at 692 that: "I note that the customary right contended for in this case is not based upon ownership of land or upon an exclusive right to a foreshore or bank of a river. In that sense this claim is a "non territorial" one. The customary right involved has not been expressly extinguished by statute and I have not discovered or been referred to any adverse legislation or procedure which plainly and clearly extinguishes it. It is a right limited to the Ngai Tahu tribe and its authorised relatives for personal food supply. It differs significantly from the rights contended for in the Weepu and Keepa decisions. So far as the Waipapakura decision is concerned I note that there is no suggestion of any set nets or structures in the soil of the foreshore and no exclusive right is contended for in this case."

222 Refer to Woolrych The Law of Waters and of Sewers (London 1830) 87: "A right of any kind, means, in strict language, a profit or easement, which is enjoyed in the soil of another; and thus, when we speak of a right of fishery, we mean the liberty of fishing in the water of another; and it has been so defined. When, therefore, we discover that the soil over which the stream runs, and the water itself, belong to the same person, we do not say correctly that such an individual has a right of fishery, because the land and the profits are so completely identified as his inheritance, that they cannot be separated. If any description be applied to it, it should be that of territorial fishing, because the party has the dominion over the territory or land itself".

223 Coulson and Forbes, above n 175, 338.

224 Ibid (citing Holford v Bailey (1849) 13 QB 426 and Child v Greenhill (1639) Cro Car 553).

225 Ibid. 


\section{IMPLICATIONS OF THEORY FOR CROWN EVIDENTIAL METHOD AND LITIGATION MANAGEMENT}

Theory also implied certain practical consequences for methodological approaches to evidence. Section 100 of the Native Land Act 1909 was no longer available, having been repealed in $1913 .^{226}$ In 1918, against the background of applications to the Native Land Court relating to Lake Rotorua, Lake Waikaremoana and the inner harbour of Napier, Salmond and the Department of Lands and Survey attempted to obtain ministerial interest in having it reinstated. They failed. Attorney-General Francis Bell noted that Salmond's view of the utility of section 100 "assumes that the very arbitrary power conferred upon the Government by that section would be always properly used". ${ }^{227} \mathrm{He}$ said that, "Whether that assumption can be properly made is a matter not for lawyers but for Parliament". His view, "as a member of Parliament and of the Government is that it is in general not wise or safe to confer upon the Government such arbitrary powers as were exercisable under section $100 . " \mathrm{He}$ doubted whether "it was a fair power to assume", having regard to the "obligation of the New Zealand Government to the Natives arising not only from the Treaty of Waitangi but from the whole course of the assumption of sovereignty by the Crown in New Zealand". The risk of arbitrariness was real as those obligations were "not capable of accurate definition and may be construed by one public man or class of public men in a different sense from that adopted by others". On this occasion, the Treaty was deployed as a means to condition political and legal discussion within the Crown. Bell concurred, however, with Salmond's view that "sections 85, 86 and 87 of the Native Land Act, 1909, are essential provisions for the protection of title to land in New Zealand". The Attorney-General stated that: ${ }^{228}$

If after the Crown has granted land or assumed possession and granted a tenancy in land it can be alleged in any Court that the Native title has not been extinguished, it is obvious that the root to title in land in New Zealand would be not the grant of the Crown but the proof of due cession by the customary Native owners to the Crown.

The Native Minister, Herries, agreed with Bell on the question of section 100: 229

226 Frame discusses the circumstances of its repeal briefly in Frame Salmond: Southern Jurist, above n 1, $119-$ 121. Section 100 provided that: "In respect of any area of customary land the Governor may, at any time and for any reason which he thinks fit, by Order in Council prohibit the Native Land Court or the Appellate Court from proceeding to ascertain the title to that land or to make a freehold order in respect thereof; and no freehold order made in breach of any such prohibition shall be of any force or effect."

227 Bell, Attorney-General, to Herries, Native Minister (27 August 1918) AA05 W3562 22/1750, Archives New Zealand, Wellington.

228 Ibid (emphasis added).

229 Herries, Native Minister, to Minister of Lands (4 September 1918) AA05 W3562 22/1750, Archives New Zealand, Wellington. He noted that, "Both the Solicitor-General and Mr Hawthorne are very properly, from their point of view, zealous to preserve the interests of the Crown, but the Minister who prepares legislation and Cabinet and Parliament that approve of such legislation, must take a wider view, and the interests, not 
I would like to add that a careful study of the judgments delivered by the Judges who sat in the Court of Appeal in 1912, in the case of Tamahana [sic] Korokai v The Solicitor-General, commonly known as "the Lakes Case" and a due consideration of the able exposition of the rights of the Crown and of the Natives arising from the Treaty of Waitangi and subsequent legislation, and of the judgments of the Privy Council and other Courts, convinced me that the Crown would have to retire from the politically untenable position contained in section 100 .

He concluded that he was "satisfied that no Native Minister, with all the knowledge of the rights of the Natives, as shown in the judgments previously mentioned, would have been justified in advising His Excellency to put section 100 into operation". ${ }^{230}$

In the absence of a specific statutory provision, such as section 100 Crown legal strategy was left with contesting claims in the courts or in promoting particular legislative solutions to contain the consequences of litigation. First, evidence of public (non-claimant) use of land and resources would be deployed to challenge Māori narratives of, say, continuous use and connection in the Native Land Court based on "custom" and "usage". Thus, conduct or events that could be characterised as exogenous to a descent group, such as a given hapū, could, in turn, be interpreted as sufficiently adverse or intrusive to represent an absence of "exclusivity" on the part of the claimants or as something that would compromise "exclusivity" if it had been established as having existed. The Crown Law Office was, therefore, addressing the issue of the co-existence of increasingly noticeable governmental activities and of non-claimant third parties with pre-existing Māori populations in the context of the relevant native land legislation.

This sort of evidence was potentially complicated however. Although presented as potentially adverse to customary claims, it might, paradoxically, be construed as consistent with those claims if the quantity of such material was minimal or the intensity of activities it described was relatively moderate and intermittent. The litigation in the Native Land Court at Rotorua in the "Rotorua Lakes case" proved to be illustrative of this vulnerability. These proceedings were set against the background of at least seventeen distinct applications in the Native Land Court for the investigation and ascertainment of statutorily recognised customary land, if any, in sixteen named lakes in the vicinity of the settlement at Rotorua. ${ }^{231}$ A "lakes committee" was formed to manage the

only of the Crown, but also of the subject must be considered, and the subject's rights must be carefully preserved as those of the Crown, and in a democratic country the benefit of any doubt should always be given to the subject."

230 Ibid.

231 See The New Zealand Gazette 23 May 1918, at 2049 recording the notice or panui of 14 May 1918 (Registrar's Office, Rotorua) for the hearing in the Native Land Court at Rotorua of applications for the investigation of titles in "Ngakaro Lake, Ngahewa Lake, Okareka Lake, Okataina Lake, Opouri Lake, Rerewhakaitu Lake, Rotokakahi Lake, Rotomahana Lake, Rotehu Lake, Rotoma, Tahunaroa, Tarawera Lake, Tikitapu Lake, Tutaeinanga Lake". 
applications and to assist in raising funds for the conduct of the proceedings. Mōrehu Te Kirikau was chair of that committee and had written upon the lodging of the thirteen applications in April 1918 requesting Judge Wilson to "requisition the Chief Surveyor to prepare Sketch Plans certified by him as sufficient for the purposes of the Native Land Court and so that these plans will be available when the Lakes Claim is placed before the Court". ${ }^{232}$ These inland waters included lakes such as Rotoiti, Rotorua, Ōkataina, Ōkareka, Rotomahana, Opouri (Ngāpouri), Tarawera and Rotomā. The notice or panui dated 14 May 1918 signalled that a collection of fourteen applications were to be heard at the Native Land Court in Rotorua on 19 June 1918, "or as soon thereafter as the business of the Court will allow". The remaining three applications - those to Lake Rotorua and Lake Rotoiti - had been notified previously. The initial notification in The New Zealand Gazette for Rotorua-nui a Kahu had been 28 April 1917 although the Crown Law Office was aware of an earlier application that the Registrar of the Native Land Court had notified in May 1913 (but was not pursued at that time). ${ }^{233}$ The Native Land Court began to hear the applications relating to Lake Rotorua and Lake Rotoiti on 16 October 1918.

Elements within official circles expressed some anxiety regarding the applications. On 27 May 1918, the Chief Surveyor and Commissioner of Crown Lands at the Auckland district office of the Department of Lands and Survey, H M Skeet, informed the Under-Secretary of Lands in Wellington that the Chief Judge of the Native Land Court had advised that an application had been recently lodged with the Native Land Court for the investigation of the title to Lake Ōkataina. This lake was described as a "comparatively small lake situated a few miles east of Lake Rotorua and south of Lake Rotoiti, and [was] entirely surrounded by the subdivisions of the Okataina block belonging to the Ngatitirawahi Hapu of the Arawa Tribe". ${ }^{234}$ He understood that "the applicants, for whom Mr Earle [sic], $\mathrm{KC}$ is acting, want to bring this case before the Court as a 'test'". ${ }^{235}$ Yet, the report observed that the, "Crown does not appear, except in a minor degree, to have exercised any rights of ownership over this Lake and the Crown's claim, unless supported by a legal decision that all navigable waters belong to the Crown, would I am afraid be rather difficult to uphold or prove". ${ }^{236} \mathrm{He}$ continued in saying that, "In fact, of all the Lakes in this particular District, this one in particular which the Natives claim, would appear to be in the most favorable [sic] aspect and give them the best possible chance of success, and conversely, the Crown a feeble chance of refuting

232 Mōrehu Te Kirikau to Judge Wilson, Native Land Court, 22 April 1918, NLC 563, "Lakes Case", Māori Land Court. Angela Ballara has noted that funds were being collected in early 1915: Iwi: The Dynamics of Māori Tribal Organisation From c.1769 to c.1945 (Victoria University Press, Wellington 1998) 313.

233 Registrar, Native Land Court, Auckland, to Ostler, Crown Law Office (19 May 1913) Crown Law Office Case 84, Wellington.

234 Chief Surveyor, Department of Lands and Survey, Auckland, to Under-secretary of Lands, Department of Lands and Survey, Wellington (27 May 1918) 1, CL174/2, Archives New Zealand, Wellington.

235 Ibid.

236 Ibid. 
it."237 Salmond was certainly alive to the possibilities of failure and the need for compensation. In 1917 he advised that: 238

It ought to be possible, however, to make some arrangement with the [Native Land] Court by which, if the decision is against the Crown, the making of an actual freehold order should be deferred, in order to give the Government and Parliament an opportunity of considering the whole question and making provision for the compensation of the Natives in lieu of the actual issue of freehold titles to the waters in question.

The tactical frame for the anticipated litigation in the Native Land Court was much appreciated. The Chief Surveyor suggested that it was "on these grounds that the claim to this Lake is being selected by the applicants as a Test Case, instead of Lakes Rotorua and Rotoiti, and if successful, they would use it as a lever to obtain favorable [sic] decisions in other cases". ${ }^{239}$ Accordingly, he opined that it, "would suit the Crown far better to take either Lakes Rotorua or Rotoiti, or both together as "test Cases" and I therefore beg to suggest that every endeavour should be made to prevent the Okataina case being used, and if possible, from advertised in the Panui". ${ }^{240}$ This latter suggestion was redundant, as the application regarding Lake Ōkataina had already been notified in The New Zealand Gazette let alone the relevant panui of the Native Land Court. Skeet acknowledged, however, that, should the panui have already been printed, "it would be as well to bring the altered condition of affairs before the Solicitor-General's notice, so that he can instruct as to the necessary action to be taken." 241 He recommended that Salmond direct the Crown Solicitor, James Prendeville, to proceed to Auckland to avail himself of the information at the Department of Lands and Survey there. Skeet had been informed that Te Rangihiroa Buck had visited Rotorua under "instructions from the Native Department in connection with the Natives' claims to the Lakes, and that he visited all the Lakes with representatives from the different Hapus and he prepared a map shewing [sic] the claims made to different fishing grounds by the various hapus." 242 The Crown Law Office managed to persuade counsel for the applicants to proceed with the application to Lake Rotorua in the first instance. That said, at the commencement of the hearing in the Native Land Court in Rotorua on 16 October 1918, counsel for the applicants, Earl, was able to secure agreement before the court that the Lake Rotoiti application would be considered simultaneously.

237 Ibid.

238 Salmond to Under-secretary of Lands (11 June 1917) 2, CL174/2, Archives New Zealand, Wellington.

239 Chief Surveyor, Department of Lands and Survey, Auckland, to Under-secretary of Lands, Department of Lands and Survey, Wellington (27 May 1918) 1-2, CL174/2, Archives New Zealand, Wellington.

240 Ibid, 2.

241 Ibid.

242 Ibid, 2-3. 
Prendeville objected to Earl's gathering together of the Lake Rotoiti and Lake Rotorua applications on the first day of the proceeding but failed to prevent Earl's approach.

Lake Rotorua had been proclaimed a "harbour" within the meaning of the Harbours Act 1878 on 18 January $1906 .{ }^{243}$ In that year, regulations were issued for controlling water-borne traffic on Lake Rotoiti and Lake Rotorua and the management of wharves. Provision was also made for charging dues for the use of harbour works. The administering public service department was the Department of Tourist and Health Resorts. ${ }^{244}$ Navigation and the regulation of Lake Rotorua and Lake Rotoiti as harbours emerged as an evidential issue relevant to the litigation in 1918 before the Native Land Court concerning whether the two lakes would have the status of "customary land" under section 2 of the Native Land Act 1909. The Crown Law Office requested that the Department of Tourist and Health Resorts and the Department of Lands and Survey furnish evidence of Crown and nonclaimant third party use and occupation of the two lakes with a view to establishing that the applicants in the Native Land Court proceedings could not establish the requisite exclusivity or that it had been fatally compromised, if it had ever existed. W Hill, the Tourist Agent at the Government Tourist Bureau in Rotorua was a source of information in the form of a concise communiqué addressing the status of Lake Rotorua and Lake Rotoiti as proclaimed harbours. E F Hawthorne and Raleigh John Knight of the Department of Lands and Survey supplied extensive assistance in researching the official record for evidence of non-claimant third party use together with Crownsponsored or governmental interaction with the Rotorua district lakes. Knight was based in Auckland. To assist the case in the Native Land Court in 1918, Hawthorne, a clerk in the head office of the Department of Lands and Survey, would produce a succinct typescript paper entitled "Acts of Crown and public user on Lake Rotorua". It indicated the possibility of the Crown calling seven witnesses attesting to various historical and contemporaneous aspects of navigation and the construction of marine structures, such as wharves, that occupied space within Lake Rotorua itself. ${ }^{245}$ In certain instances, the witnesses would testify as to the absence of protest or objection from Māori. Thomas Fitzgerald, a foreman-carpenter in the Tourist Department office at Rotorua was one example. It was proposed that he would testify to the erection of a stone wharf in 1898 and to its wooden extension in the absence of any "objection or protest [of the] Natives, who were fully aware of [the] progress of the work." 246

243 The classification of "harbour" was extended to Lake Rotoiti by Order-in-Council on 9 July 1906: The New Zealand Gazette, 12 July 1906, 1895.

244 Refer to Hill, Tourist Agent, Department of Tourist and Health Resorts, Rotorua, to Prendeville, Crown Solicitor, Rotorua (17 October 1918) CL174/2, Archives New Zealand, Wellington.

245 Hawthorne "Acts of Crown and Public User on Lake Rotorua" (1918) CL174/2, Archives New Zealand, Wellington.

246 Ibid. 
In a letter dated 5 October 1918 to Prendeville, the Crown Solicitor acting on the "Rotorua Lakes case", Hawthorne confessed that the ${ }^{247}$

Crown [had] certainly built wharves, introduced fish ova, charged license [sic] fees for fishing, launches

$\& c$. and generally used the lake as if it were public property, but the question we shall have to answer will be: By what authority did the Crown do those things?

He expressed some dissatisfaction at the meagre volume of fresh material discovered on the Crown's use of the lakes in spite of the considerable amount of time he had expended on research. Hawthorne, an informed civil servant in the employ of the Wellington office of the Department of Lands and Survey said that "the use of the Lake by the Crown or the public is insignificant in comparison with the use of the Lake by the Natives from time immemorial, and personally I cannot see that evidence of public user is going to help us much". ${ }^{248}$ It seemed to Hawthorne that while it was "of course impossible to anticipate the actual nature of the Natives' case ... [he had] little doubt that they [would] attempt to throw the onus of proof of ownership on the Crown". ${ }^{249}$ In Hawthorne's view, "as a mere layman", the Crown would be obliged to rely mainly on two considerations. First, that "according to Native custom there is not and never has been any tribal ownership of the inland waters of [New Zealand]"; adding that he adhered to this view "notwithstanding the apparently opposite opinion expressed in the judgment in Tamihana Korokai v The Solicitor General." ${ }^{250} \mathrm{He}$ alleged that the practice of the Native Land Court in relation to the investigation of lands surrounding the lakes supported his view. Hence, Hawthorne claimed the extracts from Native Land Court minute books, which Knight had forwarded to Prendeville, indicated that, "although the natives stated that their "lands" extended to certain posts or stakes in the Lake, the Court made orders only with respect to the lands bounded by the actual water of the Lake". ${ }^{251}$ This opinion was not strictly accurate. Prendeville would be, or would have become aware by 18 October 1918 at the latest, that several blocks the subject of orders and certificates of title in the Native Land Court had included parts of lakes or entire lakes, or had been purchased by the Crown, including Lake Opouri (Ngāpouri), and Ngahewa. Lake Opouri or Ngāpouri had been proclaimed Crown land in The New Zealand Gazette on 2 November 1915 in the wake of a resolution on the part of its proprietors to sell the parcel of approximately 2,509 acres (which included the lake according to the relevant plans). ${ }^{252}$ Irrespective of that, a distinct application for

247 Hawthorne, Department of Lands and Survey, to Prendeville, Crown Solicitor, 5 October 1918, CL174/2, 12, Archives New Zealand, Wellington.

248 Ibid, 2.

249 Ibid.

250 Ibid, 3.

251 Ibid (emphasis in original).

252 The precise acreage was 2,509 acres, two roods and eleven perches. Refer to Certificate of Title (CT) 270/94 (16 November 1915) ABWN 8102, W5279/47, Archives New Zealand, Wellington, (which was in 
the investigation of title dated 20 April 1918 was filed by Mita Taupopoki and three other individuals in respect of "Opouri Lake". In his correspondence to Prendeville, however, Hawthorne chose to ignore such precedents, assuming, that is, he was indeed aware of them. He continued this with the comment that, "All talk of native 'mana' over the Lake is nonsense: 'mana' is a purely personal thing, and does not apply to either land or water". ${ }^{253}$ Hawthorne's second point was that the "only rights of native tribes or hapus [sic] over the Lake itself are rights of fishing". ${ }^{254}$ On this supposition, Hawthorne advised Prendeville to review notes he had attached from Elsdon Best. Best had translated a passage that appeared to him to look "like claiming the land under waters of [a] lake, but the idea in a Maori's mind would undoubtedly be associated with, not the submerged land, but the food supply in the waters". ${ }^{255}$ In making a history of public law, therefore, care should always be taken with the use of the term "Crown" preceded by the definite article "the". As I have noted before, there is a danger in failing to disaggregate the notion of "the Crown" and to ignore the diverse range of its inter-departmental interests and motivations. ${ }^{256}$ The participation of Hawthorne, an informed layperson, has already been noted in terms of the preparation of evidence for the "Rotorua Lakes case" in the Native Land Court and his assessment of the potential arguments.

Hawthorne's proposal was that the: 257

Crown should admit unreservedly that the Natives' right to fish [and] other foods in lakes \&c is beyond dispute, [and] should emphasise the fact that this is the only kind of claim to the Lake that has any validity.

In the margin, however, Prendeville recorded the following terse comment against Hawthorne's proposition of the lakes being the sites for fishing rights and not title: "No. See notes of Sir John [Salmond] - no fishing rights recognised by N[ative] L[and] Act". Hawthorne would also bring an earlier Crown Law Office legal opinion of the Assistant Law Officer, Hubert Ostler, dated 13 March

favour of "His Majesty the King" as the registered proprietor) and "Plan of Rotomahana Parekarangi No $3^{\mathrm{A}}$ sec: $1^{\mathrm{B}}$ block", 7062, (approved by Judge Johnson, 23 February 1904), which included Lake Opouri within the boundaries of the block.

253 Hawthorne, Department of Lands and Survey, to Prendeville, Crown Solicitor (5 October 1918) 3, CL174/2, Archives New Zealand, Wellington (emphasis in original).

254 Ibid.

255 Ibid.

256 See Mark Hickford, review of Richard Hill State Authority, Indigenous Autonomy: Crown-Māori Relations in New Zealand/Aotearoa, 1900-1950 (Victoria University Press, Wellington; 2004) in (2006) 121 English Hist Rev 639.

257 Hawthorne, Department of Lands and Survey, to Prendeville, Crown Solicitor (5 October 1918) at 3, CL174/2, Archives New Zealand, Wellington. 
1911 to the attention of Prendeville in the specific context of outlining a possible legal strategy. ${ }^{258}$ Salmond and Ostler would appear on behalf of the Crown in the Court of Appeal's hearing of Tamihana Korokai in July 1912. In referring to Ostler's legal advice of 1911, Hawthorne acknowledged that, while it may be of interest to Prendeville, it could be superseded by the Solicitor-General's views should there be any inconsistency. Still, Hawthorne used Ostler's historical advice as indicative of a number of legal issues that might arise, specifically that of usque ad medium filum aquae ("to the middle of the water"). This well-known, rebuttable presumption at common law provided that where a non-tidal river was expressed to be the boundary of a riparian parcel of adjacent land, the proprietor of the parcel was presumed to have legal title to the middle line of the abutting riverbed. Ostler would have been aware that courts in New Zealand had recently accepted the applicability of the ad medium filum aquae presumption. In April 1905, the Court of Appeal had ruled in The King $v$ Joyce that the common law presumption had become part of the law of the colony at its foundation. ${ }^{259}$ Whether, however, the presumption might extend to significant inland waters, such as large lakes, remained indeterminate. ${ }^{260}$ One agreed statement of fact between the parties on the case stated for Tamihana Korokai in 1912 was that Lake Rotorua was "an inland non-tidal lake situated in the North Island of New Zealand, about seven miles and half in length and six miles in breadth". ${ }^{261}$ It was also admitted in that special case stated that various parcels of land adjacent to the lake were "Native customary land, other portions [were] Crown Land, other portions [were] held in freehold title by Europeans, and the residue [was] Native freehold land". Hawthorne noted that, "(on the gospel according to Ostler) the rule would also apply to the island of Mokoia [in the centre of Lake Rotorua], and radiating lines w[oul]ld run from the island to the shores of the lake intersect the converging lines from the shores of the lake to its imaginary non-existent 'centre"'. ${ }^{262}$ He characterized this conundrum as, "a metaphysical puzzle, worthy of the ancient Church Fathers!"263 In 1911 Ostler had surmised that, in respect of Lake Rotorua, if, "as is probably the

258 See Ostler, Assistant Law Officer, Crown Law Office, to the Director Commerce and Tourist Department (13 March 1911) CL174/2, Archives New Zealand, Wellington.

259 The King v Joyce (1905) 25 NZLR 78 (CA) Stout CJ and Williams, Denniston, Cooper and Chapman JJ (Edwards J dissenting).

260 I do not address the vexed legal-historical issue of section 14(1) of the Coal-mines Act Amendment Act 1903.

261 See item 1 in the "special case stated" as printed in the reported version of Tamihana Korokai v SolicitorGeneral, above n 9, 321. The elegant typescript version placed on the Crown Law Office proceedings file (Case 84A), is printed as follows: "Lake Rotorua is an inland Lake situated in the North Island of New Zealand about $7 \frac{1}{2}$ miles in length and 6 miles in breadth". The term "non-tidal" is inserted in the handwriting of John Salmond between the words "inland" and "Lake".

262 Hawthorne, Department of Lands and Survey, to Prendeville, Crown Solicitor (5 October 1918) CL174/2, 6, Archives New Zealand, Wellington.

263 Ibid. 
case", the adjacent dry land had been investigated in the Native Land Court and "freehold titles issued for it to different owners", then the most that a possible owner of such different of such land could claim would possibly be a "title to the bed [of the lake] fronting the blocks he was interested to the middle line of the Lake". ${ }^{264}$ Ostler had also revealed the expectation of at least one member of the Crown Law Office that Tamihana Korokai would authoritatively settle the "question as to who are the owners of the bed". Ostler additionally set out the "difficult question of mixed law and fact of whether there was a public right of navigation on the lake ... depending upon an implied dedication of that right by the owners of the bed of the Lake". ${ }^{265} \mathrm{He}$ acknowledged that this was the "very question in the action [then] pending before the Supreme Court [in the Tamihana Korokai proceeding]". ${ }^{266}$ The particular view of Ostler on navigation was led less by the initial proclamation of Lake Rotorua as a "harbour" pursuant to the Harbours Act 1878 than by a sense that the application of the English common law position on public rights of navigation would affect the legal situation within New Zealand. That is, Ostler concluded that if there were no public rights of navigation on Lake Rotorua when the harbour regulations were promulgated, then the regulations were "ultra vires and invalid". 267 There is collateral evidence to suggest that Salmond did indeed disagree with Ostler's viewpoint on the application of ad medium filum to Lake Rotorua. Strategically, Salmond would seek to focus the Crown case on producing evidence regarding the use of Lake Rotorua and Lake Rotoiti by Māori and others for navigation and fishing. This course was pursued with a view to presenting legal submissions that would argue that navigation and fishing constituted the customary rights that the relevant hapu of Te Arawa exercised in fact and law rather than rights tantamount to customary ownership of the lake bed (and hence the space occupied by the water column, as well as the airspace above, with practical consequences, in Salmond's opinion, for public rights of navigation and fishing in general). ${ }^{268}$

In the first edition of The Law Relating to Waters, Sea, Tidal and Inland the authors said that, "There seems little doubt but that the public may acquire a right of navigation in a non-tidal lake in

264 Ostler, Assistant Law Officer, Crown Law Office, to the Director, Commerce and Tourist Department (13 March 1911) CL174/2, at 3, Archives New Zealand, Wellington.

265 Ibid, 2

266 Ibid, 3. Ostler continued with the comment that the proceeding in Tamihana Korokai had been dormant for some time: "The writ was issued over a year ago, and a statement of defence has been filed by the Crown. It lies on the plaintiffs to take steps to bring on the action, but so far they have taken no further steps. The action will probably be proceeded with, but there is likely to be considerable delay, and there is no effective method of expediting it by the Crown."

267 Ibid, 2

268 Campbell v MacDonald (1902) 22 NZLR 65 had prompted some controversy and legislative change when the Supreme Court accepted that prima facie "the fishery in non-tidal waters belongs to the person who has a property in the bed of the stream ad medium filum aquae" and that such private rights were not interfered with under the Fisheries Conservation Act 1884. 
the same way as on a non-tidal river". 269 Thus, the text noted that, "Though rivers above the flux and reflux of the tide are prima facie private rivers, yet the public may acquire a right or easement to navigate such waters by express grant, or dedication by immemorial user, which presumes a grant, or by an Act of Parliament", ${ }^{270}$ an expression reminiscent of Ostler's conception of navigation in non-tidal lakes. The library of the Crown Law Office in Wellington received a copy of this particular edition on 11 June 1907. ${ }^{271}$ There is no evidence directly indicative of Ostler's reliance on this text. ${ }^{272}$ As noted, however, Salmond would use the third edition (released in 1910) in support of his submissions in Waipapakura in July 1914. ${ }^{273}$ The second edition of 1902 would be actively deployed in conjunction with the first edition of Halsbury's Laws of England in the litigation of Lake Rotorua and Lake Rotoiti. Indeed, Earl would cite the work of Coulson and Forbes, as well as the section by the London barrister, Hubert Stuart Moore, ${ }^{274}$ on "Water and Watercourses" appearing in the twenty-eighth volume of Halsbury's Laws of England, ${ }^{275}$ in adapting the ad medium filum aquae presumption to each of Lake Rotorua and Lake Rotoiti respectively. Moore's entries concerning the proprietorship of the soil in respect of lakes and pools were less equivocal than the relevant extracts on inland waters from the contribution of Coulson and Forbes. Moore stated, for instance, that the "soil of lakes and pools, even when they are so large that they might be termed inland seas, does not of common right belong to the Crown, and the law as to the ownership of the soil is the same as that applied to inland non-tidal waters whatever the size of the water space may be". ${ }^{276}$ Also available to the legal advisors for the Crown, however, was the seminal text on water and watercourses in the United States, namely the 1877 edition of the work of Joseph Angell - A Treatise on the Law of Watercourses with an appendix, containing statutes of flowing, and forms of declarations. ${ }^{277}$ The date of accession of this volume in the Crown Law Office library was

269 Coulson and Forbes, above n 175, 101.

270 Ibid, 95-96.

271 As at the time of preparing this essay, it resides in the holdings of Victoria University of Wellington.

272 That, in itself, is not of course determinative, as the principal case law identified in a text by way of citation in support of, propositions may, in practice, be relied upon. The key point is that the historical use of sources must be approached forensically.

273 See Waipapakura v Hempton, above n 8, 1066-1067 citing "Coulson and Forbes on Waters [3 ed, 381$]$ " in support of the distinction between a "non-territorial fishery" (characterized as "rights to fish on Crown lands") and a "territorial fishery" ("rights to fish on [one's] own lands"). This copy of the Coulson and Forbes text no longer appears to exist in the current holdings of the Crown Law Office.

274 Moore would act as the editor of the fourth edition of Coulson and Forbes, The Law Relating to Waters, Sea, Tidal and Inland published in 1924.

275 For the full title see above n 166

276 Ibid, para 764 (p 399).

277 Joseph K Angell, J C Perkins (ed) A Treatise on the Law of Watercourses with an Appendix, Containing Statutes of Flowing, and Forms of Declarations (Little, Brown, and Company, Boston, 1877). 
recorded as 11 May 1880. The legal position on navigable lakes in the United States proved to be of some importance to Salmond's argument, at least by way of exploration. In his proposed submissions for the Lake Rotorua case before the Native Land Court, Salmond wrote that the 278

[Q] uestion is simply whether the water is so large and the interest of public navigation and user so great as to form a reasonable basis for the assumption that the Crown or the Legislature did not intend the word "land" to include such waters.

He added that the "distinction between navigable and non-navigable inland waters is repeatedly drawn in America and is found quite practicable". ${ }^{279}$

In addition, Native Land Court judges were also beginning to wrestle with these possibilities. In 1916 Chief Judge Jackson Palmer had cautioned Judge Jones that he foresaw "a terrible lot of stumbling blocks" before the judge's investigation of the boundary between Tuhoe and Ngāti Kahungunu interests in Lake Waikaremoana. ${ }^{280}$ Thus, the "title to all the lands surrounding the Lake having been ascertained already, will not the Lake have to be taken as a distinct block in itself and not as an appearance to any land". ${ }^{281}$ The Chief Judge queried whether this would not be "quite new and foreign to English Law - can you show a precedent anywhere where a fee simple title has been issued for lake or a river without any dry land to support the title". ${ }^{282} \mathrm{He}$ noted that if, "it were a fishing grant I could understand it but we have no power to issue a right of piscary". ${ }^{283}$ The Chief Judge was sensitive to the fact that if proprietorship to land adjacent to Lake Waikaremoana carried "the common law title to the middle of the lake then is not the Crown the owner of the Southern and Eastern half of the Lake and the Maoris owners of the rest". ${ }^{284}$ "If that were the case", said the Chief Judge, "is not the title to the Lake already ascertained and has it not therefore ceased to be papatupu [customary land] and so where is your right to again investigate it?"285 The enormity of the potential issue was evident to Palmer. "If the boundary of the land adjoining a lake or river stops dead at the bank, then there must be a lot of uninvestigated land in New Zealand consisting of rivers

278 Salmond "Rotorua Case" undated, 1918(?) 9, CL174/2, Archives New Zealand, Wellington.

279 Ibid. In his preparatory notes for Tamihana Korokai in 1912, Salmond referred to Barney v Keokuk 94 US 324, 336 (1876); Hardin v Jordan 140 US 371 (1891) and Parker v Bird 137 US 661 (1891): "Rotorua Case - Notes", 4, Crown Law Office Case 84, Wellington.

280 Chief Judge Jackson Palmer, Native Land Court, to Judge Jones, Native Land Court (3 August 1916) MA W2459 5/13/78, volume I, Archives New Zealand, Wellington.

281 Ibid.

282 Ibid.

283 Ibid. Compare the decision of Chief Judge Fenton in Kauwaeranga, above n 213.

284 Ibid.

285 Ibid. 
and lakes and will we have to commence and investigate each of these separately, and have we not been wrong all along in the Land Court in not making such investigations before". ${ }^{286}$ Palmer revealed uncertainty concerning the evidence required: "How were the waters and bottom of the lake occupied and by whom? Was it by fishing and as a highway over the surface or by what acts?" ${ }^{287}$ Legal and evidential indeterminacy prevailed.

In his notes prepared for argument in Tamihana Korokai, Salmond stated that the "Native Land Court has nothing to do with technical rules of English law and no jurisdiction to apply such rules to the customs and usages of the Natives". ${ }^{288}$ Salmond, the established jurist, was certainly familiar with Romanistic legal sources and the English common law. The presumption of usque ad medium filum aquae, which was "an artificial and technical rule of law imported into the Common Law from the Civil Law", could not have any application to Māori customs and usages. Salmond did not pause to contemplate the degree to which the complicated interaction of the Native Land Court with the Māori populations in various proceedings might have generated a re-shaping of such conceptions of "custom" at law, especially in circumstances where novel questions regarding custom and usages and proprietary interests might be posed for certain landscapes, including inland waters and the foreshore. Salmond's approach implied, somewhat mechanistically and hopefully, the recovery of ancient "customs and usages" somehow unaffected by (or insulated from) the incoming common law in judicial forums, such as the Native Land Court, or in the arguments of professional legal representatives trained in English common law. Salmond was concerned with the pleading in the statement of claim in Tamihana Korokai that the customary proprietors with parcels having a frontage upon Lake Rotorua became owners of the bed to its centre point by virtue of the operation of the presumption of usque ad medium filum aquae and the Native Land Act 1894, by which "customary land" status was transformed into freehold status. Paragraph 25(a) of the special case stated, pursuant to rule 245 in those proceedings, claimed that "the bed of the Lake or some part thereof is land held in freehold tenure by those Natives as accessory to their freehold title to land adjoining the bed and is included by implication of law in the Native Land Court Certificates of Title which have been issued as aforesaid and in the freehold titles obtained by virtue of these Certificates of Title". ${ }^{289}$ This argument was run in Tamihana Korokai. The counter-argument for Salmond would be that the "certificates of title [were] in themselves not grants at all but mere judicial declarations of the existence of customary title", with the qualification that, "[t]hey gave no freehold title until 1894". ${ }^{290}$ As such, titles fronting the lake could not "extend further than the land

286 Ibid.

287 Ibid.

288 "Rotorua Case Notes", typescript (1912) Crown Law Office Case 84, 2.

289 Refer to "Special Case Stated pursuant to Rule 245" at 13, Crown Law Office Case 84, Wellington.

290 "Sir John Salmond's argument as to the applicability of the ad medium filum presumption in connection with Lake Rotorua", typescript, Crown Law Office Case 84, Wellington (emphasis in original). 
where the title is actually investigated [-] the bed of the lake was never investigated." 291 Earl repeated the argument in the Native Land Court in 1918. He also cited the cases of Bristow $v$ Cormican ${ }^{292}$ and Johnston $v O^{\prime}$ Neill $^{293}$ in support of the common law proposition that riparian owners along lakes might have ad medium filum rights to lakebeds. ${ }^{294}$

At this remove it is difficult to determine to what extent Earl's tactical move to use ad medium filum, specifically informed by imported English and imperial common law sources, constituted a core part in the legal presentation of the case to which Earl subsequently fastened the oral testimony of his witnesses from various hapu of Te Arawa dwelling within the vicinity of the two lakes. Conversely, it remains complicated to assess whether the pre-litigation views of these witnesses would have indeed aligned so neatly and comfortably with the common law presumption of usque ad medium filum aquae and the conception of proprietorship in submerged land, which it necessarily entails. As at 1918, it is not evident to what extent the two streams of perspective might have been actively entwined, or whether the availability of congenial common law authority influenced the presentation not only of legal argument but also of evidence, as the preferred legal stance of the operational public service departments and the Crown Law Office did so for "the Crown". It remains unclear whether this form of engagement with the court's peculiar practices was viewed as unpalatable or alien to the observer's gaze but as a process to be tolerated and gone through nevertheless. Alternatively, it is difficult to ascertain whether the processes and vocabulary of the Native Land Court were considered sufficiently familiar and even somewhat useful to some, if not necessarily all, of the Te Arawa participants in 1918 that it could be regarded as a part of a dynamic customary milieu, appropriated, modified and translated into novel forms of interpretation through ongoing interaction with the court and representatives of government. The evidence, such as it is, would suggest the reasonableness of the latter interpretation. ${ }^{295}$ The Court had been operating in the vicinity of the lakes since at least 1881. It was not an unknown creature. Interaction with the processes of the Court encouraged the construction of certain ways of seeing and explaining the landscape (whether featuring water or not), as reflected in discussions before the Native Land Court in relation to what Salmond would perceive as local "custom". That is, the processes of the Native

291 Ibid (emphasis in original).

292 Bristow v Cormican (1878) 3 App Cas 641.

293 Johnston v O'Neill [1911] AC 552.

294 "Lake Rotorua Case 1918, Evidence", CL174/1, fos.98-106, Archives New Zealand, Wellington.

295 There is of course an ongoing debate concerning the historiography (such as it is) of the Native Land Court in the context of contemporary claims before the Waitangi Tribunal. See Grant Young "A Short History of Post-Treaty Māori Custom Relating to Land" and Michael Belgrave "The Tribunal and the Past: Taking a Roundabout Path to a New History" in M Belgrave, M Kawharu and David Williams (eds) Waitangi Revisited: Perspectives on the Treaty of Waitangi (Oxford University Press, Melbourne, 2005); and Lyndsay Head Land, Authority and the Forgetting of Being in Early Colonial Māori History (PhD Thesis, University of Canterbury, 2006) 105-130, for instance. 
Land Court and the modalities of speaking in that forum, as well as the identity and nature of issues (claims to land as "customary") could be seen, over time, as increasingly localised and "indigenised" to an extent if not completely. The statutory language generated a market in evidence on custom about ties to the landscape described as proprietary (or potentially so).

Management of the claim against the Crown in the Native Land Court required a degree of legal and evidential co-ordination. Before the adjournment of the proceedings on 1 November 1918, Earl called two witnesses in addition to Mair: Wiremu Maihi ("William Marsh") Ereatara and Tieri Te Tikao (the original named plaintiff in the companion proceeding to Tamihana Korokai $v$ SolicitorGeneral). Both individuals had, for instance, provided evidence in Native Land Court proceedings before Judge Johnson in relation to the Rotoiti land block in the period from 25 July 1899 until 19 December $1900 .{ }^{296}$ Ereatara in that proceeding was recorded as saying of his own claims to land adjacent to the lake that his boundary began at "Ngakaho on the shore of Lake Rotoiti; thence it runs inland ...". 297 Quite clearly, the hapu witnesses presenting evidence on behalf of the applicants could recite the formula of so-called take or the basis of claims to space, whether in respect of submerged land or elsewhere. ${ }^{298}$ Hence, the transcript of the Native Land Court proceedings for Lake Rotorua and Lake Rotoiti in 1918 housed scattered references to the rather conventional categories of the underlying "customary" causes or take of claims to authority and proprietorship under consideration in the litigation ("land held by Māori"): "conquest", "occupation", and "gift". Tikao characterized the rights of Ngāti Pikiao to Rotoiti as based upon the take of "conquest". ${ }^{299}$ These classifications were not specifically tied to the personalised authority of a rangatira (or chieftain) but to narratives of the relevant collective descent group, such as hapū. One witness would present a variety of relevant grounds for claims to pre-eminence and something approximating to possessory "title" in the sense of exclusive possession.

The suspicion of legal counsel for the Crown in the "Lake Rotorua" proceedings, and certain of its official advisors, was that the witness evidence in support of the application of the presumption of usque ad medium filum aquae was contrived. Prendeville thought that the Presiding Judge had not unreservedly accepted the assertion of the applicants that Lake Rotorua was divided amongst several hapū. On 26 October 1918 he reported to Salmond that Gilbert Mair, a principal witness for

296 See Native Land Court, Maketu Minute Book 17, 294, 317, 331-332, 369-370 (Tieri Te Tikao) and Native Land Court, Maketu Minute Book 16, 198 (Wiremu Maihi Ereatara).

297 Ibid, 198.

298 This rather hardened form of language to describe fluid and complex "claims" is briefly considered in Grant Young, above n 295, 259-260. For an interesting critical account see Lyndsay Head "Land, Authority and the Forgetting of Being in Early Colonial Māori History", above n 295. Also see Hickford Making "Territorial Rights of the Natives", above n 94, chapter three (for the 1840s).

299 "Lake Rotorua Case 1918, Evidence" (1 November 1918) CL174/1, fos.322-323, Archives New Zealand, Wellington. 
the applicants and long-standing Pākehā resident in the vicinity, had "been most innocent in not knowing anything about the elaborate plan prepared for the case but the Judge laughed at his innocence". ${ }^{300}$ Prendeville advised that Mair, "proceeded to show how the lake was actually divided up between the Hapus [sic] and how the fishing in each division was held by the Hapu and no other Hapu could cross this division of the land in the lake except by the permission of the owners."301 The Crown Solicitor surmised that "in order to show how jealously they guarded their land in the lake they have to discredit the Tuhourangi - a hapū to the south of Rotorua township - Old Meta their chief gets uneasy under these slurs and may yet explode". ${ }^{302}$ Prendeville inclined to the view that the claim is clearly a ruse of the young generation for blackmail and they have worked up the old men under imaginary grievances". ${ }^{303}$ Tactically, Prendeville stated that the "trouble is to exercise the necessary patience to let them hang themselves". ${ }^{304}$ Under cross-examination by Prendeville on 30 October 1918, Mair did agree that the boundaries were "fishing boundaries" but added that "I said that they corresponded with the hinterland [boundaries of the hapū] generally speaking". ${ }^{305}$ Evidence regarding rahui in respect of the use of fisheries in the lakes constituted a part of his testimony. ${ }^{306} \mathrm{Mr}$ Keys, an official of the Native Department and Native Land Court recorded in his diary for 26 October 1918 that Judge Wilson had "talked to me [on 23 October 1918] for quite a long time about the case; and (rather a peculiar thing for a Judge to do) told me that the Natives' case was well established". ${ }^{307} \mathrm{He}$ also wrote that it "seems now that the Crown, in opposing the Maoris' claim, will rely to some extent of section 87 of 'The Native Land Act, 1909', and not only Wilson but also Earl, KC ... thinks this section will have a most important bearing". ${ }^{308}$

The claim to property in the lakebed was received as a capricious tactical move, representative of various inter-hapū and intra-hapū political preferences. Salmond suspected that the "Natives did not themselves claim to be the exclusive owners of Lake Rotorua and that they were not aware that they were the owners of this lake until Earl told them so". ${ }^{309}$ Keys noted on 26 October 1918 that

300 Prendeville, Crown Solicitor, to Salmond (26 October 1918) CL174/2, 1, Archives, New Zealand, Wellington.

301 Ibid.

302 Ibid (emphasis in original).

303 Ibid.

304 Ibid.

305 "Lake Rotorua Case 1918, Evidence" (30 October 1918) CL174/1, 263, Archives New Zealand, Wellington. 306 Ibid, 212-213.

307 B Keys papers (26 October 1918) Ms Papers 0407 (Micro-0724), ATL, Wellington.

308 Ibid.

309 Salmond, to Prendeville, Crown Solicitor (24 October 1918) at 4, CL174/2, Archives, New Zealand, Wellington. 
"Mair is giving evidence at present, and Judge Wilson allows him the most extraordinary privilege of frequently explaining to the Maoris in Court what evidence he is giving, and even of receiving hints and reminders from them". ${ }^{310}$ In the presentation of the applicants' case on Lake Rotorua and Lake Rotoiti, repeated references were made to extracts from the minute books of earlier Native Land Court proceedings on the blocks of land surrounding the lakes. ${ }^{311}$ A number of witnesses had participated in earlier Native Land Court proceedings dealing with parcels of land bordering upon or in the vicinity of the lakes. For certain members of Te Arawa, then, the court located in the Waiariki district (based in Rotorua) and its processes would have had a degree of familiarity. The Presiding Judge generally dwelt within the locality. The issues before the court provided a construct in the formal contested space or site of legal proceedings through which the oral testimony and legal submissions would pass. Because the proceedings were contested, there was an oppositional format for the presentation of evidence argument. Counsel prepared pairs of opposed law speeches or submissions. Earl got to deliver his version.

Salmond received extensive correspondence from the Crown Solicitor, Prendeville, describing the thread of Earl's argument in the Native Land Court at Rotorua. Hawthorne and Knight of the Department of Lands and Survey also ensured that a reporter was contracted to transcribe the proceedings of each day in preparation for the production of a typescript account. ${ }^{312}$ To this end, Hawthorne associated this technique with providing tactical space for the Crown Law Office to consider its response to the applicants' case in the Native Land Court in as reflective a fashion as possible. The transcribed reports would be mailed to Salmond in Wellington and would eventually

310 B Keys papers (26 October 1918) Ms Papers 0407 (Micro-0724), ATL. He also recorded that "Mair's evidence, in English, is not interpreted to the Maoris, and his little speeches, in Maori, remain unexplained to the Counsel engaged, none of whom know Maori. The proceedings are being taken down in shorthand, and Wilson allows the drafts to be titivated and polished up before the final copies are typed off. Mair freely corrects the reports of his evidence, and even adds great pieces here and there - where he has omitted or forgotten something in Court. The whole conduct of the case is irregular, but no one seems to mind." I am indebted to Dr Ashley Gould for bringing this reference to my attention.

311 "Lake Rotorua Case 1918, Evidence", 30 October 1918, CL174/1, Archives New Zealand, Wellington.

312 See Hawthorne, Department of Lands and Survey, to Prendeville Crown Solicitor (5 October 1918) CL174/2, 2, Archives New Zealand, Wellington: "After a good deal of thought and conversation on the matter, it seems to me that the best tactic to adopt in this case is to listen to the evidence given in Court by the native side and then ask for an adjournment to enable the Crown to prepare its reply. Knight has arranged for a good man to take the evidence in shorthand and he and I arranged yesterday for the evidence to be transcribed in half-daily shifts, so that the morning's evidence will be typed by the following afternoon or evening and the afternoon evidence the following morning. This arrangement may perhaps render an adjournment unnecessary, as w[oul]d be able to go through the evidence each evening and be more or less prepared to deal with it at the end of the natives' case. But I think it w[oul]d be better to get an adjournment if the nature of the natives' contentions is such as to make it desirable for Sir John to review their evidence before the reply of the Crown is given". Prendeville had written in the margin alongside this final statement: "yes if necessary". 
be bound as a volume in the Crown Law Office. ${ }^{313}$ The logistical commitment illustrated the earnestness with which the Crown case was conducted before the Native Land Court. The service was made available to the Native Land Court itself and the applicant parties in the Rotorua hearing. Although the recording personnel changed in the course of the hearing on account of dissatisfaction with the quality of performance, the service remained active throughout the ten days the Native Land Court sat until the adjournment on 1 November 1918. ${ }^{314}$ It was intended that Salmond would deliver legal submissions for the Crown but the proceedings were adjourned on Friday, 1 November 1918 and never re-convened on 4 December 1918, as was initially envisaged at the time of adjournment. The judge died in the notorious influenza epidemic of that year whilst Prendeville himself was afflicted, as was Hawthorne. Prendeville advised Earl on 27 November 1918 that he did not expect to be fit for the continuation of the litigation. ${ }^{315}$ Prendeville wrote to Earl on 5 February 1919 seeking his agreement to an approach to the Chief Judge of the Native Land Court to arrange for a special fixture on a date "after the end of March". ${ }^{316}$ He confessed that, "As one or more of our staff will in turn be away on leave from now till the end of March it will be difficult for me to get back to Rotorua before April". ${ }^{317}$ There were delays to the re-commencement of the proceedings, both deliberate and otherwise. The interests of Ngāti Pikiao, a group within the Te Arawa confederation based in the vicinity of Lake Rotoiti, were increasingly thrust into the theatre of the negotiations concerning the re-activation of the proceedings. Tai Mitchell of Ngāti Te Takinga, a hapū of Ngāti Pikiao, sought to delay the resumption of the hearing. He was mindful of awaiting the results of the general election in 1919. Mitchell said to the Department of Lands and Survey official Knight, that, "If the present party I mean Massey's party is defeated and the liberal party gains the reins of Government I am very confident of a settlement being arrived at satisfactory to the Crown and the Natives." ${ }^{318}$ It was proposed, "therefore that I move at this end for the case not to be proceeded with prior to the General Election ...". ${ }^{319}$ The Liberal Party did not, however, return to the Treasury benches. Tactical motivations were in play on all sides of the argument. As we shall see, Salmond's conception or that of the Crown Law Office under his leadership eventually prevailed in legislation addressing the "Arawa district lakes" in 1922.

313 That volume is entitled "Lake Rotorua Case 1918, Evidence", and is identified in the archival collection as CL174/1, Archives New Zealand, Wellington.

314 The Native Land Court sat in hearing on Wednesday, 16 October 1918, 17 October 1918, 18 October 1918, Wednesday, 23 October 1918, 24 October 1918, 25 October 1918, Tuesday, 29 October 1918, 30 October 1918, 31 October 1918 and 1 November 1918.

315 Prendeville, Crown Solicitor, to Earl (27 November 1918) CL174/2, Archives New Zealand, Wellington.

316 Prendeville, Crown Solicitor to Earl (5 February 1919) CL174/2, Archives New Zealand, Wellington.

317 Ibid.

318 Mitchell to Knight (9 June 1919) CL174/2, Archives New Zealand, Wellington.

319 Ibid. 
The Native Land Court was understood to have "exclusive jurisdiction to investigate the title to customary land, to ascertain the relative shares of the owners, and to issue orders called "freehold orders", which [would] have the same effect as a Crown grant transforming that land into Native freehold land and vesting it for a legal estate in fee simple". ${ }^{320}$ Section 92 of the Native Land Act 1909 provided that on any investigation and determination of title to customary land, the Native Land Court would make a "freehold order" defining the area dealt with, naming the persons entitled to the area and specifying their relative interests in the land. Every "freehold order" would have the legal effect of vesting a legal estate in fee simple in possession in the named persons. Salmond was aware that the Native Land Act 1894 provided that all land still held under a certificate of title or under a memorial of ownership in respect of customary land as at the enactment of the 1894 statute would become subject to the Land Transfer Act system and in consequence the owners would acquire an indefeasible legal estate in fee simple. ${ }^{321}$ Treating the phrase "native title" in these circumstances as an analogue for statutorily recognised "customary land" within the meaning of section 2 of the Native Land Act 1909, the Crown Law Office under Salmond was prepared to argue the view that "native title" was "not universal". 322 "If no claimant can prove his title it is not Native land at all." 323 The sense was that the applicant would bear a probative onus to establish evidentially that the submerged land, otherwise vested in the Crown as its dominium, ${ }^{324}$ was "held ... under the customs and usages of the Māori people" in view of Salmond's perception of the legislative definition of "customary land".

On Salmond's account in 1918 (as in 1912-1914), only forms of Māori engagement with land comparable to proprietorship (or, in other words, legally and evidentially worthy of a finding

320 See Salmond, explanatory memorandum, "The Native Land Act 1909: Introduction (Memorandum by the Solicitor-General)", in The Native Land Act, 1909 (issued at the direction of the Hon James Carroll, Native Minister) (Wellington, 1910) xi (Parliamentary Library, Wellington).

321 A "memorial of ownership" described the form under section 47 of the Native Land Act 1873 that declared "the names of all persons" found to be "owners" of "customary land". The nomenclature of "certificate of title" was used in substitution for "memorial of ownership", for example, in the Native Land Court Act 1880 .

322 Crown Law Office, argument, "Rotorua Case" undated, 1918(?), CL174/2, at Archives New Zealand, Wellington. In terms of relative accessibility, a copy of this argument was reproduced in Boast, above n 4, 77-82.

323 Ibid.

324 The Romanistic legal term dominium was employed by Salmond but in a sense that differed from the conventional use of this term in Roman law. As Frame has noted in Southern Jurist, above n 1, 124-125, it was apparently used by Salmond in a marginal handwritten note on the transcript of the "Lake Rotorua" proceeding in the Native Land Court in 1918. It did not, however, materialise in an outline of his theory of imperium and dominium until the sixth edition of his Jurisprudence: or the Theory of the Law (6 ed, Sweet and Maxwell Limited, London, 1920) when he added, as Appendix V, a section on "The Territory of the State" (see Salmond's preface to this edition). 
tantamount to "rights of ownership") could properly form the subject of a freehold order. Where the evidence signified less than a relationship of "ownership", then a finding of non-territorial rights might be appropriate. "Ownership", according to the Crown argument prepared for the Rotorua Lakes case, involved "exclusive possession and use for all purposes". ${ }^{325}$ The proposed submission stated that, "[f]ishing rights and navigation rights are different from rights of ownership". ${ }^{326}$ Salmond described the relevant concept of "ownership" in a letter of 24 October 1918 to the Crown solicitor representing the Crown in the Native Land Court in Rotorua, James Prendeville. "By a right of ownership", said Salmond, "is meant a right vested in defined persons to the occupation of the land to the exclusion of all other persons and to the use of the land for all persons". ${ }^{327}$ In this vein, according to the Solicitor-General, "Any right less than this and any non-exclusive right is not ownership". ${ }^{328}$ Salmond was certainly disappointed at the paucity of evidence on "public user". Yet, in this private correspondence, Salmond insisted that it was "not disputed by the Crown that the Natives have and always have had rights of fishing and navigation, in Rotorua and other inland lakes and waters". ${ }^{329}$ Furthermore, the Crown did not claim that the "public by prescription, grant or otherwise have obtained any legal right of navigation or fishery in such waters". ${ }^{330} \mathrm{He}$ confirmed that, "What is contended by the Crown is that these rights are rights of user only and not rights of exclusive ownership such as exist in respect of dry land and that therefore they cannot be made the foundation of a freehold order". ${ }^{331}$ Elsewhere, he admitted that it could not "possibly be contended on behalf of the Crown that Native customary title is limited to dry land and does not include waters". ${ }^{332}$ Yet, he said that: ${ }^{333}$

I should like to prove for example that all Tribes around Lake Rotorua have equal right of navigation over the whole Lake, but that rights of fishery are localised [-] distinct fishing grounds being appropriated to particular Hapus sub-Tribes or families.

325 Crown Law Office, argument, "Rotorua Case" undated, 1918(?), CL174/2, 4, Archives New Zealand, Wellington.

326 Ibid.

327 Salmond to Prendeville (24 October 1918) CL174/2, 2, Archives New Zealand, Wellington.

328 Ibid, 4.

329 Ibid, 1.

330 Ibid.

331 Ibid.

332 Salmond to Under-secretary of Lands, "Lakes Rotorua and Waikaremoana" (11 June 1917) CL174/2, Archives New Zealand, Wellington.

333 Salmond to Prendeville (24 October 1918) CL174/2, at 2, Archives New Zealand, Wellington. 
Counsel for the applicants anticipated this line of argument. In his examination-in-chief of Ereatara on 1 November 1918 in the Native Land Court hearing of the "Rotorua Lakes case", Earl enquired, rather leadingly, whether each hapū exclusively possessed, as a matter of fact, its particular division of Lake Rotorua. The witness responded affirmatively that it was indeed "exclusive possession". According to Ereatara, "If a hapu were seen rowing over another hapu's subdivision questions would be asked as to why they were rowing over it". 334 He continued with the comment that, "If it were found that they were going over it for the purpose of working or laying claim to it the result would be a fight". ${ }^{335}$ The importance of affiliation to a certain descent group for particular purposes and at certain times was identified with Ereatara stating, "the only time they are allowed to go over these subdivisions is when, say Ngatirangiwewehi were going over the Ngatiwhakaue portion as a Ngatiwhakaue, or vice versa". ${ }^{336}$ When queried about the degree to which hapū had historically accommodated the presence of Pākehā strangers in the area of Lake Rotorua and Lake Rotoiti, Ereatara replied that the "Maoris made no objection to them going over the lake, because the Maoris thought they came here just for the purposes of sight-seeing, and to see the lake". ${ }^{337}$ Earl also sought to rely upon the recent practice of elements of the Crown to acquire (through purchase) parcels of land that included lakes in the vicinity of the settlement at Rotorua. One illustration was Lake Opouri (or Ngāpouri). In addition Prendeville advised Salmond that several lakes (including Ōkataina, Ōkareka, and Rotokakahi) had formed parts of blocks already subject to orders of the Native Land Court. Salmond, however, cautioned Prendeville against accepting this as having any significance. "These purchases", said Salmond, "were the purchases of all Native rights over the locus in quo irrespective of whether these rights were of ownership or rights of fisheries". ${ }^{338} \mathrm{He}$ regarded the former Native Land Court orders (and the recent Lake Waikaremoana order) embracing lakes as "immaterial" as the "very question now in issue is whether these orders were or were not properly made". ${ }^{339}$

\section{THE TREATY AS A SOURCE FOR UNDERSTANDING CLAIMS TO NATIVE TITLE RIGHTS}

The developing Crown Law Office approach to customary interests was not a perspective derived from the recognition of justiciable common law rights or even a specifically common-law source for according legal recognition to the property rights of Māori. In 1917 Salmond commented

334 "Lake Rotorua Case 1918, Evidence" (1 November 1918) CL174/1 at fo.309, Archives New Zealand, Wellington.

335 Ibid.

336 Ibid (emphasis added)

337 Ibid at fos.309-310.

338 Salmond to Prendeville (24 October 1918) 3, CL174/2, Archives New Zealand, Wellington.

339 Ibid, 4. 
that, "Native customary title depends for its existence on the Treaty of Waitangi as recognised and validated as a ground of legal title by the successive Acts dealing with Native land". ${ }^{340}$ In a critical passage, Salmond opined that the, "extent of Native title depends therefore on the true construction of that Treaty and of the validating legislation".341 "This", said the Solicitor-General, "depends on the expressed or implied intention of the grantor, namely the Crown and Parliament". ${ }^{342}$ Thus, in citing the favourable decision of Waipapakura $v$ Hempton in his 1917 legal opinion to the UnderSecretary of Lands, Salmond supposed that the "Supreme Court has held that it was not intended to include tidal waters", such as the "harbours, foreshores and tidal rivers of New Zealand". ${ }^{343}$ Salmond confessed that, "Neither the Treaty nor the statute contain any express exception of such waters but this exception has had to be implied on the ground that it would be unreasonable to presume an intention on the part of the Crown and the Legislature to destroy the public rights of navigation and access to the sea". ${ }^{344} \mathrm{He}$ analogised the implied constraint applied through the interpretative thread of the common law with that which applied to Crown grants pursuant to section 35 of the Crown Grants Act 1908: ${ }^{345}$

Just as a Crown grant described as bounded by the sea goes only to high water mark, so the statutory grant on which Native title depends has had the same implied limit imposed upon it.

"Even therefore", continued Salmond, 346

[I]f it could be proved that by Native custom the Wellington Harbour was the subject of exclusive private ownership, this customary ownership has acquired no legal recognition or validity and no freehold order could be obtained in respect of such waters.

This reflected a mature rendition of a Crown theory, as interpreted by the Solicitor-General, against the background of his experience with the drafting of the Native Land Act 1909 and his participation as senior counsel for the Crown in Tamihana Korokai in 1912 and Waipapakura v Hempton in 1914.

Here, then, was a strand of a legalistically expressed Crown idiom or register with interpretative consequences premised not upon common law sources but upon the articles of the Treaty of

340 Salmond, Solicitor-General, to Under-secretary of Lands (11 June 1917) CL174/2, 3, Archives New Zealand, Wellington.

341 Ibid.

342 Ibid.

343 Ibid.

344 Ibid.

345 Ibid.

346 Ibid. 
Waitangi and on divining the proper intention of the various legislative regimes that had specifically addressed "native land". This approach was entwined with assumptions concerning the common law protection of public rights (jus publicum), especially rights of navigation and fishing. As such, he concluded that "[t]his Treaty and legislation amounts in effect to a statutory grant from the Crown to the Natives and the question is what are the limits and bounds of this statutory grant". ${ }^{347}$ As counsel to the Law Drafting Office in 1909, Salmond stated that, "[c]ustomary land, since it has never been Crown-granted, belongs to the Crown". ${ }^{348}$ It accordingly fell, in his opinion, within the broad sense of "Crown land" as a term, ${ }^{349}$

[S] ubject, however, to the right of those natives who by virtue of Māori custom have a claim to it to obtain a Crown grant (or a certificate of title under the Land Transfer Act in lieu of Crown grant) on the ascertainment of their customary titles of the Native Land Court.

Hence the handwritten marginal note (attributed to Salmond) on the Crown Law Office's version of the transcribed record of Earl's oral argument before the Native Land Court in Rotorua on 16 October 1918: "[The Crown] acquired whole dominium subject to Native proved titles". ${ }^{350}$ This concise remark expressed part of the inner core of Salmond's theoretical and evidential approach. It was expressed in opposition to Earl's proposition that under the Treaty of Waitangi, "nothing passes to the Crown ... but the Sovereignty, no territory whatever, nothing of value, with the exception of the sovereignty under the Treaty". ${ }^{351}$ As such, the "Crown acquired no territorial title whatever, the Crown acquired nothing but what could be voluntarily ceded to the Crown or purchased." Indeed, "everything else so far as the North Island was concerned remains in the Natives". ${ }^{352}$ From the perspective of the Crown's official appreciation of the then accessible jurisprudence in the ordinary courts, such a suggestion would have been treated as an unwelcome novelty, although the correspondence internal to the Crown suggests that certain of its legal advisors and officials were not completely unfamiliar with the possibility of such a stance. Certainly, Hawthorne had anticipated that legal counsel for the applicants would adopt this line of presumed Māori ownership in the Native Land Court. Unsurprisingly, the risk of failure in the courts was acutely appreciated

347 Salmond, Solicitor-General, to Under-secretary of Lands (11 June 1917) CL174/2, 3, Archives New Zealand, Wellington.

348 Salmond, "Native Land Bill [1909]: Memorandum. Notes on the History of Native-land Legislation" No 873, Bill Books (1909) 1, Parliamentary Counsel Office, Wellington.

349 Ibid

350 "Lake Rotorua Case 1918, Evidence" (16 October 1918) CL174/1, at fo.22 (B.16), Archives New Zealand, Wellington. The script appears to be in the hand of Salmond in view of the contemporaneous handwritten correspondence (it does not seem to be in the hand of James Prendeville, Crown Solicitor, in any event). Frame in Salmond: Southern Jurist, above n 1, 124.

351 Ibid.

352 Ibid. 
even though the outcome was not perceived to be particularly palatable from a public policy standpoint.

In litigating the meaning of native land legislation, Salmond, resorted to a theory of the Crown as to the place of the Treaty of Waitangi and native title in relation to a conception of the "public interest", a notoriously fluid concept. In this vein, the legal intervention of the Crown could both reflect and escalate the perceived significance of certain proceedings, whether in the Native Land Court or the ordinary courts. The Crown's decision to contest the claims of members of certain Te Arawa hapū, in the "Rotorua Lakes case" in 1918, proved to be a case in point. The "public interest" was understood, in part, as connoting the concept of the jus publicum or ius publicum. In his capacity as a jurist, Salmond had described the jus publicum in the context of a specific legal maxim - privatorum conventio juri publico non derogat. ${ }^{353}$ Against this background, he cited the eastern Roman or Byzantine source the Digest or Pandects of the Emperor Justinian and opined that: 354

By jus publicum is here meant that part of the law which concerns the public interest, and which for this reason the agreements of private persons cannot be allowed to infringe upon.

In the Lakes proceedings, Salmond desired, "if possible to obtain a decision in favour of the Crown on the ground that the navigable waters of this country never did belong to the Natives". ${ }^{355}$ That is, the public law of the Crown would carve out a legal space (populated by public rights of navigation and fishery, for instance) that could not be touched by private law rights unless legislation granted otherwise. Crown proprietorship was perceived in policy and legal terms as a guarantor of such space against the possibility of localised non-Crown control of the relevant space. In 1914 Salmond also expressed concern to the Local Bills select committee that the vesting of additional tidal lands in the Auckland Harbour Board by local legislation would compromise the public rights of navigation and fishing, as well as recreational activities. Solicitors for the Auckland Harbour Board contested this opinion but the context is suggestive of Salmond's general approach. ${ }^{356}$ The denouement of the litigation in the "Rotorua Lakes case" also revealed the government's claims to sort out in the political realm when and where the Crown might be insulated from the consequences of undesirable court action. Frame has noted in passing the practical motivations underlying government's preference for dealing with Māori politically rather than

353 John Salmond Jurisprudence: or the Theory of the Law (Steven and Haynes, London, 1902) 384.

354 Ibid. In this specialized use of the concept of the jus publicum, Salmond said further that, "Agreements which in this way overpass the limits allowed by the law are said in a wide sense to be illegal, or to be void for illegality. They may or may not be illegal in a narrower sense, as amounting in their making or in their performance to a criminal and or civil wrong." See also Salmond Jurisprudence or the Theory of the Law (3 ed, Steven \& Haynes, London, 1910) 317.

355 Salmond to Prendeville (24 October 1918) CL174/2, 4, Archives New Zealand, Wellington.

356 Russell and Campbell to Secretary, Auckland Harbour Board (2 December 1914) M1 4/40, A4, Archives New Zealand, Wellington. 
judicially. ${ }^{357}$ Vitally, however, Salmond believed the law supplied a theoretical fillip to this approach on account of the Treaty as a source of claims to rights that might not be recognised (unless legislative recognition were accorded to those rights).

\section{A CROWN THEORY AND POLITICAL OUT-OF-COURT SETTLEMENT SECURED IN LEGISLATION}

The preferred legal register or vocabulary of the Crown on the Treaty of Waitangi, and customary rights, insofar as there was one, could be expressed in legislation and insulated from unwelcome litigation to an extent. If legislated, it would be secured in the non-litigated parts of governmental work for the life of the legislation or, more precisely, the life of the awareness and memory of the theory or perhaps theories amongst officials and politicians. That official awareness could be very ephemeral indeed, not least of all because the paper record of the day-to-day press of government policy and legal work is seldom reflective. It is often contested and is pulled in directions responsive to issues of the moment and the demands of policy. ${ }^{358}$ Salmond was evidently in earnest with his approach to developing what could be properly characterised as a Crown-based theory on the Treaty of Waitangi and the Māori land issue that could be applied consistently and could cast a measure of coherence across what might be referred to as governmental law. Having participated in the drafting of the Native Land Act 1909, he had already distilled a theoretical map of sorts to navigate the legislation, as revealed in his three memoranda accompanying the Bill as it proceeded through the legislature. ${ }^{359}$ In looking backwards at the case law and previous native land legislation, he was also, Janus-like, looking forwards and seeking to embed a degree of theoretical coherence and consistency to the government's legal approach. As the second (and non-political law officer $)^{360}$ he would have some traction. He did become familiar, nevertheless, with the conceptual and evidential vulnerability of the executive branch's preferred legal view vis-à-vis the class of "customary land" recognised statutorily under the Native Land Act 1909.

In 1922 Salmond's theory on the Treaty of Waitangi and the Crown's proprietary entitlement to large navigable lakes would persist in a particular piece of legislation expressing an out-of-court settlement on fourteen Arawa or Rotorua district lakes, including Rotorua, Rotoiti, Ōkareka,

357 Frame Salmond: Southern Jurist, above n 1, 114-115.

358 Assuming that the "register" or "theory" ever gets to be litigated, courts might not, of course, necessarily share the preferred official view of chosen words in any given piece of legislation.

359 Salmond "Native Land Bill [1909]: Memorandum: Notes on the History of Native-land Legislation", printed at the front of the Native Land Bill, 1909, Nos 87-1, 87-2 and 87-3, Bill Books, 1909, Parliamentary Counsel Office, Wellington.

360 On the legal role of the Solicitor-General, see J McGrath "Principles for Sharing Law Officer Power: The Role of the New Zealand Solicitor-General" (1998) 18 NZULR 197. 
Ōkataina, Tarawera, Rotomā, Ngāpouri (Opouri), and Rotomahana. ${ }^{361}$ Section 27 of the Native Land Amendment and Native Land Claims Adjustment Act 1922 "declared" the beds of the lakes, "together with right to use the waters of the said lakes, ... to be the property of the Crown, freed and discharged from the Native customary title, if any". ${ }^{362}$ There was, accordingly, an agreement to disagree as to the possibility of native title subsisting in the lakebeds. If any such title did exist, it was treated as extinguished at law by virtue of the particular form of the statutory vesting. The rights of the "natives" to "fish for and catch for their own use any indigenous fish in any of the said lakes" were "reserved" in section 27(2) of the statute. No such fish were to be sold, except with the consent of the Arawa District Trust Board constituted under section 27(4) of the legislation.

On 12 May 1920, the Minister of Lands, D G Guthrie, instructed Prendeville, then based at the Crown Law Office in Wellington, to explore the possibility of a negotiated settlement with the "Natives interested". The Minister indicated that he would be prepared to "agree to granting free fishing rights to the Natives without license [sic], or interference by Rangers, provided that the fish is used for their own consumption and is not sold, and provided also that it is not taken out of season". ${ }^{363}$ As for title, the relevant members of Te Arawa would "abandon their claims to the bed of the Lake, admitting the Crown's title to the same subject to any fishing rights reserved in the Treaty of Waitangi". Subsequently, on 22 May 1920, Guthrie would telegram Ngata, acting as one of the principal negotiators for the political and legal settlement of the lakes claim, that "the only basis of negotiation for settlement could be that the right to the bed of the lakes is sufficiently doubtful both to claimants and Crown as to be subject of reasonable compromise". ${ }^{364}$ The AttorneyGeneral, Francis Bell, had advised Cabinet in a memorandum of 21 March 1922 that he was, "confident of the law if the point could be decided by a Court of Law", as opposed to the Native Land Court. ${ }^{365}$ Bell observed that, "[b]y the Treaty of Waitangi the whole fee simple of the lands of New Zealand became vested in the Crown, subject to the Native right". ${ }^{366}$ In Bell's account, "[t]he

361 I do not examine the negotiations in detail here although I believe that they still require a careful history. For accounts to date see: White, "Inland Waterways: Lakes"; Tania Thompson "Interim Report - Rotorua Lakes Research" (5 March 1993) report for O'Sullivan Clemens Briscoe and Hughes (held by the Office of Treaty Settlements, Wellington); "Rotorua Lakes Report" Research Unit, Manatū Māori, Wellington, February 1990. These last two reports are referred to in White.

362 Emphasis added.

363 D G Guthrie, Minister of Lands, to Prendeville, Crown Solicitor, Crown Law Office (12 May 1920) CL174/2, Archives New Zealand, Wellington.

364 Guthrie to Ngata (22 May 1920) ABWN 8925 W5278 Box 76226.5 pt b, Archives New Zealand, Wellington.

365 Bell, memorandum for Cabinet, "separate and strictly confidential", 21 March 1922, MA1 W2459, box 49, 5/13/242 pt 4, Archives New Zealand, Wellington. This memorandum can be located in the Department of Native Affairs file referred to along with several of John Salmond's opinions, including Salmond to Attorney-General (4 November 1912).

366 Ibid. 
Native right in respect of those waters [the beds of the so-called Arawa district lakes] was the exclusive user by certain tribes and hapus [sic], but as in the case of the shores of the sea and the navigable rivers of New Zealand, the bed of the waters was in no sense vested in the tribes and hapus [sic], which have the rights over the waters". ${ }^{367}$

As with Salmond, Bell was concerned that, "[t]he contrary view confuses the question of the Māori rights, which is a matter of custom determinable by the Native Land Court, with the legal result in England of ownership of fishing rights and marginal occupation". $368 \mathrm{He}$ advised his ministerial colleagues that the "Supreme Court [sic; the Court of Appeal in Tamihana Korokai v Solicitor-General] has decided that the question of the ownership of the bed of the Lakes is a question for the Native Land Court". ${ }^{369}$ In consequence, the Attorney-General averred that the question of proprietorship of inland waters was, "not to be determined as a matter of law which lawyers could advise upon, but as a matter which the Native Land Court can determine absolutely subject only to the Native Appellate Court". ${ }^{370}$ Given that the specialist court of first instance on Māori "customary land" would have pronounced on evidence, Bell considered it "improbable", and therefore imprudent, to rely upon the possibility of the Privy Council reversing "the decision of the Native Appellate Court on the question of the extent of Native rights under the Treaty of Waitangi". ${ }^{371}$ With a view to persuading Cabinet to accept a settlement with representatives of Te Arawa, Bell was aware that the recent decision of Judge Gilfedder in the Native Land Court concerning Lake Waikaremoana had favoured the finding of a lake bed as customary land. $\mathrm{He}$ regarded the Waikaremoana precedent as "extremely serious", as "the result of granting the fee simple of the bed to the Natives would raise very serious question[s] as to the right to withdraw water from the lake for electrical power purposes". ${ }^{372}$ Because it was a specific instance, the theory was treated as applying in a particular politically negotiated space rather than generically throughout New Zealand although the Crown "register" would continue to apply as the executive branch's internal interpretative view as to the content of the pertinent law. ${ }^{373}$

367 Ibid.
368 Ibid.
369 Ibid.
370 Ibid.
371 Ibid.
372 Ibid.
373 Further careful legal historical work is required to chart its subsequent course and any changes to it over
time. 


\section{CONCLUSION - TOWARDS WRITING CONSTITUTIONAL HISTORIES OF THE CROWN AND THE TREATY OF WAITANGI}

This study has charted the nuances of a Crown legal "register", language or way of speaking about the Treaty of Waitangi and "native title" during the service of Salmond as Solicitor-General. It has revealed a complex approach to "native title" and the Treaty of Waitangi and its contested place within public law and inside the Crown itself. It has done so through examining the documentary record internal to government, especially the interaction between departments in the response to litigation on native land questions. Importantly, this essay illuminates the possibilities of exploring a constitutional history of the Treaty internal to the Crown, as much as one external to it. Within the Crown, the Treaty of Waitangi was seen as the political source for Māori claims to the legal recognition of rights in statutory regimes (such as the Fisheries Act 1908 or the native land legislation). Salmond saw customary native title as a mere normative claim (rather than a legally actionable right) arising under the Treaty of Waitangi. It was a claim to have a Crown grant issue in particular circumstances and recognised in legislation. English common law sources were used to constrain the interpretative scope and practical reach of the Treaty of Waitangi. These common law sources would also outline the specific circumstances that would yield a judicial finding in favour of customary land status and a subsequent Crown grant. Tidal waters, for instance, were precluded from the recognised scope of a claim to customary title under the Treaty. The common law, however, was not viewed as supplying the ordinary courts with power to determine whether land (submerged or otherwise) was subject to native title. The claims to such interests were construed as Treaty-based claims tied to a specific statutory structure and a specialist Native Land Court. The ordinary courts might consider whether customary fisheries were recognised statutorily but the Native Land Court enjoyed exclusive jurisdiction on "native land". In 1922, in the wake of the politically negotiated compromise of litigation, legislation was used to secure a preferred legal position of the Crown in relation to navigable lakes and to insulate it from further litigation. Salmond's legal stance provided a theoretical as much as a pragmatic foundation for this sort of arrangement. Furthermore, his approach expressly introduced the analytical conception of territorial and non-territorial rights to New Zealand (with customary fishing rights under the fisheries legislation being construed as "non-territorial") but these categories would be subjected to different perspectives in the nascent scholarship of Paul McHugh in 1984 and in the decision of Te Weehi in 1986.

While approaching the question of a Crown "register" or language via Salmond and the Crown Law Office, the argument has sought to present the understanding and production of views on public law within the Crown as part of a complex interaction amongst departments and Ministers themselves. By isolating a strand of legal reasoning and language within the Crown, mapping its actual deployment in litigation and in discussions both internal and external to the executive branch of government, this article has revealed a distinctive and sophisticated set of voices and conversations that suffuse a part of New Zealand's past. 